\title{
Urban adolescents needs assessment survey in Bangladesh
}

\section{Sajeda Amin}

Population Council

Follow this and additional works at: https://knowledgecommons.popcouncil.org/departments_sbsr-pgy

Part of the Demography, Population, and Ecology Commons, Family, Life Course, and Society Commons, and the International Public Health Commons How does access to this work benefit you? Let us know!

\section{Recommended Citation}

Amin, Sajeda. 2015. "Urban adolescents needs assessment survey in Bangladesh." Dhaka: BIED, BRACU, and Population Council. 

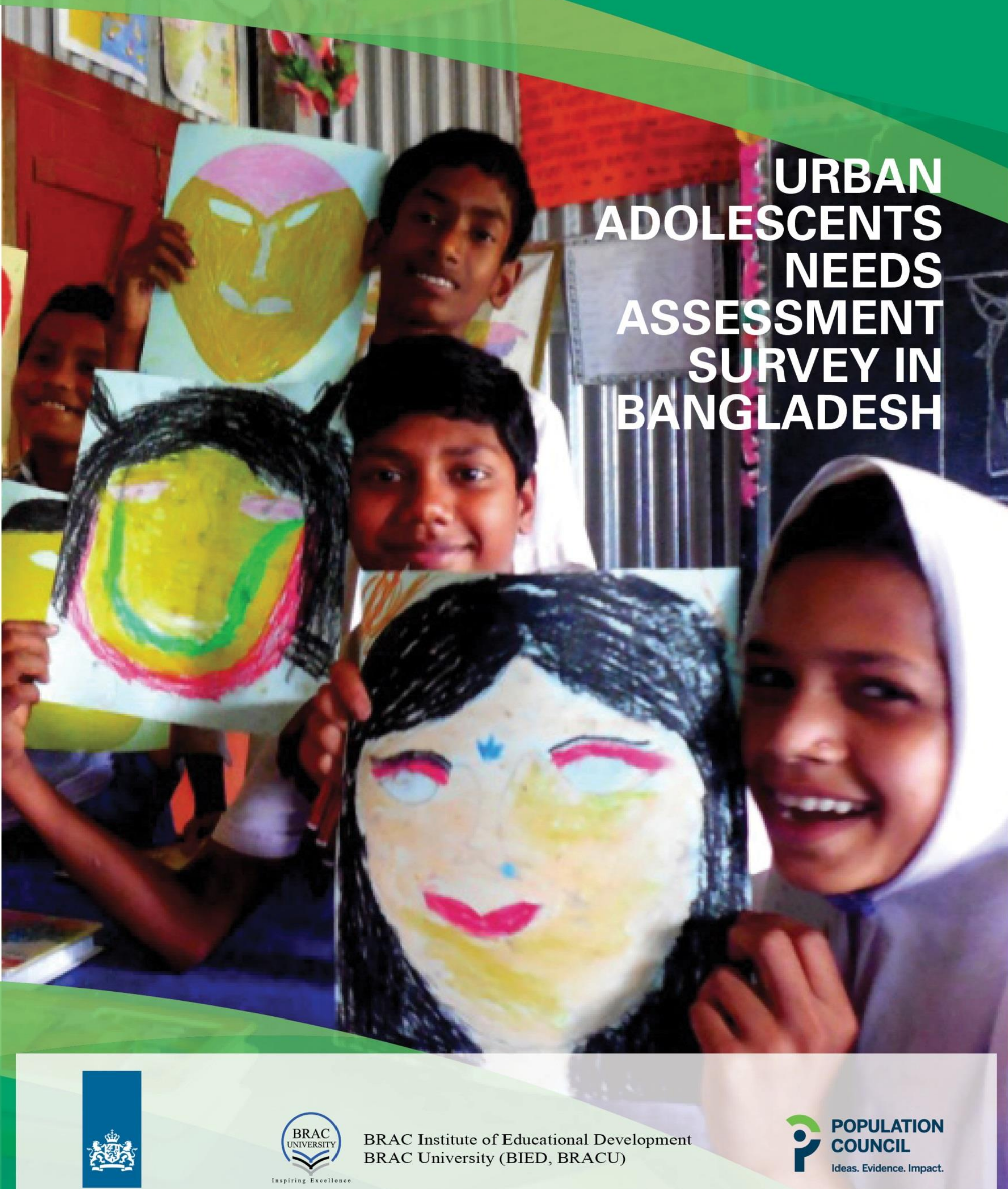

BRAC Institute of Educational Development BRAC University (BIED, BRACU)

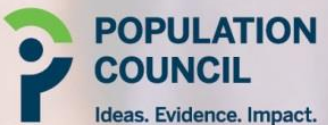

Embassy of the 


\section{Table of Contents}

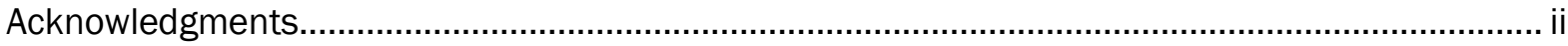





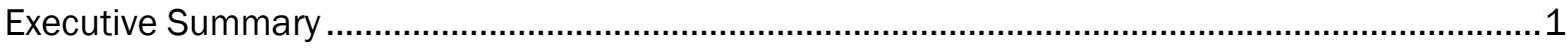

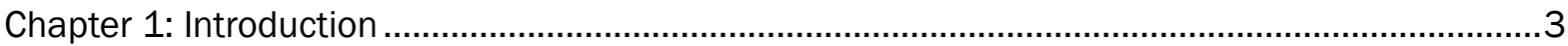
Nashida Ahmed

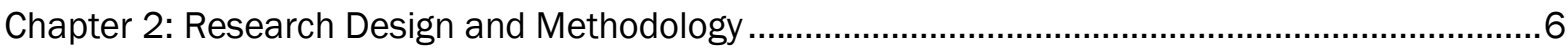
Md. Abul Kalam and Sigma Ainul


Md. Abul Kalam

Chapter 4: Sexual and Reproductive Health, Marriage, and Childbearing.................................. 35 Mitul Dutta, Syeda Rezwana Akhter, and Shuchi Karim

Chapter 5: Mobility, Violence, Social Interactions, and Gender Norms ..................................... 43 Shuchi Karim and Muhammed Mamunur Rashid


Jyotirmoy Saha and Shakila Yesmin

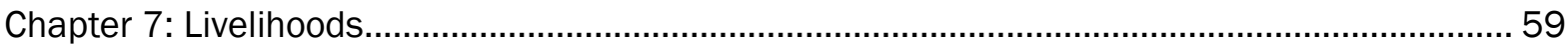
Md. Abul Kalam

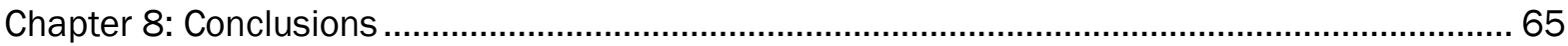
Sajeda Amin

References 68 


\section{Acknowledgments}

The Population Council collaborated with BRAC Institute for Educational Development, BRAC University (BIED, BRACU) on a research program to generate evidence on the status of urban adolescents in Bangladesh. This report is part of that program and presents evidence from a sample survey conducted in Dhaka North, Dhaka South, and Gazipur districts in Bangladesh. We are grateful to the Embassy of the Kingdom of the Netherlands (EKN) in Bangladesh for their generous support. Key members of the EKN team included Ella de Voogd, First Secretary, Sexual and Reproductive Health and Rights, and Mushfiqua Z. Satiar, Advisor-SRHR. We thank Dr. Erum Mariam, Director, BIED, BRACU, for initiating the research, formulating goals and ideas, and developing the research concept note.

The authors wish to acknowledge the contributions of the many individuals and institutions that made this research possible. We thank the field and data management teams of BIED, BRACU for their work on the adolescent household survey. Mamun-Ur-Rashid and Mahmudulla Sarker provided overall field support and supervision. Areefa Zafar was responsible for financial management and for communicating with Population Council USA. Dr. Shuchi Karim, Nashida Ahmed, Md. Abul Kalam, Hamida Akhter Zahan, Sarah Tabassum, Tawheed Rahim, Ashfi Mehnaz, Ratna Guha, Dilruba Begum, Shakil Ahmed, Shahana Akter, Puja Gloria Rodrigues, Sadia Ritu, and Mesbah Uddin of BIED, BRACU jointly developed the questionnaire in collaboration with the Population Council. Basabi Maksud and Varati Rani Roy provided logistical and other support. Sheikh Shahana Shimu and Mrinal Krisna Das assisted in questionnaire formatting,

Dr. Muhammad Kabir served as a consultant and provided technical input on sampling strategy and site selection for the study. Sigma Ainul of the Population Council was responsible for overall coordination and for communication with BIED, BRACU on study design and implementation, and led the literature review. Jyotirmoy Saha performed data quality checks and statistical analysis. Anonymous reviewers at the Population Council's Institutional Review Board reviewed and approved this project and provided ethical clearance. A warm thank you also goes to Population Council colleagues who made important contributions to this study and report. Sarah Engebretsen and Ann Blanc reviewed the report and offered valuable input. We thank Dipak Kumar Shil and Mamunur Rashid of the Dhaka office. Finally, a special thank you goes to the adolescent girls and boys in eight upazilas who shared their experiences and perspectives with us, without whom this study would not be possible. 


\section{Foreword}

The present study, "Urban Adolescents Needs Assessment Survey in Bangladesh," provides an overview of the experiences of adolescents living in urban settings. BIED, BRACU undertook this study as part of a broader needs assessment to inform several urban adolescent programs. Through this study we seek to inform our work to improve educational outcomes, provide better access to sexual and reproductive health information, and support those in need of counseling and mental health services.

The findings will have implications for BIED, BRACU's existing and future program strategies for promoting adolescent well-being. The findings will affect testing, finalizing, measuring impact, and expanding/replicating BIED, BRACU's urban-centered low-cost junior secondary education model (SSCOPE), which integrates academic learning; gender, sexuality education, mental health education; and provisions for trusted psychosocial support/counseling services and the establishment of "frontline counselors" (shomaj shongees).

BRAC is committed to serving the most disadvantaged populations in the most challenging settings. The urban poor are increasingly recognized as belonging to this category. Children and adolescents are among the most vulnerable members of any community and disproportionately suffer the negative effects of poverty and inequality. Development practitioners realize that standard programming approaches, which focus on extending services to more readily accessible communities, do not always reach those people whose needs are the greatest. Fostering equity in urban settings must be the guiding principles in all efforts to secure the rights of adolescents in those areas. The adolescents of slums-born into and raised under some of the most challenging conditions of poverty and disadvantage-require particular attention in order to improve their circumstances.

Despite slum dwellers' proximity to metropolitan areas where basic services are available, access is often denied. The World Bank offers a number of reasons why slum populations have less access to education, which include high cost, high opportunity costs of education, and distance to school-among others. It is time to accept this new paradigm and to start investing in human capital development in the slums of Bangladesh (UNICEF 2010). Cameron (2011) emphasizes the need for a greater focus on education for the urban poor, particularly for people living in urban slums because they lack wealth, power, and social connections; they are often undercounted in national surveys, and they are underserved by both government and nongovernment organizations, many of whom still see poverty as a rural issue or see the urban poor as less deserving of help.

BIED, BRACU is establishing frontline counselors for BRAC's Adolescent Development Program (ADP) and Urban Street Children Project to deliver sexuality education among adolescents. We are in the process of developing, piloting, and finalizing a standardized curriculum for mental health frontline counselors, to build their skills as helpline counselors and to provide a diploma and masters course on counseling. Finally, BIED, BRACU is designing three technical labs: a) designing lab for producing user-friendly learning materials for Early Childhood Development (ECD)-primary and secondary schoolgoers; b) Center for Psychosocial Support to facilitate BIED's internal work related to capacity-building and research for primary-age children and adolescents as well as provision of counseling services for adult external stakeholders; and c) Center for Play and Arts (visual and performing arts), which will have connections to the Psychosocial center. The research findings will provide evidence and support for all these interventions to introduce actions that respond to the priorities of adolescents' needs. Additionally, the findings may lead to the design of new capacity-building interventions, new research, and areas of advocacy for promoting adolescents' well-being.

Study findings will inform the interventions introduced for gender and sexuality education and for psychoeducational programs in BIED, BRACU's junior secondary schools serving adolescents ages 12-15. The program aspires to meet the cognitive, emotional, sexual, and psychological transformation of adolescents 
and it is anticipated that provisions for psychosocial support or need-based counseling services for adolescents will need to be in place.

To provide psychosocial support, BIED, BRACU introduced new para-counselors-local females aged 19-22called shomaj shongees (SS) (social companions) at pilot junior secondary schools (SSCOPE). The shomaj shongees are responsible for dedicated weekly classes on gender and sexuality education, mental health education, and creative arts that foster emotional well-being and allow adolescents both access to information and a forum to raise questions/concerns they might have on these topics. Additionally, the shomaj shongees provide opportunities for individual and group counseling to adolescents and sensitize parents toward the developmental needs of adolescent girls and boys through positive parenting sessions. It was learned from the implementation of the model that one shomaj shongee can successfully address the informational and psychosocial needs regarding sexual harassment and abuse and other areas of SRHR and emotional well-being of a group of 35-40 students at a school.

Through its development at SSCOPE schools over the last year, the education, support, and socialization related to comprehensive gender and sexuality education and emotional well-being introduced by shomaj shongees has proven widely effective in: a) offering opportunities for young adolescents to access knowledge and information on a range of themes including body image and self-image, relationships, sexual abuse, puberty, and reproductive health, including early marriage and early pregnancies, unsafe abortion, HIV/AIDS and STDs/RTIs; goal setting; time, stress, and anxiety management; and b) building cognition and creativity and the ability of adolescents to find relief from stress and anxiety, to concentrate on studies, to exercise control over external circumstances, to express concerns openly, to be heard, and to become active agents in shaping their destiny.

The intervention was also successful in: developing help-seeking behaviors; reducing school dropout rates which, in turn, increase future life opportunities; fostering the freedom to live a life that one values and to manage one's affairs adequately; fostering autonomy and capacity to make free and informed decisions about their well-being; reinforcing choices, expanding human agency; and promoting social competence and opportunities in their lives. The model advocates in favor of allocating resources that integrate the three core components: education; gender and sexuality education; and emotional well-being in ways that recognize and address adolescents' rights in both the urban and rural settings of Bangladesh and elsewhere.

\section{Dr. Erum Mariam Director BIED, BRACU}




\section{List of Abbreviations}

$\begin{array}{ll}\text { ADP } & \text { Adolescent Development Program } \\ \text { AIDS } & \text { Acquired Immune Deficiency Syndrome } \\ \text { BALIKA } & \text { Bangladeshi Association for Life skills, Income, and Knowledge for Adolescents } \\ \text { BBS } & \text { Bangladesh Bureau of Statistics } \\ \text { BDHS } & \text { Bangladesh Demographic and Health Survey } \\ \text { BDI } & \text { Beck Depression Inventory } \\ \text { BIED, BRACU } & \text { BRAC Institute of Educational Development, BRAC University } \\ \text { EPI } & \text { Expanded Program on Immunization } \\ \text { FRA } & \text { Field Research Assistant } \\ \text { HIV } & \text { Human Immunodeficiency Virus } \\ \text { MDG } & \text { Millennium Development Goal } \\ \text { MICS } & \text { Multiple Indicator Cluster Survey } \\ \text { MR } & \text { Menstrual Regulation } \\ \text { NIPORT } & \text { National Institute of Population Research and Training } \\ \text { PTSD } & \text { Post-Traumatic Stress Disorder } \\ \text { RTI } & \text { Reproductive Tract Infection } \\ \text { SRHRG } & \text { Sexual and Reproductive Health and Rights and Gender } \\ \text { SS } & \text { Shomaj Shongee } \\ \text { SSC } & \text { Secondary School Certificate } \\ \text { STD } & \text { Sexually Transmitted Disease } \\ \text { UNICEF } & \text { United Nations Children's Emergency Fund } \\ \text { WHO } & \text { World Health Organization } \\ & \end{array}$




\section{Executive Summary}

The Urban Adolescents Needs Assessment Survey was designed to provide general information on urban adolescents and specific recommendations for those designing programs and policies for adolescents living in urban areas. The survey was conducted in six thanas located in Dhaka North, Dhaka South, and Gazipur district near Dhaka city from April to May 2014. Participants included adolescent girls and boys ages 12-19 sampled from, and interviewed in, their homes. The total sample size is 3,585 successfully completed interviews and includes married and unmarried adolescents.

Background data on asset ownership and family characteristics collected from adolescents and household informants suggest that Dhaka North is the wealthiest district and Gazipur is the least wealthy in terms of asset ownership and occupational status. Overall, this urban population is more predominantly Muslim than the population of the country as a whole. Family size as measured by average number of siblings is 2.23 , with Gazipur having a slightly higher average family size of 2.43. Ninety-two percent of adolescents have living fathers and mothers. Almost all households have electricity. Eighty-seven percent own televisions and $96 \%$ own mobile phones. Relatively high proportions own their own homestead land (84\%) and a little under half own arable land as well. The parents of almost a third of all adolescents have no education, and these rates are similar for fathers and mothers. However, $28 \%$ of fathers have 10 years of education or more (Secondary School Certificate and above), while 17\% of mothers are reported in this category. The areas vary in terms of fathers' occupational distribution-33\% are professional in Dhaka North, compared with $20 \%$ in Dhaka South and 17 percent in Gazipur. More than 85\% of mothers are reported to be housewives.

The survey documents what many recent studies have found-that education levels are rising in urban Bangladesh, and as a result adolescents are more educated than their parents. The percentage of adolescents who have never been to school in this sample is less than $4 \%$. Some sex differences in school attainment and performance are observed. Girls who are in school have slightly higher levels of schooling than boys, but girls tend to drop out after puberty resulting in their attaining lower overall levels of schooling. Only about $5 \%$ of adolescents report receiving governmental stipend support. This is because programs to provide such support typically do not cover urban areas. The majority of adolescents (80\%) who are in school are tutored at home by private tutors, and more than half pay Tk1,000 (US\$13) per month or more. Assessments of learning suggest that the quality of schooling is poor, particularly for mathematics. Most adolescents are able to read well in Bangla, their native language. English language competency is better in urban than rural areas.

Assessments of learning competencies on a range of indicators suggest that sex differences and age-related differences are small. However, there are considerable differences by level of schooling completed and by whether adolescents are currently in or out of school, the latter suggesting that adolescents who are no longer in school may lose some of the competencies they attained while in school.

Early marriage among urban adolescent girls is high and comparable to early marriage rates in rural areas. Nearly $20 \%$ of girls ages $12-19$ are married, compared with $1 \%$ of boys. About one in four marriages is described as "own choice" and the remaining are arranged. The reason most often given for marriage is that a proposal is "too good to refuse." Marriage registration is common, with $94 \%$ of married adolescents reporting that their marriage was registered. However, reports of dowry payment were surprisingly low.

Responses to questions about sexual and reproductive health knowledge and practice suggest that knowledge levels are poor for unmarried adolescents and boys. Although HIV/AIDS is relatively uncommon in the country, sexually transmitted diseases (STDs) are not; knowledge about HIV/AIDS is much higher than knowledge about other forms of sexually transmitted diseases. Family planning knowledge and contraceptive use is high among married adolescents, with $62 \%$ of married adolescents reporting use of a method. The pill is the most commonly used method for girls and condom use is most common for boys. Girls are much more likely than boys to be sexually active at a young age because of early marriage. 
Boys and girls face restrictions on their mobility, and girls are more restricted than boys. Boys and girls express gender inequitable values on a range of indicators, but boys hold more inequitable values than girls. Women's seclusion in the form of purdah practice is condoned by both boys and girls. Although respondents generally express equitable values when it comes to general principles such as the right to equality or education, more gender inequitable values emerge when asked about role expectations, with adolescents overwhelmingly endorsing views that women should be primarily responsible for domestic chores and that violence against women is acceptable under certain conditions.

The survey includes an assessment of mental health using the the 21-point Beck Depression Inventory that highlights poor mental health as an important area of concern. The analysis finds elevated levels of risk of moderate to severe depression associated with orphanhood, past experience of violence, poor school performance, and traumatic experiences in childhood. More striking is the higher levels of depression associated with pregnancy and childbearing among girls relative to girls who have not yet experienced those lifecycle transitions. A question on what counseling topics would be of most interest suggests that professional help to reduce career- and education-related stress is an important area for unmarried adolescents, while SRHR and relationship concerns are important for married adolescents.

Overall, about a third of all adolescents work, but boys are more likely to work than girls. Urban adolescent girls are more likely to work than rural girls, and nearly one in four adolescent girls are engaged in incomeearning activities. Boys and girls work in different occupations. While the service sector is the dominant sector of employment for boys, garment factories are the dominant place of work for adolescent girls. Girls who are in school earn by tutoring children.

Girls work an average of 40 hours and boys work an average of 50 hours per week. Boys earn $50 \%$ more than girls. Although labor force participation is highest among the least educated, returns from education are high and even adolescents with incomplete primary education earn more per hour than adolescents with no education. However, adolescents with no education work long hours and their overall earnings are higher than adolescents with higher levels of education.

Adolescent girls tend to hold their assets in the form of gold and silver, even among the most educated girls, suggesting that adolescents either do not have access to alternative ways of saving or they prefer to save in the form of gold or silver, which is the traditional form of asset holding particularly for women.

In several aspects, the survey did not replicate results reported in other surveys. In particular, reported levels of experience of harassment and violence were much lower in this survey compared with past studies in urban and rural Bangladesh. Reports of sexual activity outside marriage and drug use were also low, as was the percentage of marriages reported to involve dowry. It may be possible that the survey underreported these behaviors, suggesting that it is important to offer higher levels of privacy and anonymity than what the current survey was able to provide.

There are some ways in which the survey did replicate results from other recently conducted studies. The results reported by the current study on measures of gender inequitable values and norms suggest that urban adolescents' values are similar to those of rural adolescents. The majority held that girls should begin practicing purdah at a young age. Boys are somewhat more likely than girls to hold such values. 


\title{
Chapter 1 Introduction
}

\author{
NASHIDA AHMED
}

This report presents data on multiple dimensions of adolescents' lives in urban settlements in Dhaka and Gazipur districts, Bangladesh. The study provides evidence on the lives of young people in urban Bangladesh in a manner that can inform programs and policies directed toward this underserved population. We present data on education, including school experience and competency assessments; reproductive health; family planning knowledge and practices; marriage and dowry; physical mobility and social context; gender equality; family life, relationships, and emotional well-being; substance abuse-drug and alcohol; and livelihoods. There is presently little information about what makes adolescent girls and boys vulnerable in urban settings. The analysis explores and highlights sex, age, education, and marital-status-related differentials among adolescents. We hope to offer an evidence base that will generate discussions about programs and policies at the national level in Bangladesh and inform policy and future programming about target-oriented and equity-focused positive youth-development approaches to improve the lives of adolescent girls and boys in low-resource settings.

In addition to assessing adolescent lives in terms of education, school, and work, the survey included questions about the perceptions, opinions, knowledge, attitudes regarding gender and rights, and career aspirations of adolescent girls and boys aged 12-19 in the urban areas of Dhaka and Gazipur. In addition to commonly used questions on sexual and reproductive health, educational access and schooling, and gender norms and behavior, two domains in the survey are relatively novel: the survey included extensive assessments of learning outcomes in terms of reading abilities and comprehension, and numeracy and analytical thinking. It also included a detailed assessment of mental health, which allows us to investigate correlations and associations across the various domains.

The study was developed by the Population Council in collaboration with the BRAC Institute of Educational Development, BRAC University (BIED, BRACU). The Population Council brings an extensive body of knowledge on adolescent programming worldwide, and BIED, BRACU is in the forefront of program innovation on education in Bangladesh.

\section{FOCUS ON ADOLESCENTS}

According to the 2011 census, adolescents constitute more than one-fifth of the population of Bangladeshwith 13.7 million girls and 14 million boys (National Plan of Action 2013). Adolescents today belong to the largest ever cohort to come of age. This large cohort is a legacy of periods of high population growth in the recent past. Adolescents have never in the past represented such a large segment of the population.

Adolescents (10-19 year olds) experience rapid social, physical, and emotional changes (Amin et al 2013; Dube and Sharma 2012). Adolescence is increasingly recognized as the critical phase in human development that sets the stage for later life. It is also a time to develop knowledge and skills, to learn to manage emotions and relationships, and to acquire attributes and abilities that are important for enjoying the adolescent years and assuming adult roles (WHO 2014). Appropriate support structures and skills can lead to increased independence and the development of positive and healthy behaviors during this period of transition. Without this support, however, adolescence can be a time of great risk (Amin et al. 2013).

Amin et al. (2013) further suggest that investing in adolescence is the most effective way to consolidate the historic global gains that have been achieved in early and middle childhood since 1990. The near 
elimination of the gender gap in primary-school enrollment in several developing regions and the considerable gains in improving access to primary schooling are testament to the tremendous progress achieved for children in early and middle childhood. But the limited attention, resources, and support devoted to adolescents' rights and well-being is threatening to limit the impact of these efforts in the second decade of an individual's life.

While all adolescents confront distinct vulnerabilities during this phase of transition, young adolescents (1014 years), particularly girls, face increased risks for a number of reasons. Girls enter puberty on average two years earlier than boys. Possibly as a result of this earlier maturity, in many settings girls are more likely than boys to drop out of school and marry at an early age, which often leads to poor sexual and reproductive health outcomes. Leaving school can increase vulnerability among girls, who often do not return. As a result, girls are left socially isolated without sufficient knowledge and skills to effectively navigate life's challenges (Amin et al. 2013).

\section{FOCUS ON URBAN POPULATIONS}

A second factor distinguishing contemporary populations is the unprecedented and rapid pace of urbanization. The fast pace of urbanization in Asia and Africa reflects a rapidly changing world. An estimate provided by the State of the World's Children 2012 (UNICEF 2012) illustrates that every year the world's urban population increases by about 60 million. Most of this growth is taking place in low- and middleincome countries. It is estimated that by 2050,7 in 10 people will live in cities and towns. Asia is home to half of the world's urban population.

While urban settings may offer a greater range of services than rural areas, children from poorer families or marginalized communities do not always enjoy equal access to these services. All over the world many urban inhabitants live close to schools or hospitals but have little chance of using these services due to discrimination, poverty, direct and indirect costs, poor transportation, etc. This is particularly true in the case of urban populations living in slum conditions. It is estimated that by 2020 some 1.4 billion people will live in informal settlements and slums in which exclusion due to poverty is often reinforced by discrimination on the grounds of gender and other social determinants, such as disability. To address these challenges globally, Target 11 of Millennium Development Goal (MDG) 7 aims to achieve a significant improvement in the lives of at least 100 million slum dwellers by 2020.

Bangladesh is experiencing one of the most rapid urbanization processes in Asia. The urban population in Bangladesh increased from 5 percent in 1971 (UNICEF 2010) to 28 percent in 2012 (UNICEF 2012), resulting in approximately 41.7 million people currently living in urban areas. Nevertheless, Bangladesh remains a mostly agrarian country. It is estimated that the urban population will reach 50 million in 2015, representing just under one-third (30 percent) of the total population. The slum population was about 5 percent of the total population in 2010, or about 7 million people (UNICEF 2010).

Rapid urbanization in Bangladesh is attributed to migration from rural to urban areas in search of economic opportunities, even though services remain poor in urban areas (and almost nonexistent in slums). Data from UNICEF's 2009 Multiple Indicator Cluster Survey (MICS) in Bangladesh make it clear that conditions in slum areas are much worse than those in most rural areas, in terms of service-delivery-related indicators such as access to health care and education. While the national average for attendance in secondary education is 49 percent (48 percent in rural areas and 53 percent in urban areas), the average is only 18 percent in urban slums. Net attendance in secondary education is $14 \%$ in Dhaka's slums (UNICEF 2010). Similarly, the slum areas recorded the highest dropout rate for secondary schools, especially for girls, where more than 16 percent of girls dropped out of school. For boys, the dropout rate is 10 percent (BBS and UNICEF 2010).

The poor quality of and access to education is reflected in literacy rates. BDHS 2011 data suggest that urban literacy rates are lower than rural literacy rates: in urban areas among ever-married women ages 15$19,8.8 \%$ can read a whole sentence, $8.4 \%$ can read part of a whole sentence, and $27.6 \%$ cannot read at all. The literacy rate is slightly higher in rural areas where among ever-married women aged 15-19: $10.8 \%$ can read a whole sentence, $11.1 \%$ can read part of a whole sentence, and $40.3 \%$ cannot read at all (NIPORT, Mitra and Associates, and ICF International 2013). 
The high prevalence of child marriage is associated with, and may explain the relatively high level of, dropout of girls relative to boys. The Bangladesh Urban Health Survey (NIPORT et al. 2008 in Amin, Rahman, and, Hossain 2012) shows that female's marriage takes place earlier in slum populations than in nonslum populations and in rural areas. Based on data from 2,989 ever-married women in urban slums, Amin, Rahman, and Hossain (2012) concluded that more than one-third of the women married before the age of 15. Rashid (2011) finds that among many motivating factors, poverty and dowry (the illegal but widely accepted and practiced payment of cash or goods to the groom) were very important factors for many of the families who married off daughters early to avoid paying large amounts of money (Rashid 2011).

\section{ADOLESCENT MENTAL HEALTH}

Mental health is an important area of focus for the present study. It is estimated that around $20 \%$ of the world's adolescents have mental health or behavioral problems. Depression is the single largest contributor to the global burden of disease for people aged 15-19, and suicide is one of the three leading causes of mortality among individuals aged 15-35 (UNICEF 2011). Many adolescents who participated in the WHO global consultation on adolescent health consider mental health the most important health problem faced by adolescents today and they would like more access to mental health care (WHO 2014). Mental health problems among adolescents may carry high social and economic costs if they interfere with acquiring educational and life skills. Stigma associated with mental disorders amplifies the adverse consequences. Mental health problems among young people present a major public health challenge worldwide. Preventive efforts can help forestall the development and progression of mental disorders, and early intervention can limit their severity.

Greater public awareness of mental health issues and general social support for adolescents are essential to effective prevention and assistance. Safeguarding adolescent mental health begins with parents, families, schools, and communities. Educating these critical stakeholders can help adolescents enhance their social skills, improve their problem-solving capacity, and gain self-confidence, which may in turn alleviate mental health problems and discourage risky and violent behaviors.

Early recognition of emotional distress and the provision of psychosocial support by trained individuals-who need not be health workers-can mitigate the effects of mental health problems. Psycho-educational programs in schools, supportive counseling, and cognitive behavioral therapy-ideally with the involvement of the family-are all effective in improving the mental health of adolescents, while the complex needs of young people can also be addressed through referrals to specialist services (UNICEF 2011).

In Bangladesh, the National Education Policy (2010) has committed to introducing effective studentcounseling programs in schools, realizing that students often become confused and misled because of the multiple problems they face. The policy further states that student welfare and counseling will be initiated and strengthened at all educational levels and that teachers delivering counseling will be properly trained. Importance will be attached to the establishment of a national student welfare counsel and advisory center to guide teacher-counselors and facilitate training programs so that better help can be provided for the students. 


\title{
Chapter 2 \\ Research Design and Methodology
}

\author{
MD. ABUL KALAM AND SIGMA AINUL
}

This study is part of a broader needs assessment exercise that identifies important areas of intervention for urban adolescents in Bangladesh. The assessment focuses on adolescents aged 12-19 living in or near Dhaka's metropolitan area. The goal of the study is to describe adolescent lives in the domains of education, work, social life, and interpersonal relationships. The study assesses the learning/educational, psychological, social, emotional, skill development, vulnerabilities, and reproductive and sexual health needs, experiences, views, attitudes, and desires of adolescent girls and boys in Bangladesh. The objective is to identify key areas of support required by adolescents from diverse educational, economic, ethnic, and gender backgrounds as well as those with special needs.

It is expected that this needs assessment will generate insights for developing skills and creating opportunities for "positive youth development" through academic and nonacademic programs/interventions that improve learning across the lifespan of adolescent girls and boys aged 12-19, and that retention in educational institutions including government and private secondary schools and madrasas, will be expanded.

\section{STUDY LOCATION AND POPULATION DESCRIPTION}

The Urban Adolescents Needs Assessment Survey was conducted in six thanas located in three city corporation areas of Dhaka North, Dhaka South, and Gazipur in Bangladesh. The thanas are Tongi, Gazipur in Gazipur district, Mirpur and Mohammadpur in Dhaka North and Jatrabari and Sutrapur in Dhaka South. Dhaka North and Dhaka South are the two administratively distinct parts of the metropolitan area, and Gazipur is a relatively new urban district located in the northern outskirts of the city. These are all locations of interest for BIED-BRACU because of a history of programs that have been implemented there.

\section{THE SURVEY}

A stratified cluster sample survey was undertaken for the study. The respondents for face-to-face interviews were randomly selected for the survey from a household roster. The study followed a four-stage sampling procedure to select areas and respondents in a stratified sample. At the first stage, in each stratum (Dhaka North, Dhaka South, and Gazipur) two thanas were selected that were average (neither too wealthy nor too poor) in terms of socioeconomic conditions. At the second stage, two wards from each thana were selected through simple random sampling. At the third stage, two mohallahs were randomly selected from each of the selected wards. At the fourth stage, household rosters were done in selected mohallahs to get a sufficient number of sample adolescents.

The report describes the data by enrollment status, age group, and marital status in addition to area as key variables of interest that were used to determine the sample size for the survey. Considering enrollment statistics available in the 2011 Population Census as the limiting criteria, the minimum required sample size was assessed to be 576 per strata (Population Census 2011). We arrived at such a figure adopting 95 percent confidence limit and 5 percent precision level, and multiplying the sample size by 1.5 to reduce the design/cluster effects (Cochran 1977; Kalton 1983). This figure was extended to 604 by adding 28 (5\% of 576 as nonresponse) for convenience of allocation and execution. The annex to this chapter (Annex 2.1) gives details of sample-size determination. 
Because different studies on education highlighted variations in educational attainment among the geographical regions in the country, three separate surveys were carried out, one in each of the three strata-Dhaka North, Dhaka South, and Gazipur city corporations.

In order to derive separate estimates for boys and girls, it was necessary to double the above sample size. This meant that 1,208 $(604 \times 2)$ young people aged $12-19$ years needed to be brought under the survey in each of the stratum indicated above, totaling 3,624 (1,208 $\times 3$ stratum), including 1,812 boys and 1,812 girls for the whole study. The final sample size after refusals and incomplete interviews was 3,585.

\section{THE SURVEY QUESTIONNAIRE}

Final data were collected from the adolescents sampled for the study. An instrument prepared for the survey with the sample adolescents by the research team based on the objectives of the study was reviewed and approved by the Population Council's Institutional Review Board. It was validated through field testing and the undertaking of a pilot study.

The piloting of the instrument was done in one area of Dhaka city. Thirty adolescents 12-19 years of age from that area were surveyed in the piloting of the instrument. The piloting helped in the reordering of the items in the instrument and identified areas needing special emphasis during the training of investigators for the final survey. It also helped in preparing code lists for responses to questions in different sections of the instrument. A final draft of the instrument was then prepared incorporating experiences gained through piloting. A brief description of the instrument is provided below.

The instrument/questionnaire has 14 substantive sections in addition to the identification section. These are: a) background characteristics, b) social capital and citizenship, c) time use and work, d) education, e) reproductive health, f) family planning knowledge and practices, g) marriage and dowry, h) mobility, i) solidarity and social context, j) gender equality, k) family life, relationships, and emotional well-being, I) substance abuse-drug, alcohol), m) livelihood, and n) aptitude test.

Identification of the household: This section of the instrument contains adolescent identification information including assigned numbers for the adolescent, his/her household, the mohallah, thana/cluster, and the stratum, i.e., the city corporation. It also includes the sex of the adolescent.

Background characteristics: This section includes adolescents' current age, national ID, religion, parental existence, siblings, parents' education and occupation, housing pattern, etc., and the household's other socioeconomic conditions in terms of access to electricity, ownership of land, furniture, and modern communication media items such as a radio, cell phone, and television.

Social capital and citizenship: This section of the instrument includes respondents' behavior toward electronic and print media, religious practice, physical exercise, participation in sports and cultural functions, and membership in different social, cultural, religious, youth, child, and development organizations. It also includes respondents' access to and use of a computer, cell phone, and Internet.

Time use and work: This section documents how much time respondents spend participating in various activities on an average day.

Education: Includes access to education, school enrollment status, progression, repetition, achievement in learning, aspiration with regard to education, school environment, school experience of the adolescent and pedagogy, participation in co-curricular and extracurricular activities, private tuition and its costs, participation in technical education and training, literacy achievement, etc.

Reproductive health: Specific types of information included in this section are: knowledge about the physical and mental changes that occur during puberty, concerns about puberty, and source of knowledge on puberty; knowledge and perception about and management of menses, reproductive-health-related problems and diseases and their management; and consequences of early pregnancy. This section also includes knowledge about STDs and HIV/AIDS and reasons why they spread. 
Family planning knowledge and practices: This section includes information on source of knowledge on sex, knowledge about and practices of family planning methods, and knowledge about and practices of menstrual regulation (MR).

Marriage and dowry: This section includes the marital status of adolescents, marriage registration, partner's education and occupation, reason for marriage, adolescents' role and consent in getting married, dowry, knowledge on punishment for demanding dowry, knowledge on legal age at marriage for boys and girls and girls' right to divorce, legal and personal consequences of early (before legal age) marriage, perceptions of polygamy, pregnancy- and child-related information, family planning methods and practices and partner's role in it, gender preference of child, prenatal care, and place of delivery.

Mobility: This section includes families' concerns about security, perceptions about purdah, mobility practices in different places, experiences of "eve teasing" (public sexual harassment) in different situations and places and their consequences, plus ways adopted to face these situations.

Solidarity and social context: Information in this section includes social context and environment the respondent lives in; depth of relation with spouse and others; perceptions of and practices toward friends of the opposite sex; disabled adolescents; friends from other religions, ethnicities, and communities; attitudes toward people and community from other religions and ethnicities.

Gender equality: This section includes attitudes toward and experiences of gender equality, inequality, and discrimination; role of males and females in the family on decision-making concerning different issues.

Family life, relationships, and emotional well-being: Specific information includes adolescents' level of social and emotional well-being following the Beck Depression Inventory (BDI); role of the adolescent in making decisions related to his/her education, career, etc.; knowledge and perceptions about, and demand for, help; helpline and counseling for the depressed and traumatized.

Substance abuse-drug and alcohol: This section focuses on adolescents' behavior related to substance abuse and its consequences.

Livelihood: This section includes information related to involvement in income-earning activities, type of activities, working hours per week, monthly income, and income from sources other than main occupation; role of the adolescent in decision on spending; ownership of land; livestock. computer, bicycle, and ornaments; participation in skill-development activities to enhance skills and capacity.

Aptitude test: This section includes a test that covers basic arithmetic and reasoning, and general knowledge.

\section{FIELDWORK, INVESTIGATORS AND THEIR TRAINING}

As mentioned earlier, data collection for the study was completed in two phases. In the first phase, a household roster was done to draw sample adolescents 12-19 years old from the household data. For the purpose, 25 field research assistants (FRAs), all university graduates, were recruited and trained to list 6,240 households from 25 February 2014 to 10 March 2014.

In the second phase, the main urban adolescents' needs assessment survey was conducted. Sixty-three people were recruited in late March 2014 for the implementation of the survey. All were university graduates and a significant number were experienced in doing similar work under different educational as well as other socioeconomic surveys. Fifty-four were finally selected for the fieldwork ( 22 males and 32 females) as they successfully completed the training workshops arranged for them and proved their competence in conducting the survey during the training workshops.

Training workshops were arranged for the recruited persons in two batches from 6-17 April 2014. Each training workshop continued for five days and included classroom discussions, role-play exercises, and practical exercises. A detailed instruction manual describing all sections of the instrument was also used in the workshops. Research team members of the BRAC Institute of Educational Development, BRAC University (BIED-BRACU) and the Population Council conducted the training sessions. 


\section{THE FIELD OPERATION}

The fieldwork was carried out from 19 April to 16 May 2014. Twelve teams consisting of four FRAs in each team conducted the fieldwork. A team of six supervisors monitored and supervised the fieldwork, each of whom was responsible for two teams.

Each team of two research assistants spent two days in a village/mohallah to survey the 27 households; in other words, eight days were spent in an upazila/municipality/thana to survey 108 households from four selected village/mohallahs in that area. The data-collection situation in Dhaka North and Dhaka South was different from that of Gazipur. The household survey in the Dhaka areas took more time, because access to households took longer negotiation and explanation due to security concerns. But in most cases, the interviewers convinced the respondents and completed the work successfully. The problem of access was more serious in sites under the stratum of Dhaka North and Dhaka South city corporation apartment complexes that have stronger security provisions.

Table 2.1: Sample size, completed interviews by location and sex

\begin{tabular}{|c|c|c|c|c|c|c|c|c|}
\hline $\begin{array}{l}\text { Stratum/city } \\
\text { corporation }\end{array}$ & $\begin{array}{l}\text { No. of } \\
\text { thanas }\end{array}$ & $\begin{array}{l}\text { No. of } \\
\text { Mohallahs }\end{array}$ & Sex & $\begin{array}{l}\text { No. of } \\
\text { samples } \\
\text { from } \\
\text { first } \\
\text { census }\end{array}$ & $\begin{array}{l}\text { Interviews } \\
\text { completed } \\
\text { from the } \\
\text { sample }\end{array}$ & Refusal & $\begin{array}{l}\text { Interviews } \\
\text { completed } \\
\text { from new } \\
\text { (additional) } \\
\text { census }\end{array}$ & $\begin{array}{l}\text { Total } \\
\text { interviews } \\
\text { completed }\end{array}$ \\
\hline \multirow[t]{3}{*}{ Dhaka North } & \multirow[t]{3}{*}{2} & \multirow[t]{3}{*}{8} & Boys & 647 & 598 & 42 & - & 598 \\
\hline & & & Girls & 756 & 600 & 72 & - & 600 \\
\hline & & & Both & 1,403 & 1,198 & 114 & - & 1,198 \\
\hline \multirow[t]{3}{*}{ Dhaka South } & \multirow[t]{3}{*}{2} & \multirow[t]{3}{*}{8} & Boys & 542 & 490 & 52 & 96 & 586 \\
\hline & & & Girls & 550 & 488 & 62 & 115 & 603 \\
\hline & & & Both & 1092 & 978 & 114 & 211 & 1,189 \\
\hline \multirow[t]{3}{*}{ Gazipur } & \multirow[t]{3}{*}{2} & \multirow[t]{3}{*}{8} & Boys & 625 & 565 & 27 & 33 & 598 \\
\hline & & & Girls & 663 & 562 & 53 & 38 & 600 \\
\hline & & & Both & 1,288 & 1,127 & 80 & 71 & 1,198 \\
\hline \multirow[t]{3}{*}{ Total } & \multirow[t]{3}{*}{6} & \multirow[t]{3}{*}{24} & Boys & 1,814 & 1,653 & 121 & 129 & 1,782 \\
\hline & & & Girls & 1,969 & 1,650 & 187 & 153 & 1,803 \\
\hline & & & Both & 3,783 & 3,303 & 308 & 282 & 3,585 \\
\hline
\end{tabular}

The heads of the households were the principal respondents for the household roster for the most part, and the interviews with the adolescents were held at the premises of the households. The criterion of principal decision-maker in the household was maintained in deciding the heads of the households in the household roster. If s/he was not available, the spouse was chosen for the purpose. If neither was available, any adult member of the household was asked to provide information. As in similar studies, age determination was the hardest job in the household survey because of the absence of a credible birth-registration system and the inability of parents to remember birth dates or ages of their children. Events calendar and Expanded Program on Immunization (EPI) cards were used in attempting to ascertain age of household members. In interviewing the adolescents, FRAs maintained a congenial environment and ensured that only the FRA and the sample adolescents were there because there were questions in the instrument that respondents might feel shy about responding to in front of onlookers. The FRAs followed standard form by getting consent from both the respondents as well as their parents, using prescribed consent forms prior to interviewing the adolescents. On average, a research assistant surveyed three to four adolescents a day. After completing the 
interview with a selected adolescent, the FRAs carefully checked the filled-in questionnaire to ensure that all questions in the instrument were covered and that answers were recorded properly.

\section{DATA QUALITY ASSURANCE}

Several measures were taken to maintain the quality of data. A detailed supervision and quality-control protocol was devised to ensure data quality. As mentioned earlier, each supervisor was responsible for supervising the work of two teams and for ensuring the quality of the data. The supervisor's tasks included seeing whether the teams went to the right places and persons (mohollahs/households/respondents) and the FRAs worked as instructed. They rechecked the filled-out questionnaires and also re-interviewed samples of the surveyed adolescents on some selected indicators, and ensured the correction by the FRAs in the field in case of any discrepancy. Apart from this, a monitor oversaw overall field-data collection activities through random visits to field sites. Frequent contact was maintained between research managers and the field teams by telephone from BIED-BRACU.

In verifying the quality of data, the findings of Education Watch studies were compared for plausibility of variations in findings. Findings of the Household Income and Expenditure Survey 2010, Census 2011, and the baseline survey of the Population Council's BALIKA 2013 project (Bangladeshi Association for Life skills, Income, and Knowledge for Adolescents) were also consulted. It was observed that the distributions in key indicators (proportion of age group, school enrollment, marital status, etc.) found in the present study were consistent with those found in the above studies.

More than $4 \%$ of the adolescents (150 in number) were brought under re-enumeration. Instead of the whole questionnaire, a number of key variables were chosen from this to match with the original data to find deviations. The matching operation shows that the data quality was satisfactory. The matching rate was more than $95 \%$ in most cases (Table 2.2).

\section{Table 2.2: Percentage of matched cases (main survey and re-interview), selected indicators}

\begin{tabular}{|l|l|}
\hline Indicators & $\%$ matched \\
\hline Sex of the adolescents & 98.0 \\
\hline Current age of the adolescents & 96.7 \\
\hline School enrollment of the adolescents & 98.0 \\
\hline Marital status of the adolescents & 98.0 \\
\hline
\end{tabular}

\section{BACKGROUND CHARACTERISTICS OF THE ADOLESCENTS}

Table 2.3 presents selected background characteristics of the 12-19-year-old adolescents studied. About 11 percent of the adolescents have ever been married and this proportion varied according to areas. Girls are considerably more likely to be married than boys, with $19.9 \%$ of girls ever married, compared with less than $1 \%$ of boys (not shown). Most (almost 95.7\%) of the adolescents were Muslim, while 4.2 percent were Hindu, and these proportions varied by area with the highest proportion non-Muslim in Dhaka South (8.2\%). Around three-fourths of the respondents have a birth registration card and this proportion was found to be the lowest (68.5\%) in Dhaka South. On average, the respondents have 2.23 siblings, with the highest (2.43) in the Gazipur city corporation area. Age distribution of adolescents indicated that slightly more than half were from the 12-15-year age group, and this proportion was the highest $(57.7 \%)$ among the adolescents in Dhaka South and the lowest (47.7\%) in Dhaka North. More than nine-tenths of the respondents have two living parents, while less than $1 \%$ have no living parents and $6.5 \%$ have lost their fathers. Almost all of the respondents' households have electricity and phone/mobile phone; slightly less than nine-tenths have a television, with the lowest (80.4\%) in Gazipur city corporation area. More than four-fifths of the households have their own homestead, with the highest (90.2\%) in Gazipur, and less than half have arable land with the highest (55.1\%) also in Gazipur (Table 2.3). A comparison of asset ownership data from this survey to the 
subsample of the Demographic and Health Survey that covered Dhaka city corporation gives us confidence that the sample households in the two surveys have similar socio-economic characteristics (author's calculation from the DHS 2011 survey).

Table 2.3: Adolescents by selected background characteristics and area of residence

\begin{tabular}{|c|c|c|c|c|}
\hline \multirow[t]{2}{*}{ Background characteristics } & \multicolumn{3}{|c|}{ City corporation/area (\%) } & \multirow{2}{*}{$\begin{array}{l}\text { All areas (\%) } \\
N=3,585\end{array}$} \\
\hline & $\begin{array}{l}\text { Dhaka North } \\
N=1,198\end{array}$ & $\begin{array}{l}\text { Dhaka } \\
\text { South } \\
N=1,190\end{array}$ & $\begin{array}{l}\text { Gazipur } \\
N=1,197\end{array}$ & \\
\hline \multicolumn{5}{|l|}{ Marital status } \\
\hline Ever married & 10.3 & 6.8 & 16.2 & 11.1 \\
\hline Never married & 89.7 & 93.2 & 83.8 & 88.9 \\
\hline \multicolumn{5}{|l|}{ Religion } \\
\hline Islam & 98.2 & 91.8 & 97.1 & 95.7 \\
\hline Hindu & 1.6 & 8.2 & 2.9 & 4.2 \\
\hline Christian & 0.2 & 0.0 & 0.0 & 0.1 \\
\hline Have birth registration card & 76.0 & 68.5 & 78.0 & 74.2 \\
\hline \multicolumn{5}{|l|}{ Age group } \\
\hline $12-15$ years & 47.7 & 57.7 & 52.0 & 52.5 \\
\hline $16-19$ years & 52.3 & 42.3 & 48.0 & 47.5 \\
\hline Mean number of siblings & 2.14 & 2.13 & 2.43 & 2.23 \\
\hline \multicolumn{5}{|l|}{ Parental existence status } \\
\hline Both parents alive & 92.6 & 90.5 & 91.4 & 91.5 \\
\hline Only father alive & 1.2 & 0.8 & 1.3 & 1.1 \\
\hline Only mother alive & 5.2 & 7.8 & 6.4 & 6.5 \\
\hline No parents alive & 1.0 & 0.8 & 0.8 & 0.9 \\
\hline \multicolumn{5}{|l|}{ Household assets } \\
\hline Electricity & 99.5 & 99.7 & 96.8 & 98.7 \\
\hline Television & 90.3 & 90.5 & 80.4 & 87.1 \\
\hline Phone/mobile phone & 96.3 & 96.6 & 96.0 & 96.3 \\
\hline Computer & 32.0 & 16.0 & 8.0 & 18.7 \\
\hline Homestead land & 84.1 & 77.0 & 90.2 & 83.8 \\
\hline Arable land & 48.2 & 33.2 & 55.1 & 45.5 \\
\hline
\end{tabular}

About two-thirds of the parents of adolescents have some education of different levels; the remaining onethird have no education. Fathers were found to be more educated than mothers; $28 \%$ of the fathers have a Secondary School Certificate (SSC) degree and above, while this proportion for the mothers was $17 \%$. Parents' level of education varied, with Dhaka North having the highest levels of education and Gazipur having the lowest (Table 2.4). Occupational distributions showed that Dhaka North had the highest proportion in the highest status of professional categories (33\%) followed by about $32 \%$ reporting being in 
business. In Dhaka South, 45\% of fathers were reported to be in business. In Gazipur, 30\% were in business. Gazipur had the highest proportion of fathers in the unskilled labor category (13\%) (Table 2.5). The overwhelming majority of mothers (85\%) were reported to be housewives. About $6 \%$ of mothers were reported to be professionals in Dhaka North and another $6 \%$ were described as unskilled labor in that area; $9 \%$ of mothers were described as garment workers in Gazipur, contrasted with less than $1 \%$ in Dhaka South and $2 \%$ in Dhaka North.

Table 2.4: Adolescents by parental education and area of residence

\begin{tabular}{|c|c|c|c|c|}
\hline \multirow[t]{2}{*}{ Background characteristics } & \multicolumn{3}{|c|}{ City corporation/area (\%) } & \multirow{2}{*}{$\begin{array}{l}\text { All areas } \\
(\%) \\
N=3,585\end{array}$} \\
\hline & $\begin{array}{l}\text { Dhaka North } \\
N=1,198\end{array}$ & $\begin{array}{l}\text { Dhaka } \\
\text { South } \\
N=1,190\end{array}$ & $\begin{array}{l}\text { Gazipur } \\
N=1,197\end{array}$ & \\
\hline \multicolumn{5}{|l|}{ Father's education } \\
\hline No education & 21.9 & 28.1 & 37.9 & 29.3 \\
\hline Primary level & 15.4 & 24.5 & 25.2 & 21.7 \\
\hline Secondary incomplete & 16.4 & 18.8 & 17.3 & 17.5 \\
\hline SSC and above & 43.7 & 24.6 & 15.5 & 28.0 \\
\hline Don't know & 2.6 & 3.9 & 4.0 & 3.5 \\
\hline \multicolumn{5}{|l|}{ Mother's education } \\
\hline No education & 24.1 & 27.6 & 42.7 & 31.5 \\
\hline Primary level & 23.2 & 27.0 & 28.1 & 26.1 \\
\hline Secondary incomplete & 21.9 & 27.9 & 19.9 & 23.2 \\
\hline SSC and above & 29.1 & 15.5 & 6.3 & 17.0 \\
\hline Don't know & 1.7 & 1.9 & 3.0 & 2.2 \\
\hline
\end{tabular}

Table 2.5: Distribution of parental occupation of adolescents by area of residence

\begin{tabular}{|l|l|l|l|l|}
\hline \multirow{2}{*}{ Background characteristics } & \multicolumn{3}{l|}{ City corporation/area (\%) } & $\begin{array}{l}\text { All areas } \\
\text { (\%) }\end{array}$ \\
\cline { 2 - 5 } & $\begin{array}{l}\text { Dhaka North } \\
\mathbf{N}=1,198\end{array}$ & $\begin{array}{l}\text { Dhaka } \\
\text { South } \\
\text { N=1,190 }\end{array}$ & $\begin{array}{l}\text { Gazipur } \\
\text { N=1,197 }\end{array}$ & $\begin{array}{l}\text { N=3,585 } \\
\text { Father's occupation }\end{array}$ \\
\hline Professional/Technical/Service & 33.2 & 19.6 & 17.4 & 23.4 \\
\hline Business & 31.9 & 45.2 & 28.9 & 35.3 \\
\hline Skilled labor & 13.3 & 18.0 & 17.8 & 16.4 \\
\hline Garment/Factory worker & 0.3 & 0.8 & 3.7 & 1.6 \\
\hline Unskilled workers/Worked abroad & 10.9 & 6.2 & 21.8 & 12.9 \\
\hline Unemployed & 7.5 & 3.7 & 4.2 & 5.1 \\
\hline Others & 3.0 & 6.6 & 6.2 & 5.3 \\
\hline Mother's occupation & & & & \\
\hline Housewife & 83.6 & 89.4 & 82.6 & 85.2 \\
\hline Professional/Technical/Service & 6.1 & 2.5 & 4.1 & 4.2 \\
\hline Business & 0.6 & 0.9 & 0.6 & 0.7 \\
\hline Skilled labor & 1.1 & 0.8 & 0.3 & 0.7 \\
\hline Garment/Factory worker & 2.0 & 0.8 & 9.2 & 4.0 \\
\hline Unskilled workers & 5.9 & 3.8 & 1.6 & 3.8 \\
\hline Unemployed/others & 0.8 & 1.9 & 1.6 & 1.4 \\
\hline
\end{tabular}




\section{LIMITATIONS OF THE STUDY}

This survey was done in three purposively selected areas of the city corporations of Bangladesh that have been locations of programs undertaken by BIED, BRACU. This might limit the generalization of the findings across the urban locations in the country. The interviews were conducted in face-to-face settings. As such, there are some limitations. Adolescents are unlikely to report on sensitive issues such as sexual initiation and may be hesitant to talk about sexual and reproductive health issues. As such, these variables should be interpreted with caution. In particular, the overall levels of practices are likely to be under-reported and some behaviors may be more sensitive for girls to report than boys. As in the case of other studies, analysis of the participation of targeted groups in this study in education and training assumes correct reporting of those aged 12-19 years. As mentioned earlier, estimation of age was difficult in the household survey, though the standard devices and techniques were applied to overcome this limitation. Two components of the survey, learning and mental-health assessment, are relatively new to Bangladesh. While both components have been assessed in other settings, there may be ways to further develop these instruments to make them more appropriate for the context of Bangladesh. 


\section{ANNEX 2.1: DETERMINATION OF SAMPLE SIZE}

Past and current enrollment status of the targeted young population was the key variable in determining sample size for the household survey. The variable enrollment in the skill-development activities was considered as dichotomously categorized as past and currently enrolled or not. The following formula was used in determining sample size (Cochran 1977; Kalton 1983).

$$
n=\frac{z^{2}(p \times q)}{a^{2}}
$$

Where,

$\mathrm{n}$ is the estimated sample size

$p$ is the probability of young people of targeted age past and /or currently enrolled in education

$q$ (1- $p)$ is the probability that young people of targeted age did not participate in education

$z \quad$ is the area of the standard normal curve under certain confidence limits

a is the desired level of precision, and

d is the design/cluster effect

Taking a value of 0.5 for both $p$ and $q$ (because such a value maximizes the sample size) and considering the confidence limit as $95 \%$ (of which the value of $z$ is 1.96) with $5 \%$ error level, it was calculated that the required sample size for an estimate stands at 384. This estimate was true if a random sampling procedure is applied. However, a stratified cluster sampling approach was followed in this study. Thus, to reduce cluster effect it was decided to multiply the size by 1.5 , which means the sample size stands at 576 , which was again extended to 604 for convenience of allocation and execution by adding $5 \%$ of the sample size as nonresponses.

The study intended 6 separate estimates ( 3 strata $\times 2$ sex), and thus the total sample required for an estimation of young people of the targeted age group's participation in education was $604 \times 6=3,624$, which required surveying some 6,240 households to get the required number of sample young people based on the information from HIES 2010 and Census 2011 produced by the Bangladesh Bureau of Statistics (BBS). 


\title{
Chapter 3 \\ Education and Learning Outcomes
}

\author{
MD. ABUL KALAM
}

This chapter examines aspects of urban adolescents' participation in education, school quality in terms of basic amenities, stipends, students' school and classroom experiences, private tuition and educational achievement in literacy, language, and mathematics, logical reasoning, and citizenry.

Education is important for eliminating gender inequality and reducing intergenerational transmission of poverty. Secondary education offers greater prospects of remunerative employment, with girls receiving substantially higher returns in the workplace than boys when both complete secondary school (Lloyd and Young 2009). Schooling also has implications for social well-being. In measuring the adolescent girls' vulnerability index, Amin et al. (2013) illustrate that girls' attendance in formal schooling is associated with: delayed sexual initiation, marriage, and child bearing; lower rates of HIV/AIDS; and engaging in fewer hours of domestic work. Globally, girls still lag behind boys in secondary-school participation, with net enrollment at 53\% for boys and 48\% for girls for the period 2005-09. Girls' disadvantage is highest in the least developed countries, particularly in sub-Saharan Africa and South Asia.

School attendance among adolescents has improved dramatically in rural Bangladesh. The net attendance rate in secondary education increased from 38.8\% in 2006 to 49.0\% in 2009 (BBS and UNICEF 2010). According to BDHS (NIPORT, Mitra and Associates, and ICF International 2013), secondary-level school enrollment of adolescents is $38 \%$. The dropout rate in secondary schools is much higher than in primary schools: about 48\% among girls and 38\% among boys (National Plan of Action 2013). Indeed, despite the school-based and household-incentive programs, Bangladesh's progress in improving secondary school completion rates has been far from satisfactory. Evidence remains of considerable gender disparity beyond the first 10 years of schooling, with girls dropping out at a faster rate than boys. Only $10 \%$ of girls who completed primary school passed the secondary school certificate (SSC) examination, compared with $25 \%$ of boys. Amin and Huq (2008) find that marriage and dowry considerations prevail in decisions about when to end a girls' schooling. Although girls continue attending school until they marry, very few are able to continue after marriage (Mahmud and Amin 2006). In another study on rural adolescents, Amin, Mahmud, and Huq (2002) reveal that early marriage remains a significant impediment to reaching the goals of education.

On reasons for nonparticipation of both girls and boys, Ahmed et al. (2007) highlight two issues: "scarcity of money" or poverty, and children's "dislike of school" indicating problems respecting classroom practices. The third most frequent response was the need for the child to work, which is linked to poverty. Poverty appears to be the paramount cause of nonparticipation in secondary education (Ahmed et al. 2007). Parents or family members are in control of the youth's education in terms of the decision when to drop out (Ali et al 2006). 


\section{PARTICIPATION IN EDUCATION/SCHOOLING OF ADOLESCENTS}

\section{Access and participation}

Distribution of adolescents studied by school enrollment status, sex, age group, and marital status are presented in Table 3.1. Data regarding current and past educational engagement of adolescents under the study show that two-thirds of young people aged 12-19 years are continuing education in some type of schooling. The rest in this age group are not continuing their education. They have completed different levels of education, have dropped out of the system, or have never enrolled in any educational program. An encouraging finding is that the proportion of never enrolled is relatively small at $3.2 \%$. The rate of continuation in education among the males (69.6\%) is higher compared with that of the females (62.7\%). This is consistent with the findings of the Education Watch 2011-12 study (Ahmed et al. 2013). The continuation rate is much higher (83.3\%) among the lower age group of $12-15$-year-olds and $73.0 \%$ among the never married adolescents, compared with $50.5 \%$ for the higher age group of $16-19$ years and only 11.5\% for the ever-married adolescents respectively (Table 3.1)

Table 3.1: Percentage of adolescents by participation in education, by sex, age group, and marital status

\begin{tabular}{|c|c|c|c|c|c|c|c|}
\hline \multirow[t]{2}{*}{ Enrollment status } & \multicolumn{2}{|c|}{ Sex (\%) } & \multicolumn{2}{|c|}{ Age group (\%) } & \multicolumn{2}{|c|}{ Marital status (\%) } & \multirow{2}{*}{$\begin{array}{c}\text { All (\%) } \\
N=3,585\end{array}$} \\
\hline & $\begin{array}{c}\text { Boys } \\
N= \\
1,782\end{array}$ & $\begin{array}{l}\text { Girls } \\
\begin{array}{l}N= \\
1,803\end{array}\end{array}$ & $\begin{array}{c}12-15 \\
\text { years } \\
N= \\
1,881\end{array}$ & $\begin{array}{c}16-19 \\
\text { years } \\
N= \\
1,704\end{array}$ & $\begin{array}{c}\text { Ever } \\
\text { married } \\
\mathrm{N}=398\end{array}$ & $\begin{array}{c}\text { Never } \\
\text { married } \\
N= \\
3,187\end{array}$ & \\
\hline Never enrolled & 3.3 & 3.2 & 2.6 & 3.9 & 5.3 & 2.9 & 3.2 \\
\hline $\begin{array}{l}\text { Ever enrolled but } \\
\text { currently not in school }\end{array}$ & 27.1 & 34.1 & 17.1 & 45.6 & 83.2 & 24.1 & 30.6 \\
\hline Currently in school & 69.6 & 62.7 & 80.3 & 50.5 & 11.5 & 73.0 & 66.2 \\
\hline
\end{tabular}

Source: Urban Adolescents Needs Assessment Survey in Bangladesh, 2014.

There are differences in currently enrolled, out of school, and nonenrollment figures for Dhaka North, Dhaka South, and Gazipur city corporations. For example, Dhaka North is performing better compared with the other two areas, and Dhaka South is doing better compared with Gazipur in terms of continuation of adolescents in education (Table 3.2). Around two-thirds of the adolescents are currently enrolled in school. 
Table 3.2: Percentage of adolescents by their access and participation in education and area of residence

\begin{tabular}{|l|c|c|c|c|}
\hline \multirow{2}{*}{ Enrollment status } & \multicolumn{2}{|c|}{ City corporation/area (\%) } & All areas (\%) \\
\cline { 2 - 5 } & $\begin{array}{c}\text { Dhaka } \\
\text { North } \\
\mathrm{N}=1,198\end{array}$ & $\begin{array}{c}\text { Dhaka } \\
\text { South } \\
\mathrm{N}=1,190\end{array}$ & $\begin{array}{c}\text { Gazipur } \\
\mathrm{N}=1,197\end{array}$ & N=3,585 \\
\hline Never enrolled & 3.8 & 2.8 & 3.1 & 3.2 \\
\hline Ever enrolled but currently not in school & 23.7 & 31.1 & 37.0 & 30.6 \\
\hline Currently in school & 72.5 & 66.1 & 59.9 & 66.2 \\
\hline N & 1,198 & 1,190 & 1,197 & 3,585 \\
\hline Repetition in any grade in secondary school & 7.1 & 16.8 & 15.2 & 12.8 \\
\hline N & 868 & 787 & 717 & 2,372 \\
\hline Reason for repetition among those who & & & & \\
repeated a grade & & & & \\
\hline Failed in the exam & 39.3 & 46.6 & 45.0 & 44.6 \\
\hline Migration & 9.8 & 14.3 & 13.8 & 13.2 \\
\hline Student's illness & 31.1 & 21.1 & 22.9 & 23.8 \\
\hline Family illness & 1.6 & 6.0 & 5.5 & 5.0 \\
\hline Other & 18.0 & 12.0 & 12.8 & 13.5 \\
\hline N & 62 & 133 & 109 & 304 \\
\hline Attended school on last school day & 91.9 & 85.3 & 84.1 & 87.3 \\
\hline N & 868 & 787 & 717 & 2,372 \\
\hline
\end{tabular}

Source: Urban Adolescents Needs Assessment Survey in Bangladesh, 2014.

\section{EDUCATIONAL ATTAINMENT OF IN- AND OUT-OF-SCHOOL ADOLESCENTS}

Table 3.3 presents the distribution of in- and out-of-school adolescents according to their educational attainment, sex, and age. Among adolescents who are enrolled in school, the distribution of level of schooling is similar, with girls being slightly more likely than boys to be in higher grades. However, as shown below, more boys than girls are enrolled. About $12 \%$ of boys and $9 \%$ of girls are studying in primary grades. Among the adolescents who discontinued education, the majority did so after the primary-school level and boys are more likely to have discontinued in early grades relative to girls-about $46 \%$ of them discontinued their education even before completing primary education compared with $27 \%$ of girls (Table 3.3). 
Table 3.3: Percentage of adolescents surveyed in and out-of-school by highest class passed, sex, and age group

\begin{tabular}{|c|c|c|c|c|}
\hline \multirow[t]{2}{*}{ Highest class passed } & \multicolumn{2}{|c|}{$\operatorname{Sex}(\%)$} & \multicolumn{2}{|c|}{ Age group (\%) } \\
\hline & Boys & Girls & $\begin{array}{c}12-15 \\
\text { years }\end{array}$ & $16-19$ years \\
\hline \multicolumn{5}{|l|}{ In-school adolescents } \\
\hline Primary incomplete & 11.9 & 8.7 & 15.6 & 1.2 \\
\hline Primary completed & 8.8 & 8.8 & 13.3 & 0.8 \\
\hline Secondary incomplete & 56.5 & 56.3 & 70.2 & 32.3 \\
\hline SSC and above & 22.8 & 26.3 & 0.9 & 65.7 \\
\hline $\mathrm{N}$ & 1,241 & 1,131 & 1,511 & 861 \\
\hline \multicolumn{5}{|c|}{ Out-of-school adolescents } \\
\hline Primary incomplete & 45.5 & 27.2 & 58.3 & 25.7 \\
\hline Primary completed & 19.5 & 16.1 & 18.7 & 17.1 \\
\hline Secondary incomplete & 32.1 & 42.3 & 22.7 & 44.0 \\
\hline SSC and above & 2.9 & 14.5 & 0.3 & 13.1 \\
\hline $\mathrm{N}$ & 483 & 615 & 321 & 777 \\
\hline
\end{tabular}

Most (83.5\%) of the adolescents aged $12-15$ years are studying in secondary grades followed by primary grades $(15.6 \%)$, while most (65.7\%) of the adolescents aged $16-19$ years are studying in higher secondary grades and above followed by secondary grades (32.3\%). Younger adolescents aged 12-15 years who discontinued with education discontinued while studying in primary grades. On the other hand, among adolescents aged $16-19$ years, $17.1 \%$ discontinued after completing primary education and $44.0 \%$ discontinued their education while studying in secondary grades (Table 3.3).

\section{Reasons for discontinuation}

Table 3.4 presents the distribution of the out-of-school adolescents by major reasons for their discontinuation with schooling and by sex. More than one-third of the adolescents who were no longer in school left due to lack of interest in education, one-fourth mentioned that their parents did not want them to continue in school, and $59.7 \%$ mentioned they had to care for siblings/others as major reasons for discontinuation. About half of the boys who were no longer in school mentioned their lack of interest in education as a reason for discontinuation; this proportion was 35.7\% for girls (Table 3.4). More girls than boys mentioned parents/guardian did not want them to continue with schooling and parents concern about their safety as reasons for discontinuation. The adolescents who mentioned marriage as a reason for their discontinuation in school were mostly girls. 
Table 3.4: Percentage of out-of-school adolescents by reason for discontinuation and sex

\begin{tabular}{|l|c|c|c|}
\hline \multirow{2}{*}{ Major reason for discontinuation } & \multicolumn{2}{|c|}{ Sex } & \multirow{2}{*}{ Both (\%) } \\
\cline { 2 - 4 } & Boys (\%) & Girls (\%) & 59.7 \\
\hline Had to care for siblings/others & 68.3 & 52.9 & 50.1 \\
\hline Student's lack of interest & 68.1 & 35.7 & 25.0 \\
\hline Parents/guardian did not want & 23.0 & 26.7 & 3.6 \\
\hline Parents concerned about safety & 1.2 & 5.4 & 25.4 \\
\hline Student's illness & 30.0 & 21.6 & 15.6 \\
\hline Had household work & 21.2 & 11.1 & 10.3 \\
\hline Financial constraints & 10.1 & 10.4 & 22.2 \\
\hline Got married & 0.01 & 38.6 & 1,098 \\
\hline N & 483 & 615 & \\
\hline
\end{tabular}

\section{Stipend}

Very few of the currently-in-school adolescents mentioned that they got a stipend in primary and secondary levels. Urban adolescents may not be eligible for means-tested government-sponsored stipend programs at the primary and secondary level. Comparable rates from a study in rural Bangladesh showed that over $50 \%$ received stipend support in primary school and 60\% received support in secondary school (Amin et al. 2014). In the current study, the highest percentage receiving a stipend in both the levels was in Gazipur, and the lowest at primary level in Dhaka South and at secondary level in Dhaka North (Table 3.5).

The proportion of adolescents who got a stipend was higher among girls than boys at both primary and secondary levels of education (Table 3.5). The higher age group of 16-19 year olds got more stipends than minor adolescents aged 12-15 years at both the primary and secondary levels (Table 3.5). The proportion of adolescents who reported receiving stipends was higher in Gazipur relative to Dhaka North and Dhaka South. 
Table 3.5: Percentage of currently enrolled adolescents surveyed by stipend receipt, sex, and age group

\begin{tabular}{|l|c|c|c|c|}
\hline \multirow{2}{*}{ Stipend } & \multicolumn{2}{|c|}{ Sex (\%) } & \multicolumn{2}{c|}{ Age group (\%) } \\
\cline { 2 - 5 } & Boys & Girls & $\begin{array}{c}12-15 \\
\text { years }\end{array}$ & $\begin{array}{c}16-19 \\
\text { years }\end{array}$ \\
\hline Stipend at primary level & & & & \\
\hline Yes & 5.6 & 7.8 & 6.0 & 7.7 \\
\hline No & 94.4 & 92.2 & 94.0 & 92.3 \\
\hline N & 1,241 & 1,131 & 1,511 & 861 \\
\hline Stipend at secondary level & & & & \\
\hline Yes & 3.0 & 7.9 & 3.0 & 9.3 \\
\hline No & 97.0 & 92.1 & 97.0 & 90.7 \\
\hline N & 1,241 & 1,131 & 1,511 & 861 \\
\hline Stipend & \multicolumn{2}{|c|}{ City corporation/area (\%) } & All areas (\%) \\
\cline { 2 - 5 } & Dhaka & Dhaka & Gazipur & \\
\hline Stipend at primary level & North & South & & \\
\hline Yes & & & & \\
\hline No & & & & \\
\hline N & 5.3 & 5.2 & 9.8 & 6.6 \\
\hline Stipend at secondary level & 94.7 & 94.8 & 90.2 & 93.4 \\
\hline Yes & 868 & 787 & 717 & 2,372 \\
\hline No & & & & \\
\hline N & 96.4 & 3.8 & 9.1 & 5.3 \\
\hline
\end{tabular}

\section{Private tutoring}

Distribution of currently enrolled adolescents by having private tutoring, subject, and monthly cost are presented by sex and age group in Table 3.6. A higher proportion of girls and younger adolescents aged 1215 years had private tutors relative to boys and older adolescents $16-19$ years, respectively. Boys were more likely to receive tutoring help in almost all subjects relative to girls except Bangla, Social Science and Geography. More of the younger adolescents were tutored in all the subjects compared with older adolescents. A slightly higher proportion of the boys paid more than Tk1000 monthly for tuition than the girls, and likewise a higher proportion of the older age group paid the same amount compared with the younger age group (Table 3.6). 
Table 3.6: Percentage of currently enrolled adolescents surveyed by private tutoring status, tutoring subjects, and monthly cost, by sex and age group

\begin{tabular}{|l|c|c|c|c|}
\hline \multirow{2}{*}{ Private tutoring status, subjects, and cost } & \multicolumn{2}{|c|}{ Sex (\%) } & \multicolumn{2}{c|}{ Age group (\%) } \\
\cline { 2 - 5 } & Boys & Girls & $\begin{array}{c}12-15 \\
\text { years }\end{array}$ & $16-19$ years \\
\hline N & 1,241 & 1,131 & 1,511 & 861 \\
\hline Have private tutor & 72.4 & 79.3 & 77.9 & 71.8 \\
\hline Subject of private tutoring* & & & & \\
\hline Bangla & 27.5 & 27.8 & 35.8 & 12.1 \\
\hline English & 87.3 & 83.1 & 87.2 & 81.1 \\
\hline Mathematics & 83.8 & 76.0 & 89.6 & 61.9 \\
\hline Science & 40.9 & 37.3 & 44.7 & 28.7 \\
\hline Geography & 2.8 & 3.5 & 3.8 & 1.9 \\
\hline Social Science & 12.4 & 13.7 & 17.9 & 3.9 \\
\hline N & 898 & 896 & 1,177 & 618 \\
\hline Monthly cost for private tutoring & & & & \\
\hline Tk500 or less & 6.2 & 7.0 & 8.3 & 3.5 \\
\hline Tk500-1,000 & 32.8 & 34.7 & 36.0 & 29.4 \\
\hline Tk1,000-2,000 & 33.1 & 33.9 & 33.4 & 33.7 \\
\hline More than Tk2,000 & 27.5 & 23.3 & 21.5 & 32.6 \\
\hline Don't know & 0.4 & 1.1 & 0.8 & 0.8 \\
\hline N & 898 & 896 & 1,177 & 618 \\
\hline
\end{tabular}

*Multiple responses.

Table 3.7 presents the distribution of the adolescents who reported being privately tutored, by their parent's level of education and by area. In all three areas, children of more educated parents were more likely to engage private tutors, suggesting that educated parents are either more strongly motivated or have the ability to pay for private tutors. It should also be noted that, overall, two-thirds of adolescents whose parents had no education also engaged private tutors.

Monthly costs for tuition by region show that about three-fifths of the adolescents receiving tutoring said that they had to pay more than Tk1,000, of which $25 \%$ had to pay more than Tk2,000 (Table 3.6). Seventy-five percent of the adolescents from Dhaka North and about 62\% from Dhaka South had to pay more than Tk1000 per month for private tutoring, while this proportion was only 35\% in Gazipur (data not shown). 
Table 3.7: Percentage of currently enrolled adolescents surveyed by private tutoring status and parents' level of education

\begin{tabular}{|l|c|c|c|c|}
\hline \multirow{2}{*}{ Parents' level of education } & \multicolumn{3}{|c|}{ City corporation/area (\%) } & \multirow{2}{*}{ All areas (\%) } \\
\cline { 2 - 4 } & Dhaka North & $\begin{array}{c}\text { Dhaka } \\
\text { South }\end{array}$ & Gazipur & \\
\hline Father's level of education & & & & \\
\hline No education & 58.9 & 79.8 & 59.1 & 66.0 \\
\hline Primary level & 63.0 & 79.9 & 75.7 & 74.5 \\
\hline Secondary incomplete & 75.8 & 82.5 & 82.2 & 80.3 \\
\hline SSC and above & 79.4 & 81.5 & 73.2 & 79.0 \\
\hline Mother's level of education & & & & \\
\hline No education & 56.4 & 80.5 & 63.2 & 66.9 \\
\hline Primary level & 67.7 & 75.4 & 75.4 & 72.9 \\
\hline Secondary incomplete & 77.0 & 84.8 & 77.4 & 80.2 \\
\hline SSC and above & 81.3 & 83.4 & 78.1 & 81.5 \\
\hline N & 868 & 787 & 717 & 2,372 \\
\hline
\end{tabular}

\section{EDUCATIONAL ATTAINMENT/ACHIEVEMENT}

\section{Language and literacy}

Distribution of adolescents by their literacy competencies, sex, age group, and schooling status are presented in Table 3.8. Slightly higher proportions of girls could read Bangla sentences fully compared with the boys, while slightly higher proportions of the boys could read English sentences fully compared with the girls. More adolescents from the younger age group of 12-15 years could read the Bangla sentences, while more adolescents from the older age group of 16-19 years could read English sentences compared with the younger age group. In reading both the Bangla and English sentences, currently enrolled (i.e., in-school) adolescents did significantly better than out-of-school adolescents. Girls and the younger age group did comparatively better in answering the questions on the passage than boys and the older age group, respectively, and in-school adolescents did significantly better than out-of-school adolescents in these items on the passage (Table 3.8) 
Table 3.8: Percentage of adolescents surveyed by literacy competencies, sex, age group, and schooling status

\begin{tabular}{|l|c|c|c|c|c|c|c|}
\hline \multirow{2}{*}{ Literacy item } & \multicolumn{2}{|c|}{ Sex (\%) } & \multicolumn{2}{c|}{ Age group (\%) } & \multicolumn{2}{c|}{$\begin{array}{c}\text { Schooling status } \\
\text { (\%) }\end{array}$} & \multirow{2}{*}{ All (\%) } \\
\cline { 2 - 7 } & Boys & Girls & $\begin{array}{c}12-15 \\
\text { Years }\end{array}$ & $\begin{array}{c}16-19 \\
\text { Years }\end{array}$ & $\begin{array}{c}\text { In- } \\
\text { school }\end{array}$ & $\begin{array}{c}\text { Out-of- } \\
\text { school }\end{array}$ & \\
\hline Reading sentences & & & & & & & \\
\hline $\begin{array}{l}\text { Can read the full Bangla } \\
\text { sentences }\end{array}$ & 86.2 & 86.8 & 87.0 & 86.0 & 95.2 & 67.8 & 86.5 \\
\hline $\begin{array}{l}\text { Can read the full English } \\
\text { sentences }\end{array}$ & 61.3 & 59.8 & 59.6 & 61.6 & 77.7 & 23.5 & 60.5 \\
\hline Reading passage & & & & & & & \\
\hline $\begin{array}{l}\text { Can read the passage within one } \\
\text { minute }\end{array}$ & 43.8 & 44.0 & 40.4 & 47.9 & 58.4 & 12.7 & 43.9 \\
\hline Can read the first five sentences & 62.9 & 62.1 & 62.2 & 62.9 & 79.7 & 25.4 & 62.5 \\
\hline $\begin{array}{l}\text { Can answer the questions on the } \\
\text { passage }\end{array}$ & 8.3 & 12.5 & 9.0 & 12.0 & 14.5 & 1.6 & 10.4 \\
\hline $\mathrm{N}$ & 1,724 & 1,746 & 1,832 & 1,638 & 2,372 & 1,098 & 3,470 \\
\hline
\end{tabular}

Table 3.9 presents the distribution of adolescents by their language/literacy competencies and area. Adolescents who ever enrolled in school were given two Bangla sentences and two English sentences to read, and an English passage with ten sentences to read and comprehend. Slightly less than nine-tenths of the respondents could read the Bangla sentences fully, and this proportion varied according to areas with the highest proportion (90.2\%) in Dhaka North and the lowest (82.8\%) in Gazipur. In the English sentences, three-fifths of the respondents could read the sentences fully, and this proportion varied according to areas, with the highest (73.5\%) in Dhaka North and the lowest (47.4\%) in Gazipur. The respondents were given one minute to read the passage. About $44 \%$ of the respondents could read the passage within the given time, and this proportion was the highest (59.8\%) in Dhaka North and the lowest (32.1\%) in Gazipur. However, $62.5 \%$ of the respondents could read the first sentences of the passage in one minute, and this proportion was found to be the highest (74.8\%) in Dhaka North and the lowest (50.7\%) in Gazipur. Only about $10 \%$ of respondents could comprehend the passage by answering all the questions on it, and the situation was best in Dhaka North and worse in Gazipur. These assessments are roughly similar to an assessment conducted among girls ages 12-19 in three rural districts of Bangladesh under BALIKA and suggest that while Bangla reading levels are similar, the level of English reading and comprehension in urban areas is considerably higher than in the rural study (Amin et al. 2014).

Table 3.9: Percentage of adolescents surveyed who ever attended school by literacy competencies and area of residence

\begin{tabular}{|l|c|c|c|c|}
\hline \multirow{2}{*}{ Literacy item } & \multicolumn{3}{|c|}{ City corporation/area (\%) } & \multirow{2}{*}{ All areas (\%) } \\
\cline { 2 - 5 } & Dhaka North & $\begin{array}{c}\text { Dhaka } \\
\text { South }\end{array}$ & Gazipur & \\
\hline Reading sentences & & & & \\
\hline Can read the full Bangla sentences & 90.2 & 86.5 & 82.8 & 86.5 \\
\hline Can read the full English sentences & 73.5 & 60.7 & 47.4 & 60.5 \\
\hline Reading passage & & & & \\
\hline Can read the passage within one minute & 59.8 & 39.9 & 32.1 & 43.9 \\
\hline Can read the first five sentences in one minute & 74.8 & 62.1 & 50.7 & 62.5 \\
\hline Can answer the questions on the passage & 17.3 & 8.1 & 5.8 & 10.4 \\
\hline $\mathbf{N}$ & 1,153 & 1,157 & 1,160 & 3,470 \\
\hline
\end{tabular}


Performance of the adolescents in language and literacy items tested in the survey increased from the lowest to the highest level of education attained by the respondents (Table 3.10). Among adolescents who completed an SSC degree and above, $97.5 \%$ could read the Bangla sentences fully, and this proportion was $95.6 \%$ for those who studied secondary grades, $84.3 \%$ for primary completers, and only $51.0 \%$ for those who studied primary grades. In the case of reading English sentences, among adolescents who completed the SSC degree and above, 91.9\% could read the sentences fully, and this proportion was $71.8 \%$ for those who studied secondary grades, $33.7 \%$ for primary completers, and only $12.3 \%$ for those who studied primary grades. This trend was found also in all the items on the passage.

Table 3.10: Percentage of adolescents surveyed by literacy competencies and educational level

\begin{tabular}{|l|c|c|c|c|c|}
\hline \multirow{2}{*}{ Literacy item } & \multicolumn{3}{|c|}{ Educational level (\%) } & \multirow{2}{*}{$\begin{array}{c}\text { All levels } \\
\text { (\%) }\end{array}$} \\
\cline { 2 - 6 } & $\begin{array}{c}\text { Primary } \\
\text { incomplete }\end{array}$ & $\begin{array}{c}\text { Primary } \\
\text { complete }\end{array}$ & $\begin{array}{c}\text { Secondary } \\
\text { incomplete }\end{array}$ & $\begin{array}{c}\text { SSC \& } \\
\text { above }\end{array}$ & \\
\hline Reading sentences & & & & & \\
\hline Can read the full Bangla sentences & 51.0 & 84.3 & 95.6 & 97.5 & 86.5 \\
\hline Can read the full English sentences & 12.3 & 33.7 & 71.8 & 91.9 & 60.5 \\
\hline Reading passage & & & & & \\
\hline $\begin{array}{l}\text { Can read the passage within one } \\
\text { minute }\end{array}$ & 5.4 & 13.7 & 51.6 & 77.6 & 43.9 \\
\hline Can read the first five sentences & 12.8 & 35.9 & 74.7 & 92.8 & 62.5 \\
\hline $\begin{array}{l}\text { Can answer the questions on the } \\
\text { passage }\end{array}$ & 0.8 & 3.0 & 10.5 & 23.4 & 10.4 \\
\hline $\mathbf{N}$ & 633 & 401 & 1,753 & 683 & 3,470 \\
\hline
\end{tabular}

\section{Non-language Aptitude test}

Performance in aptitude test items is presented in Table 3.11. The exact questions are shown in Table A3.6 in the Annex. The table presents the distribution of adolescents who ever attended school by their performance in aptitude test, sex, age group, and schooling status. The tests included items on mathematics, logical reasoning, and life skills related to citizenry. Mathematics tests consist of contents such as number characteristics, addition, subtraction, multiplication, division, unit conversion, profit-and-loss calculation, measurement of area, fractions, and geometric-shape identification. Boys and girls performed almost equally in the items on number characteristics, profit-and-loss calculation, and citizenry (Table 3.11). Boys did better than girls in items on addition, subtraction, multiplication, division, unit conversion, and fractions, while girls did better than boys in items on geometric-shape identification and logical reasoning. The younger group ages 12-15 years and the older group ages 16-19 years performed almost equally in the items on number characteristics, addition, and multiplication. The older group did better than the younger group in the items on subtraction, division, unit conversion, profit-and-loss calculation, measurement of area, and fractions, while the younger group did better than the older group only in identification of geometric shapes. Currently-in-school adolescents did far better in all the items than those who were not in school (Table 3.11). 
Table 3.11: Percentage of adolescents surveyed by mathematics and other competencies, sex, age group, and schooling status

\begin{tabular}{|l|c|c|c|c|c|c|c|}
\hline \multirow{2}{*}{ Competency item } & \multicolumn{2}{|c|}{ Sex (\%) } & \multicolumn{2}{c|}{ Age group (\%) } & \multicolumn{2}{c|}{$\begin{array}{c}\text { Schooling status } \\
\text { (\%) }\end{array}$} & \multirow{2}{*}{$\begin{array}{c}\text { All } \\
\text { (\%) }\end{array}$} \\
\cline { 2 - 7 } & Boys & Girls & $\begin{array}{c}12-15 \\
\text { years }\end{array}$ & $\begin{array}{c}16-19 \\
\text { years }\end{array}$ & $\begin{array}{c}\text { In- } \\
\text { school }\end{array}$ & $\begin{array}{c}\text { Out-of- } \\
\text { school }\end{array}$ & \\
\hline Mathematics & & & & & & & \\
\hline Number characteristics (2) & 94.4 & 94.8 & 94.4 & 94.9 & 98.3 & 86.8 & 94.6 \\
\hline Addition (1) & 90.7 & 86.2 & 88.6 & 88.2 & 96.2 & 71.8 & 88.4 \\
\hline Subtraction (3) & 62.6 & 51.6 & 54.9 & 59.5 & 69.7 & 29.7 & 57.1 \\
\hline Multiplication (2) & 70.5 & 65.0 & 68.0 & 67.5 & 83.2 & 34.2 & 67.7 \\
\hline Division (2) & 37.5 & 29.6 & 30.9 & 36.3 & 45.2 & 8.2 & 33.5 \\
\hline Unit conversion (1) & 33.6 & 21.2 & 24.8 & 30.3 & 37.0 & 6.7 & 27.4 \\
\hline Profit-and-loss calculation (1) & 33.9 & 34.4 & 30.0 & 38.8 & 43.6 & 13.8 & 34.1 \\
\hline Measurement of area (1) & 15.5 & 15.9 & 13.7 & 17.9 & 21.8 & 2.6 & 15.7 \\
\hline Fractions (1) & 18.2 & 16.4 & 15.1 & 19.7 & 24.1 & 2.5 & 17.3 \\
\hline Geometric-shape identification (1) & 31.4 & 36.0 & 35.1 & 32.2 & 45.4 & 8.5 & 33.7 \\
\hline Logical reasoning (4) & 63.3 & 73.5 & 67.4 & 69.7 & 77.9 & 48.2 & 68.5 \\
\hline Citizenship awareness (3) & 95.8 & 95.0 & 94.5 & 96.4 & 97.8 & 90.3 & 95.4 \\
\hline N & 1,724 & 1,746 & 1,832 & 1,638 & 2,372 & 1,098 & 3,470 \\
\hline
\end{tabular}

Distribution of adolescents by their mathematics and other competencies and area are presented in Table 3.12. About $95 \%$ of the respondents could solve the items on number characteristics, and the performance on this was almost the same among the adolescents in three areas (See Table A3.6). Slightly less than ninetenths of the respondents could solve the item on addition and this proportion varied according to areas, with the highest (95.0\%) in Dhaka North and the lowest (86.1\%) in Gazipur. About 57\% of the adolescents could solve the items on subtraction and this proportion varied according to areas, with the highest (69.0\%) in Dhaka North and the lowest (46.5\%) in Gazipur. Respondents did better in multiplication than subtraction. About $68 \%$ of the adolescents could solve the items on multiplication and this proportion varied according to areas, with the highest (74.1\%) in Dhaka North and the lowest (60.9\%) in Gazipur. Almost equal proportions of adolescents could solve the items on division and profit-and-loss calculation, and in both cases adolescents from Dhaka North did the best followed by Dhaka South and Gazipur. Slightly more than onefourth of the adolescents could solve the item unit conversion, and as with other items, adolescents from Dhaka North did the best followed by Dhaka South and Gazipur. Among the mathematics items, adolescents did worse on measurement of area and fractions, with only about $16 \%$ and $17 \%$ able to solve the items, respectively. About $34 \%$ of the adolescents could solve the item on identification of geometric shape. More than two-thirds of the respondents could answer correctly the items on logical reasoning, and more than 95\% could answer correctly the items on citizenry. In all the items in the aptitude test, adolescents from Dhaka North did the best followed by Dhaka South and Gazipur (Table 3.12). 
Table 3.12: Percentage of adolescents by their mathematics and other competencies and area of residence

\begin{tabular}{|l|c|c|c|c|}
\hline \multirow{2}{*}{ Competency item } & \multicolumn{3}{|c|}{ City corporation/area (\%) } & \multirow{2}{*}{ All areas (\%) } \\
\cline { 2 - 4 } & Dhaka North & $\begin{array}{c}\text { Dhaka } \\
\text { South }\end{array}$ & Gazipur & \\
\hline Mathematics & & & & \\
\hline Number characteristics (2) & 95.2 & 94.3 & 94.4 & 94.6 \\
\hline Addition (1) & 95.0 & 88.8 & 86.1 & 88.4 \\
\hline Subtraction (3) & 69.0 & 55.7 & 46.5 & 57.1 \\
\hline Multiplication (2) & 74.1 & 68.2 & 60.9 & 67.7 \\
\hline Division (2) & 45.0 & 32.3 & 23.1 & 33.5 \\
\hline Unit conversion (1) & 39.0 & 23.2 & 20.0 & 27.4 \\
\hline Profit-and-loss calculation (1) & 46.3 & 32.1 & 24.1 & 34.1 \\
\hline Measurement of area (1) & 21.4 & 15.4 & 10.3 & 15.7 \\
\hline Fractions (1) & 24.6 & 15.6 & 11.6 & 17.3 \\
\hline Geometric-shape identification (1) & 37.6 & 35.1 & 28.5 & 33.7 \\
\hline Logical reasoning (4) & 76.6 & 64.7 & 64.1 & 68.5 \\
\hline Citizenship awareness (3) & 97.7 & 94.0 & 94.5 & 95.4 \\
\hline N & 1,153 & 1,157 & 1,160 & 3,470 \\
\hline
\end{tabular}

Performance of the adolescents in aptitude test items increased in all the items from the lowest to the highest level of education attained by the respondents (Table 3.13). The difference between the performances of adolescents who completed SSC and above degrees and who did not complete primary education in different items in the aptitude test ranged from 14-70 percentile points. In all the items, adolescents who completed SSC and above degrees did the best followed by those who studied secondary grades, those who completed primary education, and those who studied primary grades (Table 3.13).

Table 3.13: Percentage of adolescents surveyed by nonlanguage aptitude tests and educational level

\begin{tabular}{|l|c|c|c|c|c|}
\hline \multirow{2}{*}{ Competency item } & \multicolumn{3}{|c|}{ Educational level (\%) } & \multirow{2}{*}{$\begin{array}{c}\text { All levels } \\
\text { (\%) }\end{array}$} \\
\cline { 2 - 5 } & $\begin{array}{c}\text { Primary } \\
\text { incomplete }\end{array}$ & $\begin{array}{c}\text { Primary } \\
\text { complete }\end{array}$ & $\begin{array}{c}\text { Secondary } \\
\text { incomplete }\end{array}$ & $\begin{array}{c}\text { SSC \& } \\
\text { above }\end{array}$ & \\
\hline Mathematics & & & & & \\
\hline Number characteristics (2) & 80.4 & 93.0 & 98.6 & 98.7 & 94.6 \\
\hline Addition (1) & 63.0 & 82.5 & 95.0 & 98.5 & 88.4 \\
\hline Subtraction (3) & 17.4 & 42.4 & 64.8 & 82.6 & 57.1 \\
\hline Multiplication (2) & 23.7 & 49.6 & 77.8 & 93.4 & 67.7 \\
\hline Division (2) & 5.1 & 15.0 & 37.4 & 60.6 & 33.5 \\
\hline Unit conversion (1) & 4.9 & 12.5 & 30.4 & 49.3 & 27.4 \\
\hline Profit-and-loss calculation (1) & 7.1 & 17.5 & 36.7 & 62.5 & 34.1 \\
\hline Measurement of area (1) & 0.8 & 6.7 & 16.7 & 32.2 & 15.7 \\
\hline Fractions (1) & 1.9 & 6.5 & 18.4 & 34.8 & 17.3 \\
\hline Geometric-shape identification (1) & 4.6 & 19.2 & 40.5 & 51.8 & 33.7 \\
\hline Logical reasoning (4) & 38.9 & 59.9 & 73.9 & 87.0 & 68.5 \\
\hline Citizenship awareness (3) & 84.7 & 95.0 & 97.9 & 99.3 & 95.4 \\
\hline $\mathrm{N}$ & 633 & 401 & 1,753 & 683 & 3.470 \\
\hline
\end{tabular}




\section{SUMMARY AND CONCLUSIONS}

Adolescent girls are more likely to drop out of school than adolescent boys in the three study areas of the Dhaka metropolitan area. For both boys and girls, looking after siblings is a primary reason for dropping out of school. Marriage is a more important reason for school dropout for girls than for boys. Concerns for safety are important, but competing demands for looking after siblings and poor parental motivation for educating adolescents (parent did not want) are equally important for boys and girls. Boys are twice as likely as girls to say they dropped out because of a lack of interest. About $13 \%$ of all adolescents surveyed repeated a grade. Just fewer than $50 \%$ of those who repeated a grade did so because they did not pass examinations in the previous grade. Overall the attendance rate in schools is high, with $86 \%$ reporting they attended school on the last day the school was in session.

Parents appear to invest considerably in private tutoring for boys and girls, with girls being slightly more likely to be tutored than boys. Mathematics and English are two subjects in which students receive tutoring help.

Boys and girls who are currently enrolled perform similarly in school. Girls who are in school are slightly more likely to be in higher grades and they are also likely to quit school at higher levels than boys. Boys and girls, and older and younger adolescents performed similarly in language and aptitude. In general, English language aptitude is poorer than aptitude in Bangla, the language spoken at home for the majority of girls. However, competencies in mathematics are assessed to be poor overall. While it is expected that adolescents with incomplete primary schooling will not be able to answer questions on fraction manipulation, it is striking that less than one-third of adolescents with SSC or greater education were able to answer these questions correctly.

The largest differentials in learning outcomes are found by whether the adolescent is currently in school. Relative to school enrollment, sex- and age-related differentials are not significant. Levels of schooling completed are also related to differential learning outcomes. 


\section{ANNEX FOR CHAPTER 3}

\section{School Experience}

\section{Amenities and school quality}

Table A3.1 presents the distribution of the currently enrolled adolescents by the amenities in their schools for indicators that were shown to vary by area. In most respects, such as sitting arrangement, electricity, fan, and adequate light, the vast majority of students reported similar school characteristics. More than ninetenths of the adolescents mentioned that they were to sit on benches that are not appropriate for arranging group work (data not shown).

Table A3.1 presents the distribution of the currently enrolled adolescents by some other amenities in their schools. Slightly less than half of the respondents were enrolled in mixed-sex co-educational schools, and this proportion was the highest (69.8\%) in Gazipur and the lowest (28.0\%) in Dhaka South. Less than half of the currently enrolled adolescents mentioned that computer was taught in their schools, with the lowest proportion (30.5\%) in Gazipur. Although more than three-fifths had computer laboratories in their schools, with the lowest proportion (39.9\%) in Gazipur, less than one-third mentioned that any student could use the computer laboratory. About $12 \%$ of the adolescents indicated that there was no library in their schools, with the worse situation in Gazipur in this regard. Slightly less than three-fifths of the adolescents mentioned that there were libraries in their schools and that they used them, while about $30 \%$ of the adolescents had a library in their schools but they did not use it. Use of the library varied according to areas, with the situation best in Dhaka North. More than half of the respondents either had no playground in their schools or they were not in a co-educational school. Only about $14 \%$ of the adolescents in co-educational schools said that the school playground was used equally by boys and girls, and 30\% mentioned that school playgrounds were mostly used by the boys. These proportions varied according to areas. In regard to drinking water facilities in the schools, about $7 \%$ of the respondents mentioned there was no drinking water facility in their schools and most of the cases in this regard were in Dhaka North and Dhaka South. Most of the respondents from Dhaka North (74.0\%) and Dhaka South (53.7\%) mentioned filtered water, which is more or less deemed to be safe, while most of the adolescents from Gazipur (47.6\%) mentioned tap water, which is not particularly safe in Bangladesh's cities. Overall, the situation of the safe drinking water facility in the schools was better in Dhaka North, compared with the other two areas. 
Table A3.1: Percentage of currently enrolled adolescents surveyed by selected school amenities and area of residence

\begin{tabular}{|c|c|c|c|c|}
\hline \multirow[t]{2}{*}{ Basic amenities } & \multicolumn{3}{|c|}{ City corporation/area (\%) } & \multirow{2}{*}{$\begin{array}{c}\text { All areas } \\
(\%)\end{array}$} \\
\hline & $\begin{array}{l}\text { Dhaka } \\
\text { North }\end{array}$ & $\begin{array}{l}\text { Dhaka } \\
\text { South }\end{array}$ & Gazipur & \\
\hline Enrolled in co-educational school & 50.9 & 28.0 & 69.8 & 49.7 \\
\hline Taught computer in the school & 58.0 & 51.4 & 30.5 & 47.5 \\
\hline Computer laboratory in the school & 73.9 & 65.5 & 39.9 & 60.9 \\
\hline $\mathrm{N}$ & 868 & 787 & 717 & 2,372 \\
\hline $\begin{array}{l}\text { Any student can use the computer } \\
\text { laboratory }\end{array}$ & 31.8 & 30.6 & 30.4 & 31.1 \\
\hline $\mathrm{N}$ & 642 & 516 & 286 & 1,444 \\
\hline \multicolumn{5}{|l|}{ Use of library in the school } \\
\hline Yes & 69.9 & 56.5 & 51.2 & 59.9 \\
\hline No & 27.3 & 28.3 & 29.5 & 28.3 \\
\hline No library in the school & 28 & 15.2 & 19.3 & 11.8 \\
\hline \multicolumn{5}{|l|}{ Use of playground } \\
\hline Mostly boys & 30.0 & 14.1 & 48.1 & 30.2 \\
\hline Mostly girls & 0.0 & 1.1 & 0.6 & 0.5 \\
\hline Equal & 15.1 & 11.3 & 16.2 & 14.2 \\
\hline Not applicable & 54.9 & 73.4 & 35.1 & 55.0 \\
\hline \multicolumn{5}{|l|}{ Drinking-water facility } \\
\hline Tube well & 5.2 & 10.0 & 24.8 & 12.7 \\
\hline Filtered water & 74.0 & 53.7 & 18.5 & 50.5 \\
\hline Tap water & 9.4 & 24.0 & 47.6 & 25.8 \\
\hline Boiled water & 1.4 & 0.5 & 1.0 & 1.0 \\
\hline No facility & 8.9 & 8.9 & 1.3 & 6.6 \\
\hline Others & 1.1 & 2.8 & 6.8 & 3.4 \\
\hline $\mathrm{N}$ & 868 & 787 & 717 & 2,372 \\
\hline
\end{tabular}

\section{SCHOOL EXPERIENCE}

Participation in all group sports was higher among boys and the older age group than among girls and the younger age group (Table A3.2). The rate of participation in co-curricular activities and arranging meetings with parents by the school was found higher for boys and the younger age group compared with the girls and older age group, respectively. 
Table A3.2: Percentage of currently enrolled adolescents by selected school experience indicators, sex, and age group

\begin{tabular}{|l|c|c|c|c|}
\hline \multirow{2}{*}{ School experience } & \multicolumn{2}{|c|}{ Sex (\%) } & \multicolumn{2}{c|}{ Age group (\%) } \\
\cline { 2 - 5 } & $\begin{array}{c}\text { Boys } \\
\mathrm{N}=1,241\end{array}$ & $\begin{array}{c}\text { Girls } \\
\mathrm{N}=1,131\end{array}$ & $\begin{array}{c}12-15 \\
\text { years } \\
\mathrm{N}=1,511\end{array}$ & $\begin{array}{c}16-19 \text { years } \\
\mathrm{N}=861\end{array}$ \\
\hline Participated in group sports in last one year* & & & & \\
\hline Football & 40.6 & 3.2 & 22.2 & 23.7 \\
\hline Cricket & 74.9 & 4.7 & 41.2 & 41.8 \\
\hline Volleyball/handball & 4.3 & 2.9 & 3.0 & 4.8 \\
\hline Ha-du-du & 3.3 & 1.8 & 2.6 & 2.4 \\
\hline Accompanied by anyone to school & 6.7 & 22.5 & 17.9 & 7.8 \\
\hline & & & & \\
\hline Participated in co-curricular activities regularly & 20.8 & 16.4 & 19.6 & 17.2 \\
\hline Type of co-curricular activities like most & & & & \\
\hline Reciting poems & 29.7 & 21.8 & 28.4 & 22.5 \\
\hline Debate & 18.9 & 10.1 & 11.5 & 22.5 \\
\hline Dance & 1.5 & 16.5 & 8.1 & 7.3 \\
\hline Sports & 31.7 & 12.2 & 24.3 & 21.9 \\
\hline Singing & 8.5 & 24.5 & 15.2 & 15.2 \\
\hline Drama & 1.5 & 4.8 & 2.9 & 3.3 \\
\hline Others & 8.1 & 10.1 & 9.8 & 7.3 \\
\hline $\begin{array}{l}\text { School arranged meetings with parents } \\
\text { regularly }\end{array}$ & 55.7 & 52.0 & 57.1 & 48.3 \\
\hline N & 1,241 & 1,131 & 1,511 & 861 \\
\hline
\end{tabular}

*Multiple responses.

Table A3.3 presents the distribution of the currently enrolled adolescents by selected school experiences and area. Major sports that students participated in last year included football, cricket, volleyball/handball, and a traditional team sport called ha-du-du. Among boys, most participated in cricket (40.6\%) and football $(74.9 \%)$ and these proportions varied according to areas. 
Table A3.3: Percentage of currently enrolled adolescents surveyed by selected school experiences and area of residence

\begin{tabular}{|l|c|c|c|c|}
\hline \multirow{2}{*}{ School experience } & \multicolumn{2}{|c|}{ Sex (\%) } & \multicolumn{2}{c|}{ Age group (\%) } \\
\cline { 2 - 5 } & Boys & Girls & $\begin{array}{c}12-15 \\
\text { years }\end{array}$ & $16-19$ years \\
\hline Participated in group sports in last one year* & & & & \\
\hline Football & 40.6 & 3.2 & 22.2 & 23.7 \\
\hline Cricket & 74.9 & 4.7 & 41.2 & 41.8 \\
\hline Volleyball/handball & 4.3 & 2.9 & 3.0 & 4.8 \\
\hline Ha-du-du & 3.3 & 1.8 & 2.6 & 2.4 \\
\hline Accompanied by anyone to school & 6.7 & 22.5 & 17.9 & 7.8 \\
\hline School arranged meetings with parents regularly & 55.7 & 52.0 & 57.1 & 48.3 \\
\hline Participated in co-curricular activities regularly & 20.8 & 16.4 & 19.6 & 17.2 \\
\hline N & 1,241 & 1,131 & 1,511 & 861 \\
\hline Type of co-curricular activities like most & & & & \\
\hline Reciting poems & 29.4 & 22.0 & 28.4 & 22.5 \\
\hline Debate & 18.9 & 10.2 & 11.5 & 22.5 \\
\hline Dance & 1.5 & 16.7 & 8.1 & 7.3 \\
\hline Sports & 31.7 & 11.8 & 24.3 & 21.9 \\
\hline Singing & 8.5 & 24.7 & 15.2 & 15.2 \\
\hline Drama & 1.5 & 4.8 & 2.9 & 3.3 \\
\hline Others & 8.1 & 9.8 & 9.8 & 7.3 \\
\hline N & 258 & 186 & 296 & 148 \\
\hline
\end{tabular}

*Multiple responses.

\section{Classroom experience}

Distribution of currently enrolled adolescents by selected classroom experiences and area are presented in Table A3.4. Students' participation in classroom activities, praising by teachers on good performance, and absence of negative behavior by the teachers are considered to be qualities of the pedagogic practices in the classroom. About $95 \%$ of the currently enrolled adolescents mentioned that they could participate in classroom activities. More than four-fifths of the adolescents said they could express their opinion followed by asking questions of the teachers (78.0\%), participating in group discussion (29.1\%), and participating in group work/project work (24.7\%). Most adolescents reported that they have been praised by teachers for good performance. About $7 \%$ of the adolescents said that the teachers praised students every day for good performance, $84.9 \%$ mentioned that this happened some of the time, and $7.7 \%$ mentioned that it never happened in the classroom. About $14 \%$ to $33 \%$ of students mentioned some kind of negative behavior by teachers, including teachers teasing students based on their intelligence (13.9\%), scolding students if they could not understand the lesson (23.1\%), and teasing students for general cleanliness (33.3\%). 
Table A3.4: Percentage of currently enrolled adolescents by selected classroom experiences and area of residence

\begin{tabular}{|l|c|c|c|c|}
\hline \multirow{2}{*}{ Classroom experience } & \multicolumn{2}{|c|}{ City corporation/area (\%) } & \multirow{2}{*}{ All areas (\%) } \\
\cline { 2 - 4 } & Dhaka North & $\begin{array}{c}\text { Dhaka } \\
\text { South }\end{array}$ & Gazipur & \\
\hline $\begin{array}{l}\text { Students can participate/express their opinion } \\
\text { while teachers teach }\end{array}$ & 96.7 & 95.3 & 93.6 & \multirow{2}{*}{95.3} \\
\hline Type of activities students can participate in* & & & & \\
\hline Expressing opinion & 88.5 & 86.0 & 78.8 & 84.7 \\
\hline Group discussion & 31.1 & 32.6 & 22.7 & 29.1 \\
\hline Group work/project work & 28.6 & 23.4 & 21.1 & 24.7 \\
\hline Asking questions of the teacher & 84.5 & 70.7 & 78.0 & 78.0 \\
\hline Praised by teacher/s for good performance & & & & \\
\hline Every day & 6.3 & 7.1 & 8.9 & 7.4 \\
\hline Sometimes & 86.2 & 86.5 & 81.5 & 84.9 \\
\hline Never & 7.5 & 6.3 & 9.6 & 7.7 \\
\hline $\begin{array}{l}\text { Teachers scold students if they don't } \\
\text { understand the lesson }\end{array}$ & 15.4 & 30.4 & 24.4 & 23.1 \\
\hline $\begin{array}{l}\text { Teachers tease students based on their } \\
\text { intelligence }\end{array}$ & 8.6 & 16.9 & 17.0 & 13.9 \\
\hline $\begin{array}{l}\text { Teachers tease students for general } \\
\text { cleanliness }\end{array}$ & 24.3 & 38.5 & 38.4 & 33.3 \\
\hline $\mathbf{N}$ & 868 & 787 & 717 & 2372 \\
\hline
\end{tabular}

*Multiple responses.

Table A3.5 presents the distribution of currently enrolled adolescents by selected classroom experiences, sex, and age group. Overall, more girls than boys and more older age groups than younger age groups could participate in classroom activities (Table A3.5). More girls than boys mentioned that the students could express their opinion and participate in group discussion, while more boys than girls mentioned that the students could participate in group work/project work and ask questions of teachers. More adolescents from the older age group than from the younger age group mentioned students could participate in all four classroom activities. Girls faced never being praised by the teachers more than boys. More boys mentioned teachers' negative behavior than the girls, and the younger age group mentioned teachers' negative behavior more than the older age group (Table A3.5). 
Table A3.5: Percentage of currently enrolled adolescents by selected classroom experiences, sex, and age group

\begin{tabular}{|l|c|c|c|c|}
\hline \multirow{2}{*}{ Classroom experience } & \multicolumn{2}{|c|}{ Sex (\%) } & \multicolumn{2}{c|}{ Age group (\%) } \\
\cline { 2 - 5 } & Boys & Girls & $\begin{array}{c}12-15 \\
\text { years }\end{array}$ & $16-19$ years \\
\hline $\begin{array}{l}\text { Students can participate/express their opinion } \\
\text { while teachers teach }\end{array}$ & 94.5 & 96.1 & 94.9 & 95.9 \\
\hline Type of activities students can participate in* & & & & \\
\hline Expressing opinion & 84.1 & 85.3 & 83.3 & 87.0 \\
\hline Group discussion & 28.2 & 30.1 & 27.0 & 32.6 \\
\hline Group work/project work & 26.0 & 23.2 & 23.1 & 27.3 \\
\hline Asking questions of teacher & 81.9 & 73.7 & 77.1 & 79.4 \\
\hline Praised by teacher/s for good performance & & & & \\
\hline Every day & 8.5 & 6.1 & 8.1 & 6.2 \\
\hline Sometimes & 84.6 & 85.1 & 84.2 & 86.1 \\
\hline Never & 6.9 & 8.7 & 7.7 & 7.7 \\
\hline $\begin{array}{l}\text { Teachers scold students if they don't } \\
\text { understand the lesson }\end{array}$ & 24.0 & 22.1 & 26.3 & 17.5 \\
\hline $\begin{array}{l}\text { Teachers tease students based on their } \\
\text { intelligence }\end{array}$ & 15.6 & 12.1 & 15.7 & 10.8 \\
\hline Teachers tease students for general cleanliness & 37.9 & 28.2 & 36.5 & 27.5 \\
\hline N & 1,241 & 1,131 & 1,511 & 861 \\
\hline
\end{tabular}

*Multiple responses. 
Table A3.6: Question/s under each competency category in aptitude test

\begin{tabular}{|c|c|}
\hline Competency item & Question/s \\
\hline \multicolumn{2}{|l|}{ Mathematics } \\
\hline \multirow[t]{2}{*}{ Number characteristics (2) } & $\begin{array}{l}\text { 1. Write the missing number } \\
14,15,--, 17,--, 19,20,---,--, 23\end{array}$ \\
\hline & $\begin{array}{l}\text { 2. Write these numbers in order starting from the biggest number to the } \\
\text { smallest } \\
8,10,5,11 \text {, and } 4 \text {. }\end{array}$ \\
\hline Addition (1) & $137+57$ \\
\hline \multirow[t]{3}{*}{ Subtraction (3) } & $\begin{array}{l}\text { 1. Subtraction } \\
18-7\end{array}$ \\
\hline & $\begin{array}{l}\text { 2. You have Tk75 and you want to buy a pen that costs } 67 \text { taka. How } \\
\text { much change would you get? }\end{array}$ \\
\hline & 3. Ayesha had 3,000 eggs. She sold 2,108 eggs. How many were left? \\
\hline \multirow[t]{2}{*}{ Multiplication (2) } & $\begin{array}{l}\text { 1. Multiplication } \\
23 \times 12\end{array}$ \\
\hline & 2. Each banana costs Tk8. How much would 3 bananas cost? \\
\hline \multirow[t]{2}{*}{ Division (2) } & $\begin{array}{l}\text { 1. Division } \\
459 \div 3\end{array}$ \\
\hline & $\begin{array}{l}\text { 2. The product of two factors is } 255 \text {. If one of the factors is } 15 \text {, what is } \\
\text { the other factor? }\end{array}$ \\
\hline Unit conversion (1) & 1. Change 4,600 grams to kilograms and grams \\
\hline Profit-and-loss calculation (1) & $\begin{array}{l}\text { 1. A cell phone was bought for Tk10,000 and later sold at } 12,000 \text { taka. } \\
\text { What was the profit percent? }\end{array}$ \\
\hline Measurement of area (1) & 1. Find the area of a square whose side is $14 \mathrm{~cm}$ long. \\
\hline Fraction (1) & 1. Subtract $11 / 8$ from the sum of $2 \frac{1}{4}$ and $3 / 4$. \\
\hline Geometric-shape identification (1) & $\begin{array}{l}\text { Which of the following quadrilaterals is not a parallelogram? } \\
\text { (options include square, rectangle, rhombus and trapezoid) }\end{array}$ \\
\hline \multirow[t]{4}{*}{ Logical reasoning (4) } & $\begin{array}{l}\text { 1. What should the missing number be in the series? } \\
20,30,40, \ldots, 60,70\end{array}$ \\
\hline & $\begin{array}{l}\text { 2. In the four items shown below, three are of the same class and one } \\
\text { is different. Which of the following items does not belong to the list? } \\
\begin{array}{llll}\text { a) Mango } & \text { b) Apple } & \text { c) Eggplant } & \text { 4) Orange }\end{array}\end{array}$ \\
\hline & $\begin{array}{l}\text { 3. Three items listed below are similar and one is different. Which one } \\
\text { is different? } \\
\begin{array}{ll}\text { a) b) } \\
\text { c) }\end{array}\end{array}$ \\
\hline & $\begin{array}{l}\text { 4. Sky is to airplane as sea is to? } \\
\text { Sky: Airplane, Sea: .............. ? } \\
\text { a) Sailor } \\
\text { b) Tree } \\
\text { c) Ship } \\
\text { d) Tiger }\end{array}$ \\
\hline \multirow[t]{3}{*}{ Citizenship awareness (3) } & 1. What is the (Bangladesh) national anthem? \\
\hline & 2. What is the name of the capital of Bangladesh? \\
\hline & 3. Who is the current prime minister of the country? \\
\hline
\end{tabular}




\title{
Chapter 4 \\ Sexual and Reproductive Health, Marriage, and Childbearing
}

\author{
MITUL DUTTA, SYEDA REZWANA AKHTER, AND SHUCHI KARIM
}

In this chapter, data related to reproductive health and family planning knowledge were analyzed by age, sex, and marital status. The chapter includes a section on marriage timing and characteristics. The results of this section are organized according to adolescents' sexual and reproductive health knowledge, practices, and access to SRHR information and services.

Previous studies suggest that child marriage affects a far greater number of adolescent females than adolescent males. Child marriage is associated with a high likelihood of complications in pregnancy and childbirth-among the leading causes of death for girls between the ages of 15 and 19 worldwide.

Insufficient control over their own fertility leads many adolescent girls to resort to unsafe abortions and risk serious injury or death (UNICEF 2011).

Although it is widely recognized that information and knowledge can facilitate the adoption of safe sex behaviors (National Plan of Action 2013), lack of knowledge and information among adolescents about SRHR leading to unsafe sex, unsafe abortion, and other risky behavior with negative consequences for health is well documented in urban Bangladesh (Rahman, Hossain, and Amin 2012). Poor access to information is associated with the lack of mobility, child marriage, and a general culture of silence and shame around these topics. Addressing adolescent health is a challenge and opportunity for parents and educators who frequently are unwilling or unable to provide complete, accurate, age-appropriate reproductive health information to young people. This is often due to their discomfort about the subject or the misconception that providing the information will encourage increased sexual activity.

Among adolescents, the experience of girls and boys differs widely. Early marriage is probably the single most important factor. The median age of marriage among 20-49-year-old ever married women is 15.8 years (Nation Plan of Action 2013) and data from BDHS 2011 suggests that among women ages 20-49, 74 percent married by age 18 and 86 percent married by age 20 . Women who marry early, on average, are more likely to have their first child at a young age and give birth to more children overall, contributing to higher fertility (NIPORT, Mitra, and Associates, and ICF International 2013).

A qualitative needs assessment exercise undertaken by BIED, BRACU (2012) found that adolescent girls and boys were insufficiently informed or misinformed about sexual and reproductive health and rights because of lack of information from parents or schoolteachers. Both girls and boys displayed some limited knowledge on AIDS, but no awareness of other sexually transmitted infections. Similarly, Rahman, Hossain, and Amin (2012) confirmed that in Dhaka slums, among girls and women aged 15-19, knowledge about sexual and reproductive health and rights issues is inadequate in terms of sexual rights, reproductive health rights, period of menstrual cycle when one can get pregnant, adverse effects to newborns of teenage pregnancies, emergency contraceptives, sexually transmitted infections, menstruation regulation, and about where sexual health services are available.

Table 4.1 shows the percentage of female respondents who said they knew (what to expect) about menstruation before they first experienced it. A little less than half the respondents overall said they had some knowledge before they first experienced it and a similar percentage reported using sanitary pads. Most of the rest used cloth. These responses were highest in Dhaka North and lowest in Gazipur and consistent 
with a pattern of behavior that suggests knowledge of menstruation and management patterns are generally better among adolescents who are relatively better off.

Table 4.1: Knowledge of menstruation and management among adolescent girls

\begin{tabular}{|l|r|r|r|r|}
\hline \multirow{2}{*}{} & \multicolumn{2}{|c|}{ City corporation/area (\%) } & \multirow{2}{*}{$\begin{array}{c}\text { All areas } \\
\text { (\%) }\end{array}$} \\
\cline { 2 - 5 } & Dhaka North & $\begin{array}{c}\text { Dhaka } \\
\text { South }\end{array}$ & \multicolumn{1}{c|}{ Gazipur } & \\
\hline Knew about menstruation before first period & & & & \\
\hline Yes & 51.1 & 48.5 & 46.3 & 48.7 \\
\hline No & 48.6 & 50.9 & 53.5 & 51.0 \\
\hline No answer & 0.3 & 0.6 & 0.2 & 0.3 \\
\hline N & 570 & 530 & 550 & 1,650 \\
\hline Managing menstrual bleeding & & & & \\
\hline Sanitary pad & 55.9 & 57.3 & 30.5 & 47.9 \\
\hline Cotton & 0.9 & 1.7 & 1.1 & 1.2 \\
\hline Cloth & 42.5 & 40.0 & 67.3 & 50.0 \\
\hline Others & 0.7 & 1.0 & 1.1 & 0.9 \\
\hline N & 571 & 525 & 548 & 1,644 \\
\hline
\end{tabular}

Table 4.2 shows reports of mental/emotional changes associated with the experience of puberty. Girls and boys associated a list of physical experiences that varied by sex-boys were more likely to identify increased sexual awareness and desires while girls were more likely to cite changing interest, stress, confusion as changes associated with puberty.

Table 4.2: Mental /emotional changes experienced with puberty by area of residence and sex

\begin{tabular}{|l|l|l|l|l|l|l|l|}
\hline \multirow{2}{*}{$\begin{array}{l}\text { Mental changes } \\
\text { experienced by } \\
\text { boys/girls in } \\
\text { adolescence period* }\end{array}$} & \multicolumn{2}{l|l|l|l|}{ Dhaka North (\%) } & \multicolumn{2}{l|}{ Dhaka South (\%) } & \multicolumn{2}{l|}{ Gazipur (\%) } & All areas (\%) \\
\cline { 2 - 8 } & Boys & Girls & Boys & Girls & Boys & Girls & \\
\hline Change in interests & 61.9 & 68.3 & 56.6 & 50.8 & 52.6 & 50.5 & 56.8 \\
\hline Increased sexuality & 30.4 & 23.5 & 23.9 & 14.6 & 23.0 & 17.1 & 22.1 \\
\hline Greater stress & 57.2 & 58.3 & 45.3 & 65.4 & 49.5 & 59.3 & 55.9 \\
\hline Greater confusion & 37.9 & 46.2 & 33.8 & 42.0 & 27.1 & 44.1 & 38.6 \\
\hline Others & 2.7 & 3.3 & 5.1 & 4.0 & 5.5 & 3.2 & 4.0 \\
\hline Don't Know & 5.2 & 5.5 & 9.9 & 7.4 & 11.7 & 5.2 & 7.5 \\
\hline $\mathrm{N}$ & 596 & 600 & 574 & 595 & 582 & 592 & 3.539 \\
\hline
\end{tabular}

*Multiple Responses. 
Table 4.3: Percentage of adolescents by their knowledge about menstrual regulation, sex, and marital status

\begin{tabular}{|l|l|l|l|l|}
\hline \multirow{2}{*}{} & \multicolumn{2}{l|}{ Marital status } \\
\cline { 2 - 5 } & \multicolumn{2}{l|}{ Ever married (\%) } & \multicolumn{2}{l|}{ Never married (\%) } \\
\hline Have you ever heard of MR? & 61.2 & 22.3 & \multicolumn{2}{l|}{} \\
\hline $\mathrm{N}$ & 394 & Girls & Boys & Girls \\
\hline $\begin{array}{l}\text { What do you think is the purpose of } \\
\text { doing MR?* }\end{array}$ & Boys & 29 & 64. & 49.6 \\
\hline Regularize menstruation & 30 & 87.9 & 33.9 & 68.8 \\
\hline Abort fetus & 40 & 1.7 & 3.5 & 4 \\
\hline Other reasons & 30 & 231 & 115 & 250 \\
\hline N & 10 & & \\
\hline
\end{tabular}

* Multiple responses.

Knowledge of menstrual regulation (MR) varies widely among adolescents. In Bangladesh, abortion is technically illegal except for limited circumstances, but MR services are widely used to end a pregnancy. Table 4.3 shows that $61 \%$ of married adolescents have any knowledge of MR, compared to $22 \%$ among never married adolescents. Around $88 \%$ of married girls know that MR is a practice to abort a fetus and only $29 \%$ think it is a procedure to otherwise regularize menstruation, whereas among married boys $30 \%$ said it is used to restore menstruation and for other reasons, and $40 \%$ know MR is a procedure to abort. Among never-married adolescents, MR information is considerably lower and sex differentials show that girls are generally more aware that MR is a procedure commonly used to abort a fetus. Around $69 \%$ of the nevermarried adolescent girls have thought about the necessity of MR for abortion and $49.6 \%$ as support for regularizing menstruation, which is the opposite for boys (34\% and $64 \%$, respectively).

Table 4.4: Perception of problems caused by teenage pregnancy, by sex, age group, and marital status (multiple responses)

\begin{tabular}{|c|c|c|c|c|c|c|}
\hline \multirow[b]{2}{*}{$\begin{array}{l}\text { Perception of } \\
\text { teenage } \\
\text { pregnancy }\end{array}$} & \multicolumn{2}{|c|}{ Sex (\%) } & \multicolumn{2}{|c|}{ Age group (\%) } & \multicolumn{2}{|c|}{ Marital status (\%) } \\
\hline & Boys & Girls & $\begin{array}{l}12-15 \\
\text { years }\end{array}$ & $\begin{array}{l}16-19 \\
\text { years }\end{array}$ & Ever married & $\begin{array}{l}\text { Never } \\
\text { married }\end{array}$ \\
\hline $\begin{array}{l}\text { Health risk to } \\
\text { mother }\end{array}$ & 73.3 & 84.0 & 70.7 & 87.6 & 90.5 & 77.3 \\
\hline Health risk to baby & 63.2 & 74.3 & 60.0 & 78.5 & 80.2 & 67.3 \\
\hline $\begin{array}{l}\text { Education might } \\
\text { get stopped }\end{array}$ & 22.2 & 29.9 & 24.6 & 27.6 & 29.6 & 25.6 \\
\hline $\begin{array}{l}\text { May not be able to } \\
\text { continue working }\end{array}$ & 1.9 & 1.5 & 1.0 & 2.5 & 1.5 & 1.7 \\
\hline $\mathrm{N}$ & 1,782 & 1,803 & 1,881 & 1,704 & 398 & 3,187 \\
\hline
\end{tabular}

*Multiple responses. 
Table 4.4 reflects adolescents' views regarding the problems caused by teenage pregnancy. It was found that boys and girls alike think of health risks to the mother and child as the major problem of teenage pregnancy. Girls more than boys mentioned health risk and were also more likely to identify education and discontinuation of education as major problems.

Table 4.5: Percentage of adolescents by knowledge of HIV/AIDS and STDs and how HIV/AIDS is spread, by marital status and sex

\begin{tabular}{|c|c|c|c|c|c|}
\hline & & \multicolumn{4}{|c|}{ Marital status of the adolescent } \\
\hline & & \multicolumn{2}{|c|}{ Ever married (\%) } & \multicolumn{2}{|c|}{ Never married (\%) } \\
\hline \multicolumn{2}{|c|}{ Ever heard of HIV/AIDS (Yes) } & \multicolumn{2}{|l|}{90.3} & \multicolumn{2}{|l|}{91.9} \\
\hline \multicolumn{2}{|c|}{ Ever heard of syphilis/ gonorrhea (Yes) } & \multicolumn{2}{|l|}{10.9} & \multicolumn{2}{|l|}{21.4} \\
\hline \multicolumn{2}{|l|}{$\mathbf{N}$} & \multicolumn{2}{|l|}{388} & \multicolumn{2}{|l|}{1,669} \\
\hline \multicolumn{2}{|c|}{ Cause for spread of HIV/AIDS* } & Boys (\%) & Girls (\%) & Boys (\%) & Girls (\%) \\
\hline \multicolumn{2}{|c|}{ Unprotected intercourse (Yes) } & 59.1 & 55.0 & 65.4 & 65.4 \\
\hline \multicolumn{2}{|c|}{ Multiple sexual partners (Yes) } & 68.2 & 51.2 & 52.3 & 58.2 \\
\hline \multicolumn{2}{|c|}{ Blood transfusion HIV patient (Yes) } & 63.6 & 57.2 & 69.8 & 73.9 \\
\hline \multicolumn{2}{|c|}{ Using same syringe as HIV patient (Yes) } & 59.1 & 54.5 & 66.3 & 69.3 \\
\hline \multicolumn{2}{|l|}{ Sleep in same bed (Yes) } & 0 & 2.1 & 1.0 & 1.7 \\
\hline \multicolumn{2}{|c|}{ Sharing utensils while eating (Yes) } & 0 & 2.1 & 1.1 & 1.1 \\
\hline Sharing clothes & Yes & 0 & 1.8 & .9 & .8 \\
\hline Sneezing/coughing & Yes & 4.5 & 1.5 & .3 & .9 \\
\hline Sharing toilet & Yes & 0 & .3 & .3 & .6 \\
\hline Bathing in same pond & Yes & 0 & .6 & .3 & .2 \\
\hline Playing together & Yes & 0 & 0 & .4 & .3 \\
\hline Kissing/hugging & Yes & 9.1 & .6 & .8 & .3 \\
\hline Shaking hands & Yes & 4.5 & .0 & 0 & 0 \\
\hline Insect bites & Yes & 4.5 & .6 & .1 & .0 \\
\hline Tears/sweat/saliva & Yes & 0 & 0 & .1 & .2 \\
\hline $\mathbf{N}$ & & 22 & 328 & 898 & 637 \\
\hline
\end{tabular}

* Multiple responses.

Table 4.5 shows adolescents' responses to questions about HIV/AIDS and STDs and routes of transmission. It is clear that while knowledge about HIV/AIDS is high among adolescents, particularly younger adolescents, other sexually transmitted diseases are less known. The majority of the adolescents (>90\%), regardless of sex and marital status, correctly identified mechanisms of disease transmission, such as unprotected intercourse, multiple partners, blood transfusion of HIV patient, and use of unsterilized syringe of HIV patient. Some issues, like kissing or hugging, tears, sweat or saliva, insect bites, sneezing or coughing, sleeping in the same bed, eating with shared utensils, wearing the same clothes, created ambiguity. 
Table 4.6 shows levels of knowledge of family planning methods. In general, knowledge about specific methods of birth control were high, with the highest levels of knowledge reported for the most commonly available and used methods in the country (NIPORT, Mitra and Associates, and ICF International 2013). The pill and condoms were spontaneously mentioned by the majority of boys and girls.

Table 4.6: Adolescents' knowledge of family planning methods, by sex and marital status

\begin{tabular}{|l|l|l|l|l|}
\hline $\mathrm{N}=\mathbf{1 , 6 2 4}$ & \multicolumn{3}{|l|}{ Sex (\%) } & \multicolumn{2}{l|}{ Marital status (\%) } \\
\hline Methods* & Boys & Girls & Ever married & Never married \\
\hline Pill & 60.1 & 86.8 & 94.2 & 69.4 \\
\hline IUD/Copper T & 2.9 & 9.0 & 15.3 & 3.7 \\
\hline Norplant/Implant & 4.2 & 11.8 & 17.8 & 5.8 \\
\hline $\begin{array}{l}\text { Injection/ } \\
\text { Depo-Provera }\end{array}$ & 19.4 & 40.1 & 49.6 & 25.6 \\
\hline Condom & 75.4 & 65.9 & 72.8 & 69.5 \\
\hline Ligation/Operation & 10.9 & 10.8 & 11.2 & 10.7 \\
\hline Vasectomy/Operation & 7.5 & 5.7 & 8.4 & 6.0 \\
\hline Emergency contraceptive pill & 2.5 & 3.5 & 3.7 & 3.0 \\
\hline Temperature method & .5 & .3 & .3 & .4 \\
\hline Safe period & 1.5 & 5.8 & 11.0 & 1.9 \\
\hline Withdrawal & 1.7 & 3.2 & 6.4 & 1.4 \\
\hline $\mathrm{N}$ & 732 & 892 & 353 & 1.271 \\
\hline
\end{tabular}

*Multiple responses.

Table 4.7: Adolescents' ever use of contraception methods by sex and marital status

\begin{tabular}{|l|l|l|l|l|}
\hline \multirow{2}{*}{ Method* } & \multicolumn{3}{|l|}{ Boys (\%) } & Girls (\%) \\
\cline { 2 - 5 } & Ever married & Never married & Ever married & Never married \\
\hline Pill & 27.3 & 0.4 & 61.6 & 1.2 \\
\hline IUD/Copper T & 0.0 & 0.0 & 0.0 & 0.0 \\
\hline Norplant/Implant & .0 & 0.0 & 1.8 & 0.0 \\
\hline Injection/Depo-Provera & 4.5 & 0.0 & 12.4 & .2 \\
\hline Condom & 77.3 & 1.4 & 37.2 & 0.5 \\
\hline Ligation/Operation & 0.0 & 0.0 & 0.6 & 0.2 \\
\hline Vasectomy/Operation & .0 & 0.0 & 0.3 & 0.0 \\
\hline Emergency contraceptive pill & .0 & 0.0 & 1.2 & .0 \\
\hline Temperature method & .0 & 0.0 & 0.6 & .0 \\
\hline Safe period & 18.2 & 0.0 & 16.0 & .0 \\
\hline Withdrawal & 4.5 & 0.0 & 7.3 & .0 \\
\hline $\mathbf{N}$ & 22 & 710 & 331 & 561 \\
\hline
\end{tabular}

*Multiple responses.

Around $61 \%$ of the married adolescent girls have ever used the pill, while $77 \%$ of married adolescent boys have ever used condoms (Table 4.7). Relative to that, use of other methods was low. A considerable number of married adolescents have practiced safe period (18.2\% among married boys and 16\% among married girls), withdrawal or azol (4.5\% and $7.3 \%$ among married boys and married girls, respectively), and injection/Depo-Provera (4.5\% among boys and $12.4 \%$ among married girls) as a family planning method. 
There is relatively little use reported by unmarried boys and girls. Regardless of marital status, girls were more likely to say they discuss SRHR problems with parents, and medical and quack doctors when needed. However, both married and unmarried boys mentioned they discussed SRHR problems with friends (data not shown).

Table 4.8: Adolescents' age at sexual debut by sex

\begin{tabular}{|l|l|l|l|l|}
\hline \multirow{2}{*}{$\begin{array}{l}\text { Age at first sexual } \\
\text { intercourse }\end{array}$} & Age in years & Boys (\%) & Girls (\%) & All (\%) \\
\cline { 2 - 6 } & $<15$ & 4.6 & 10.4 & 7.5 \\
\cline { 2 - 6 } & $15-19$ & $3.6 \%$ & 24.1 & 14.6 \\
\cline { 2 - 6 } & $\begin{array}{l}\text { Did not have } \\
\text { sex }\end{array}$ & 91.6 & 64.8 & 77.6 \\
\hline N & & 971 & 1,058 & 2,029 \\
\hline
\end{tabular}

Table 4.8 shows age at first intercourse. Adolescent girls are considerably more likely than adolescent boys to be sexually active. Sexual activity is related to age at marriage, which is much earlier for girls than boys-$4.6 \%$ of boys and $10.4 \%$ of girls experienced first sex before 15 years of age, and $24.1 \%$ of girls and $3.6 \%$ of boys experienced first sex between 15 and 19 years of age. In the survey the majority of the boys (91\%) did not have any sexual experience compared to $65 \%$ of girls.

\section{MARRIAGE AND CHILDBEARING}

Marriage is a norm that is almost non-negotiable in Bangladeshi society for both men and women, but especially for women. With $66 \%$ of girls getting married before the age of 18 (UNDP 2014), early marriage is very common and is associated with discontinuation of education as well as health consequences. Arranged marriages are common and combined with problems of providing legal consent at marriage as a child; the question of marriage during adolescence has profound implications with the issue of personal freedom to choose, to live a healthy sexual and reproductive life, and the ability to pursue aspirations of education and work.

Among the respondents, the percentage of married boys is considerably lower than the percentage of married girls. Overall, $11 \%$ of respondents are married-19.9 \% of girls compared to $1.2 \%$ of boys. Among adolescent girls who are married, about $50 \%$ have been pregnant and $38 \%$ have one or more children. Even though the legal age at marriage is 18 , the majority of marriages were reported to be registered. A recent study in rural Bangladesh that showed similarly high levels of registration suggests that registration of underage marriage is made possible because of the widespread prevalence of false age certificates and misreporting of age at marriage at the time of registration. 
Table 4.9: Marriage, childbearing, and marriage characteristics by sex

\begin{tabular}{|c|c|c|c|}
\hline Categories and responses & $\begin{array}{r}\text { Girls } \\
(\%)\end{array}$ & $\begin{array}{r}\text { Boys } \\
(\%)\end{array}$ & $\begin{array}{r}\text { All adolescents } \\
(\%)\end{array}$ \\
\hline Marital status of adolescents & $\mathrm{N}=1,803$ & $\mathrm{~N}=1,782$ & $\mathrm{~N}=3,585$ \\
\hline Presently married & 19.9 & 1.2 & 10.6 \\
\hline Separated, abandoned, divorced, widowed & 0.9 & 0.2 & 0.5 \\
\hline Unmarried & 79.3 & 98.7 & 88.9 \\
\hline Pregnancy and childbearing (ever married) & 375 & & \\
\hline Ever pregnant & 50.4 & & \\
\hline Have one or more child & 38.0 & & \\
\hline Demand for dowry & $\mathrm{N}=371$ & 17 & \\
\hline Yes, dowry and other demands & 7.5 & 0.0 & \\
\hline Yes, dowry only & 12.9 & 11.1 & \\
\hline Other demand only & 4.6 & 0.0 & \\
\hline No dowry or other demands & 74.9 & 88.9 & \\
\hline Registration of marriage & $N=310$ & $\mathrm{~N}=17$ & $\mathrm{~N}=327$ \\
\hline Yes & 94.5 & 88.2 & 94.2 \\
\hline No & 4.8 & 5.9 & 4.9 \\
\hline Do not know & 0.6 & 5.9 & 0.9 \\
\hline Most important reason for marriage & $\mathrm{N}=374$ & $\mathrm{~N}=23$ & $\mathrm{~N}=397$ \\
\hline Parents said the proposal is too good to refuse & 66.3 & 60.9 & 66.0 \\
\hline No prospect of continuing school & 1.3 & 0.0 & 1.3 \\
\hline Parents felt pressured & 2.1 & 0.0 & 2.0 \\
\hline Parents afraid about sexual security & 4.0 & 4.3 & 4.0 \\
\hline Own choice & 24.6 & 26.1 & 24.7 \\
\hline Others & 1.6 & 0.0 & 2.0 \\
\hline
\end{tabular}

The most common reason given for why the marriage took place ( $66 \%$ of all adolescents) was that parents thought the proposal was too good to refuse, reported by $60.9 \%$ of boys and $66.3 \%$ of girls. Nevertheless, a good percentage of both boys (26.1\%) and girls $(24.6 \%)$ married according to their own choices. Consent is a crucial issue for marriage, especially for underaged adolescents, and it can indicate forcible or imposed decisions. $85.4 \%$ of adolescents said that they were asked for their opinions and consent to the proposed marriage, higher for boys (95.7\%) than girls (84.8\%) (data not shown).

The proportion of marriages reported to involve a dowry-the demand of money or things by the groom or his family-was surprisingly low. About $25 \%$ of married adolescent girls and $11 \%$ of boys said their marriage entailed some form of dowry. The legal context of dowry, and the emphasis on its illegality in campaigns to change marriage practices, may be a factor leading to the underreporting of dowry exchange.

Table 4.13 shows attitudes and ideals about marriage and related practices, by the sex of the respondent. The majority agree to the age range of 19-24 as the "appropriate age" for a girl to get married (53.6\%), with "20 years" identified by most (32.5\%) as an appropriate age for girls. On the other hand, the appropriate age for boys was indicated as the age bracket of $22-27$ years $(57.3 \%)$, though $30.3 \%$ of adolescents pointed to 25 years as the most appropriate age for boys. This indicates that the common cultural norm of age difference between husband and wife still persists. In order to understand this issue of eligibility, especially for girls, we asked respondents to cite the reason for appropriateness of this age for girls. General opinion is on the "physical preparedness" or readiness of girls-in case of marriage. "Mental preparedness" and ability to "Run a family" are also considered prime reasons for a girl to be married at and/or within a certain age. AN interesting point to be noted here is that the legal age of marriage is not considered as much an issue. 
Related to this is that $82 \%$ of boys think they can say "No" to parents' decision of marriage for them; $68 \%$ of girls said that they can say "No" to a similar situation.

Divorce is still a socially discouraged and often unaccepted practice in Bangladeshi society. $76.2 \%$ of adolescents agreed that women should have the right to divorce. $71.3 \%$ of boys and $81 \%$ of girls agreed on that. This is a very positive indication that, at least in urban areas, messages on women's rights are having some impact.

Table 4.13: Attitudes and ideals about marriage and divorce by sex

\begin{tabular}{|l|r|r|r|}
\hline Categories and responses & $\begin{array}{r}\text { Girls } \\
\text { (\%) }\end{array}$ & $\begin{array}{r}\text { Boys } \\
\text { (\%) }\end{array}$ & $\begin{array}{r}\text { All adolescents } \\
\text { (\%) }\end{array}$ \\
\hline Women should have right to divorce & $\mathrm{N}=1,774$ & \\
\hline Agree & 81.0 & $\mathrm{~N}=3,523$ \\
\hline Disagree & 19.0 & & 76.2 \\
\hline Appropriate age at marriage for boys & $\mathrm{N}=1,774$ & $\mathrm{~N}=1,750$ & 23.8 \\
\hline $15-20$ & 7.5 & 10.1 & $\mathrm{~N}=3,524$ \\
\hline 21 & 19.8 & 15.5 & 8.8 \\
\hline $22-27$ & 56.0 & 58.7 & 17.6 \\
\hline $28+$ & 17 & 15.6 & 57.3 \\
\hline Appropriate age of marriage for girls & $\mathrm{N}=1,774$ & $\mathrm{~N}=1,750$ & 16.1 \\
\hline $12-17$ & 2.0 & 3.8 & $\mathrm{~N}=3,524$ \\
\hline 18 & 35.7 & 35.2 & 2.9 \\
\hline $19-24$ & 53.3 & 53.8 & 35.4 \\
\hline $25+$ & 9.2 & 7.1 & 53.6 \\
\hline
\end{tabular}

\section{SUMMARY AND CONCLUSION}

Adolescent boys and girls revealed poor knowledge about sexual and reproductive health. Half of all girls reported that they did not know about menstruation before they had their first period. In terms of characterizing the experience of puberty, girls were more likely to mention physical or emotional changes, while boys were more likely to identify changes in sexuality. Knowledge about menstrual regulation, a procedure commonly used in Bangladesh to end pregnancies, was correctly identified as to its purpose by the majority of married girls but not by unmarried girls and boys. Knowledge about sexually transmitted diseases other than HIV/AIDS is limited, but adolescents-particularly unmarried adolescents who are more likely to be in school-revealed accurate knowledge about HIV/AIDS. These results are likely attributable to the success of campaigns to raise knowledge about the disease. Given the low prevalence of the disease relative to other STDs, these results suggest a potential area in which greater investments may be made in raising knowledge and information on services and diseases for which adolescents may be at greater risk. Child marriage is surprisingly high, with rates comparable to those estimated for high-child-marriage rural areas. Most adolescent girls who are married are exposed to the risk of childbearing despite relatively high use of contraception, suggesting that contraceptive use is ineffective. 


\title{
Chapter 5 \\ Mobility, Violence, Social Interactions, and Gender Norms
}

\author{
SHUCHI KARIM AND MUHAMMED MAMUNUR RASHID
}

This chapter provides an overview of urban adolescents' practices regarding freedom to move around on their own outside the home, experience of violence, interactions with friends, and values and attitudes regarding gender equity. One objective of exploring these practices is to assess the extent to which social norms differentially influence the lives of girls and boys. We also want to assess the extent of social inclusion in terms of values and attitudes, and notions of entitlement of rights and responsibilities from a gender perspective.

Sexual violence and abuse occurs in many different forms and may happen at home, in school, at work, in the community, or even in cyberspace. Although boys are also affected, past studies show that the majority of the victims of sexual abuse are girls. Girls experience higher rates of domestic and sexual violence than boys; these abuses reinforce male dominance in the household and community and concurrently impede female empowerment (UNICEF 2011).

\section{MOBILITY}

In Bangladeshi society, mobility is influenced by gender, class, and age. Gender norms and gender-specific regulations restrict girls' mobility outside their homes or limit them to specific spaces. Concerns for the safety for girls and religious practices can result in additional normative practices that limit girls' access to public spaces and the right to participate in various activities, such as working in sectors that are predominantly male, playing sports that are thought to be masculine, watching movies that are inappropriately sexual or "Western," or simply being present in spaces that are dominated by men, such as markets or sports events. Concerns about security and safety affect both sexes. While boys are more likely to encounter conflict in public places getting involved in gangs or partisan politics, girls are more likely to be restricted because of concerns about sexual safety. Mobility of adolescents, especially that of girls, is predictably limited. Table 5.1 shows that $36.7 \%$ of adolescents can go out of the home after sunset. 55.5\% of adolescent boys said that they are allowed to go out on their own after sunset; whereas only $18 \%$ of girls are allowed a similar level of freedom regarding mobility, and $26.3 \%$ of girls have conditional and controlled mobility if they are escorted by someone. 
Table 5.1: Physical mobility and related attitudes by sex

\begin{tabular}{|l|l|l|l|}
\hline Categories and responses & Girls (\%) & Boys (\%) & All adolescents (\%) \\
\hline Allowed to go outside after sunset & $\mathrm{N}=1,721$ & $\mathrm{~N}=1,718$ & $\mathrm{~N}=3,439$ \\
\hline Yes & 18.0 & 55.5 & 36.7 \\
\hline No & 55.8 & 31.8 & 43.8 \\
\hline Only if escorted & 26.3 & 12.7 & 19.5 \\
\hline Female should use purdah when going out & $\mathrm{N}=1,793$ & $\mathrm{~N}=1,767$ & $\mathrm{~N}=3,560$ \\
\hline Yes & 93.0 & 92.4 & 92.7 \\
\hline No & 7.0 & 7.6 & 7.3 \\
\hline Type of purdah ideally used & $\mathrm{N}=1,672$ & $\mathrm{~N}=1,642$ & $\mathrm{~N}=3,314$ \\
\hline Burkha & & & \\
\hline Head to be covered by scarf/dupatta & 72.8 & 87.4 & 80.1 \\
\hline Nikab & 20.8 & 10.1 & 15.5 \\
\hline Mental purdah is enough & .5 & .6 & .5 \\
\hline Age to start purdah & 5.9 & 1.9 & 3.9 \\
\hline 11 or less & $\mathrm{N}=1,669$ & $\mathrm{~N}=1,641$ & $\mathrm{~N}=3,310$ \\
\hline 12 & 45.7 & 36.8 & 41.2 \\
\hline $13-17$ & 34.0 & 32.4 & 33.2 \\
\hline $18+$ & 16.7 & 24.0 & 20.3 \\
\hline Do not know & 1.5 & 1.8 & 1.4 \\
\hline & 2.3 & 5.3 & 3.8 \\
\hline
\end{tabular}

Control on mobility is associated with and may be expressed in norms of dress, especially through the practice of purdah. Use of purdah for women outside the home is supported by almost everyone (92.7\%). Interestingly there is not much variation by adolescents' level of education. The nikab is a relatively recent import from the Middle East that covers the body, head, and face in a veil. The burkha is an additional layer of clothing, worn to observe purdah, and usually takes the form of a full length jacket and headscarf that covers the body and hair but not the face. Women may also observe purdah by draping a scarf loosely over their hair but not necessarily covering the entire head. Burkha (hair and body covered, but not face) is considered the proper form of purdah for girls by the majority. $80.1 \%$ of adolescents said that they view burkha as the ideal type of purdah. Boys (87.4\%) more than girls $(72.8 \%)$ consider burkha as proper purdah for girls. More significant regarding purdah issues is respondents' opinion as to the correct/proper age for starting the practice. $41.2 \%$ believe in the age bracket of $1-11$ years and $33.2 \%$ believe it should be age 12. Thus almost three out of four adolescents believe that a girl should start purdah before the age of 13 . About $95 \%$ of adolescents (both boys and girls) said that the main reasons for using purdah are security and social reasons.

\section{SEXUAL HARASSMENT AND VIOLENCE}

A study conducted by the Population Council and icddr,b revealed that about 38 percent of unmarried females and 52 percent of unmarried males (aged 10-24 years) have experienced any physical violence in the past year. Rape, forced prostitution, sexual violence at home and in the workplace are common, but it is difficult to get accurate data on such violence (National Plan of Action 2013). Another large-scale survey representing urban slum and nonslum populations shows that violence against women and girls is significantly higher in slum areas compared with nonslum areas (Camellia, Khan, and Naved 2012). Camellia, Khan, and Naved (2012) find that unmarried adolescent girls in Dhaka slums experience multiple forms of violence-at home, girls were most commonly exposed to emotional violence and controlling behavior; in the community, sexual harassment, extortion, and unfair arbitration; in relationships, girls were 
emotionally abused, forced or coerced into sex, and abandoned. Findings from 22 consultation sessions with adolescent girls and boys in urban Dhaka illustrated that almost all girls, irrespective of economic classes and type of educational institutions, feel they are vulnerable to eve teasing, and to sexual abuse and rape at home, in the community, and at school.

Sexual harassment is a burning issue in Bangladesh when it comes to gender equality and rights for girls. Sexual violence against girls in Bangladesh is high, but in this study responses reflect otherwise. For example, harassment from close relatives has a very low percentage. $96.1 \%$ of all adolescent respondents responded negatively regarding this question $(98.1 \%$ boys and $94.1 \%$ girls said they never experienced "teasing" as a form of harassment). This, on a surface level, should be good news for us, but skepticism is difficult to avoid as it might indicate that "teasing" is not considered harassment because it can be socially sanctioned, and/or adolescents have already learned the dominant norm of hiding/denying experiences of gender-based violence/harassment to protect themselves from social trauma and victimhood. Similar experiences in school or educational spaces got similar negative responses (not experiencing "teasing" in school: boys $96.5 \%$, girls $97.5 \%)$.

Table 5.2: Sexual harassment and violence

\begin{tabular}{|l|l|l|l|}
\hline Categories and responses & $\begin{array}{l}\text { Girls } \\
(\%)\end{array}$ & $\begin{array}{l}\text { Boys } \\
(\%)\end{array}$ & $\begin{array}{l}\text { All adolescents } \\
(\%)\end{array}$ \\
\hline $\begin{array}{l}\text { Have faced teasing, etc., from any close } \\
\text { relative }\end{array}$ & $\mathrm{N}=1,800$ & $\mathrm{~N}=1,768$ & $\mathrm{~N}=3,568$ \\
\hline Yes & 5.9 & 1.9 & 3.9 \\
\hline No & 94.1 & 98.1 & 96.1 \\
\hline Have faced teasing, etc., outside home & $\mathrm{N}=1,799$ & $\mathrm{~N}=1,762$ & $\mathrm{~N}=3,568$ \\
\hline Yes & 28.2 & 5.6 & 17.0 \\
\hline No & 71.8 & 94.4 & 83.0 \\
\hline Have faced teasing, etc., in school/college & $\mathrm{N}=1,698$ & $\mathrm{~N}=1,707$ & $\mathrm{~N}=3,405$ \\
\hline Yes & 4.5 & 2.5 & 3.5 \\
\hline No & 95.5 & 97.5 & 96.5 \\
\hline
\end{tabular}


Table 5.3: Attitudes about disability and religious tolerance

\begin{tabular}{|c|c|c|c|}
\hline Categories and responses & \begin{tabular}{|l|} 
Girls \\
(\%)
\end{tabular} & \begin{tabular}{|l} 
Boys \\
(\%)
\end{tabular} & $\begin{array}{l}\text { All adolescents } \\
\text { (\%) }\end{array}$ \\
\hline Have disabled friend/classmate & $\mathrm{N}=1,784$ & $\mathrm{~N}=1,763$ & $\mathrm{~N}=3,547$ \\
\hline Yes & 8.2 & 15.7 & 11.9 \\
\hline No & 91.8 & 84.3 & 88.1 \\
\hline $\begin{array}{l}\text { How should we behave toward disabled } \\
\text { adolescents }\end{array}$ & $N=1,772$ & $N=1,758$ & $N=3,530$ \\
\hline $\begin{array}{l}\text { Should behave with them as we do with } \\
\text { anyone }\end{array}$ & 78.8 & 84.6 & 81.7 \\
\hline They are a burden & 5.4 & 4.7 & 5.0 \\
\hline $\begin{array}{l}\text { Special and different care and policies } \\
\text { needed for them }\end{array}$ & 1.9 & 2.8 & 2.4 \\
\hline I am not bothered & 12.5 & 6.3 & 9.4 \\
\hline Others & 1.5 & 1.5 & 1.5 \\
\hline $\begin{array}{l}\text { Have friend/s of other } \\
\text { religion/race/community }\end{array}$ & $N=3,551$ & $N=1,765$ & $N=1,786$ \\
\hline Yes & 42.0 & 55.2 & 48.6 \\
\hline No & 58.0 & 44.8 & 51.4 \\
\hline Support marriage across religion & $N=1,469$ & $N=174$ & $N=3,574$ \\
\hline Yes & 18.4 & 20.7 & 19.5 \\
\hline No & 81.6 & 79.3 & 80.5 \\
\hline
\end{tabular}

Table 5.3 shows results from questions about attitudes that reflect attitudes of tolerance toward disabled persons or those of other religious groups. One important element of social justice is social inclusion that is based on identity, be it gender, ethnicity, religion, or disability. Bangladesh being fairly homogenous in terms of language, ethnicity, and with a predominantly Muslim population, these indicators of acceptance may serve as a measure of social inclusion. For example, on the issue of disability, about $12 \%$ of adolescents have a friend or classmate with a disability. A higher percentage of boys (15.7\%) than girls $(8.2 \%)$ have a friend/classmate with a disability. Attitudes and compassion toward friends with different abilities also had positive responses: $81.7 \%$ of adolescents believe that they should behave with the disabled as they do with others. About $10 \%$ said that they were not bothered (i.e., they were indifferent). In case of behaving positively toward the person with a disability, girls are less sensitive than boys ( $84.6 \%$ of boys versus $78.8 \%$ of girls).

About half (48.6\%) of the adolescents have friends of other religions. $55.2 \%$ of boys and $42 \%$ of girls have friends who practice other religions, but they do not support marriage among different religions. Only about $20 \%$ support this. This is similar for both boys and girls.

\section{GENDER EQUITY IN NORMS AND ATTITUDES}

The survey includes a set of questions to assess respondents' attitudes with regard to gender equity. More than four out of five respondents hold the opinion that education is equally important for boys and girls. Just about $5 \%$ of girls thought that boys' education is more important and about the same percentage of boys thought that girls' education is more important (Table 5.4). Boys are much more likely than girls to say that it is acceptable to impose restrictions on activities because of gender. However, responses suggest that both 
boys and girls believe that men and women should follow different scripts with regard to their roles in conjugal/domestic life. Women are considered the primary caregiver and responsible for cooking for the family-the gender stereotyped role for girls/women in households (cooking, caregiving) is supported by $57.2 \%$. But, notably, boys in higher percentages $(62.2 \%)$ agree to these gender roles compared with girls (52.3\%).

Table 5.4: Gender equality norms and attitudes

\begin{tabular}{|c|c|c|c|}
\hline Categories and responses & $\begin{array}{r}\text { Girls } \\
(\%)\end{array}$ & $\begin{array}{r}\text { Boys } \\
(\%)\end{array}$ & $\begin{array}{r}\text { All adolescents } \\
(\%)\end{array}$ \\
\hline $\begin{array}{l}\text { Education is more necessary for boys or } \\
\text { girls }\end{array}$ & $\mathrm{N}=1,776$ & $\mathrm{~N}=1,765$ & $\mathrm{~N}=3,541$ \\
\hline Boys & 4.4 & 13.0 & 8.7 \\
\hline Girls & 12.1 & 5.2 & 8.6 \\
\hline Both & 82.7 & 81.1 & 81.9 \\
\hline Do not know & .8 & .7 & .8 \\
\hline $\begin{array}{l}\text { Activities should be restricted because of } \\
\text { gender }\end{array}$ & $\mathrm{N}=1,801$ & $\mathrm{~N}=1,775$ & $N=3,576$ \\
\hline Yes & 21.7 & 4.1 & 12.9 \\
\hline No & 78.3 & 95.9 & 87.1 \\
\hline $\begin{array}{l}\text { Women are to take care of and cook for the } \\
\text { family }\end{array}$ & $N=1,769$ & $\mathrm{~N}=1,774$ & $N=3,573$ \\
\hline Strongly agree & 8.6 & 13.1 & 10.9 \\
\hline Agree & 52.3 & 62.2 & 57.2 \\
\hline Disagree & 35.9 & 22.8 & 29.4 \\
\hline Strongly disagree & 3.2 & 1.8 & 2.5 \\
\hline Women are to be beaten sometimes & $N=1,798$ & $\mathrm{~N}=1,775$ & $N=3,573$ \\
\hline Agree & 26.0 & 38.6 & 32.3 \\
\hline Disagree & 74.0 & 61.4 & 67.7 \\
\hline $\begin{array}{l}\text { Men should defend their reputation with } \\
\text { force if/when insulted }\end{array}$ & $N=1,798$ & $\mathrm{~N}=1,773$ & $N=3,565$ \\
\hline Agree & 24.4 & 32.0 & 28.2 \\
\hline Disagree & 75.6 & 68.0 & 71.8 \\
\hline A woman should always obey her husband & $N=1,786$ & $N=1,767$ & $N=3,553$ \\
\hline Agree & 87.6 & 95.6 & 91.6 \\
\hline Disagree & 12.4 & 4.4 & 8.4 \\
\hline Men should have final say in all matters & $\mathrm{N}=1,788$ & $\mathrm{~N}=1,772$ & $N=3,560$ \\
\hline Agree & 36.4 & 56.7 & 46.4 \\
\hline Disagree & 63.6 & 43.3 & 53.6 \\
\hline $\begin{array}{l}\text { A woman cannot refuse to have sex with her } \\
\text { husband }\end{array}$ & $N=1,012$ & $N=881$ & $N=2,076$ \\
\hline Agree & 28.8 & 30.6 & 29.6 \\
\hline Disagree & 71.2 & 69.4 & 70.4 \\
\hline
\end{tabular}


Girls are also less likely than boys to accept violence against women. $67.7 \%$ of all adolescents disagree it is justified for men to be violent against women. $61.4 \%$ of boys disagree with that, while $74 \%$ of girls disagree. Violence against women is a practice that is accepted and tolerated by a significant number of women. The majority of boys and girls did not think that boys and men need to resort to aggressive/violent behavior to assert their masculinity, however boys (32\%) were more likely than girls (24\%) to agree that such aggression is desirable.

In contrast, a general question about equality of rights elicited responses that suggest boys and girls value gender equality in the treatment of men and women. 95\% of all respondents agreed with the statement that "Males and females should be treated as same," with more boys "strongly" agreeing than girls. While at $96 \%$, the total of girls' agreement (at varying degrees) is higher than that of boys (94\%) (data not shown).

Gender inequality and norms within marriage were assessed with a question on whether women should obey their husbands. About $91 \%$ of adolescents agreed that a woman should always obey her husband. Boys (95\%) were more likely than girls $(87 \%)$ to support that obedience was valued by women. Interestingly, this does not get reflected in a question on who should make decisions in the household. Less than half (46\%) of respondents agreed that men should dominate decision-making regarding family matters. Boys (57\%) were more likely than girls (36\%) to say that men should have final say in all matters. This could be because of girls conceptually agreeing to male (husband) dominance in marriage (as a normative institution), but in practice household matters might be negotiated in a more participatory but complex gendered manner.

It seems that conceptually boys and girls hold gender equitable values and believe that boys and girls have the right to be treated equally and have equal rights to education. However, when these are expressed in terms of everyday practice, responses are more gender inequitable. For example, compared to wives' obedience to husband which got major support from everyone, especially from boys, in the matter of wives' right to refuse to have sex almost $70 \%$ opined that a wife can refuse sex. The difference between boys and girls is nominal. This has significant implications on the legal aspects of issues of marital rape, which is denied in the Bangladeshi legal system.

\section{SUMMARY AND CONCLUSION}

A recent rural study among adolescent girls included similar questions and themes. Comparison between the two studies, BALIKA Baseline and BIED Needs Assessment, shows that the gender inequitable norms expressed are similar among girls, for example, while respondents said they believed girls and boys should be treated equally, gender inequitable values are expressed in terms of male dominance in the household, women's right to refuse to have sex with husband, underage marriage registration, marriage by own choice, and early marriage of girls. But there are some differences: tolerance to family violence is more agreed upon by rural girls, also beating by the husband is more accepted in rural settings. Caring for the family as the prime role of women is more acceptable to rural girls, and the right to seek divorce is agreed less by rural girls. Table 5.5 summarizes these comparisons. 
Table 5.5: Comparison of BALIKA and Study for Urban Adolescents Needs Assessment Survey

\begin{tabular}{|c|c|}
\hline BALIKA & $\begin{array}{l}\text { Study for Urban Adolescents } \\
\text { Needs Assessment Survey }\end{array}$ \\
\hline $\begin{array}{l}\text { - } \quad 98 \% \text { of girls agreed that girls and boys } \\
\text { deserved to be treated equally }\end{array}$ & $\begin{array}{l}\text { - } 95 \% \text { of adolescents ( } 96 \% \text { girls and } 94 \% \text { boys) } \\
\text { agreed that males and females should be } \\
\text { treated the same }\end{array}$ \\
\hline $\begin{array}{l}\text { - } 83 \% \text { of married girls and } 75 \% \text { of unmarried } \\
\text { girls reported that taking care of the family } \\
\text { was a woman's primary role }\end{array}$ & $\begin{array}{l}\text { - } 68 \% \text { of adolescents ( } 75 \% \text { boys and } 61 \% \text { girls) } \\
\text { agreed that a woman takes care of and cooks for } \\
\text { the family }\end{array}$ \\
\hline $\begin{array}{l}\text { - } 44 \% \text { of married girls and } 39 \% \text { of unmarried } \\
\text { girls reported that men should have the } \\
\text { final say in all family matters }\end{array}$ & $\begin{array}{l}\text { - } 46 \% \text { of adolescents ( } 57 \% \text { boys and } 36 \% \text { girls) } \\
\text { agreed that men should have final say in all } \\
\text { matters }\end{array}$ \\
\hline $\begin{array}{l}\text { - } 50 \% \text { of married girls reported that a man } \\
\text { who beats his wife is justified under certain } \\
\text { circumstances }\end{array}$ & $\begin{array}{l}32 \% \text { of adolescents ( } 39 \% \text { boys and } 26 \% \text { girls) } \\
\text { agreed that women are to be beaten sometimes }\end{array}$ \\
\hline $\begin{array}{l}\text { - } 58 \% \text { of married girls reported that women } \\
\text { should tolerate violence to "preserve the } \\
\text { harmony of family life" compared to } 47 \% \text { of } \\
\text { unmarried girls }\end{array}$ & $\begin{array}{l}\text { - } 27 \% \text { of adolescents ( } 32 \% \text { boys and } 21 \% \text { girls) } \\
\text { agreed that women should tolerate violence to } \\
\text { keep the family together }\end{array}$ \\
\hline $\begin{array}{l}\text { - } 55 \% \text { of girls overall agreed that women } \\
\text { should have the right to seek divorce }\end{array}$ & $\begin{array}{l}\text { - } 76 \% \text { of adolescents ( } 71 \% \text { boys and } 81 \% \text { girls) } \\
\text { agreed that women should have the right to } \\
\text { divorce }\end{array}$ \\
\hline $\begin{array}{l}\text { - } 38 \% \text { of girls overall agreed that a wife can } \\
\text { refuse to have sex with her husband }\end{array}$ & $\begin{array}{l}\text { - } 30 \% \text { of adolescents ( } 31 \% \text { boys and } 29 \% \text { girls) } \\
\text { agreed that a woman cannot refuse to have sex } \\
\text { with her husband }\end{array}$ \\
\hline $\begin{array}{l}\text { - Over } 90 \% \text { of underage marriages are } \\
\text { registered by obtaining false birth } \\
\text { certificates }\end{array}$ & $\begin{array}{l}\text { - } 100 \% \text { of underage boys and } 84 \% \text { of underage } \\
\text { girls have marriage registration }\end{array}$ \\
\hline \multirow{2}{*}{$\begin{array}{l}\text { - "Own choice" or "love marriages" are on the } \\
\text { rise: } 23 \% \text { of marriages are characterized as } \\
\text { love marriages and are more common } \\
\text { among girls with more education. They are } \\
\text { also less likely to involve a dowry. }\end{array}$} & $\begin{array}{l}\text { - } 24 \% \text { of adolescents (boys } 35 \% \text { and girls } 23 \% \text { ) } \\
\text { married by choosing each other. }\end{array}$ \\
\hline & $\begin{array}{l}63 \% \text { of adolescents (boys } 57 \% \text { and girls } 64 \% \text { ) } \\
\text { married through family arrangement }\end{array}$ \\
\hline
\end{tabular}




\section{Chapter 6 Mental Health}

\section{JYOTIRMOY SAHA AND SHAKILA YESMIN}

Comprehensive mental health assessments in surveys among adolescent populations are rare in Bangladesh. In an attempt to explore the prevalence of depression, Nasreen, Kabir, and Edhborg (2013) concluded that depressive symptoms were found to occur commonly among adolescents in Bangladesh, with predominance in urban slums and among girls. Reproductive illness and sexual abuse were found to be associated with depressive symptoms for girls. More than $80 \%$ of depressed adolescents sought no help, meaning that there is a need for specific services such as community-based counseling.

We reviewed global research on adolescent mental health taking into account the nature of assessments and focused on studies in comparable populations and comparable indicators. For school-going adolescents, topics that have been associated with mental health are bullying, examination systems, and academic performance. A study in the city of Kolkata in India examined academic stress and mental health. About twothirds of the students $(66 \%)$ reported that parental pressure for good academic performance is the primary reason for academic stress (Deb, Strodi, and Sun 2015). The study found an association with economic status-parents with lower educational levels and economic status were found to put more pressure on their children, compared with parents with graduation and post-graduation background and those of higher economic status (Deb, Strodi, and Sun 2015).

A qualitative study on teenage mental health in Ireland identified academic systems of test-taking as a major source of stress. The study sought to explore ways of alleviating mental distress among teens by conducting focus group interviews. Teenagers reported examination systems, particularly national school leaving examinations, as a major source of stress (Ministry of Health and Children Affairs 2009). A study exploring the correlation between the academic performance of 83 school-going adolescents at risk for major depression suggests that the participants suffering from depressive symptoms reported feeling sad, which affected their academic performance at school, concentration level in the classroom, attendance level, and completion of assignments (Humemsky et al. 2010). Two studies on bullying, in Finland and New South Wales, Australia, showed an association of psychosocial health and bullying-both those who are bullied and those who bully others were more likely to report poor health (Forero et al. 1999; Kaltiala-Heino et al. 1999).The Finnish study used a 13-point Beck scale and also found an association with juvenile delinquency, alcohol misuse, and violence and criminal behaviors in adulthood.

Other factors associated with mental health are sex, marriage, economic status, and experience of intimate partner violence. Studies that explored mental health by economic status found depression to be more common among women who live in poverty (Kumar, Nehra, and Dahiya 2013). A comprehensive metaanalysis revealed that abused women had a three to five times greater chance than the general population of experiencing depression: suicidal tendencies, PTSD, alcohol abuse, and drug abuse (Rose et al 2010). Women who are married as children are more likely than women who are married as adults to report mental health problems (Singh and Samarah 1996).

\section{MENTAL HEALTH ASSESSMENT}

In this survey, we used the Beck Depression Inventory (BDI-II) to assess depressive symptoms (Beck et al. 1996), and the total scores on the BDI-II ranged from 0 to 63 . The BDI-II was specifically constructed to measure the severity of self-reported depression in adolescents and adults. Although the BDI-II is typically a self-report measure, providers can also verbally administer the measure to adolescents. It contains 21 questions with a scale value of 0 to 3 . All scale scores were derived by summing the items in each scale (item range, 0 to 3 ) and were treated as continuous measures. Adolescents with scores ranging from 0 to 13 
were considered as having a minimal level of depression, from 14 to 19 as mild, from 20 to 28 as moderate, and from 29 to 63 as severe depressive symptoms.

Differences in the depression level of adolescents by socio-demographic characteristics, marital status, harassment at school or outside, bullying, substance abuse, learning outcomes, childhood trauma, treatment at school by teachers, assets in the household, and exposure to media were analyzed using the Chi square $\left(X^{2}\right)$ test. After that, we examined the effects of the above variables on the mental health status of adolescents using multivariate logistic regression models with adjustment socio-demographic characteristics. All statistical analyses were performed using Stata version 13.0. Statistical significance was defined as $p<0.05$.

Table 6.1 reveals the distribution of mental health status of adolescents by their socio-demographic characteristics in Dhaka city corporation. Survey results indicate that there exists significant differences in depression level by age group-16-19-year-olds were significantly more likely to be moderately or severely depressed than 12-15-year-olds. Orphanhood is associated with higher levels of depression. $26.3 \%$ of adolescents who had only fathers in their lives had moderate depression and $13.2 \%$ had severe depression. Other categories of orphans, only mother alive or no parents alive, were not significantly different from adolescents with both parents alive. There was less variation by father's and mother's education.

Table 6.1: Association between mental health status / depression level of adolescents and socio-demographic characteristics

\begin{tabular}{|c|c|c|c|c|c|c|c|}
\hline Variables & $\begin{array}{l}\text { Depression } \\
\text { level }\end{array}$ & $\begin{array}{l}\text { Minimal } \\
\text { (\%) }\end{array}$ & $\begin{array}{l}\text { Mild } \\
\text { (\%) }\end{array}$ & $\begin{array}{l}\text { Moderate } \\
(20-28) \\
(\%) \\
\end{array}$ & $\begin{array}{l}\text { Severe } \\
(29-63) \\
(\%) \\
\end{array}$ & $N$ & $\begin{array}{l}\text { P-value } \\
\text { (chi-square) }\end{array}$ \\
\hline \multirow{2}{*}{ Age } & $12-15$ years & 73.3 & 12.9 & 8.8 & 5.0 & 1,876 & \multirow{2}{*}{0.000} \\
\hline & $16-19$ years & 62.9 & 16.9 & 12.6 & 7.6 & 1,701 & \\
\hline \multirow{4}{*}{ Orphanhood } & $\begin{array}{l}\text { Both father } \\
\text { and mother } \\
\text { alive }\end{array}$ & 68.9 & 14.8 & 10.3 & 6.1 & 3,275 & \multirow{4}{*}{0.019} \\
\hline & $\begin{array}{l}\text { Only father } \\
\text { alive }\end{array}$ & 42.1 & 18.4 & 26.3 & 13.2 & 38 & \\
\hline & $\begin{array}{l}\text { Only mother } \\
\text { alive }\end{array}$ & 65.7 & 14.6 & 13.3 & 6.4 & 233 & \\
\hline & None alive & 69.2 & 15.4 & 7.7 & 7.7 & 13 & \\
\hline \multirow{4}{*}{$\begin{array}{l}\text { Father's } \\
\text { education }\end{array}$} & $\begin{array}{l}\text { Primary } \\
\text { incomplete }\end{array}$ & 65.0 & 15.5 & 13.4 & 6.1 & 1,367 & \multirow{4}{*}{0.000} \\
\hline & $\begin{array}{l}\text { Primary } \\
\text { complete }\end{array}$ & 71.4 & 15.1 & 8.0 & 5.5 & 584 & \\
\hline & $\begin{array}{l}\text { Secondary } \\
\text { incomplete }\end{array}$ & 70.1 & 16.1 & 9.4 & 4.3 & 626 & \\
\hline & $\begin{array}{l}\text { SSC and } \\
\text { above }\end{array}$ & 70.1 & 12.8 & 9.0 & 8.1 & 1,000 & \\
\hline \multirow{4}{*}{$\begin{array}{l}\text { Mother's } \\
\text { education }\end{array}$} & $\begin{array}{l}\text { Primary } \\
\text { incomplete }\end{array}$ & 66.0 & 14.6 & 13.4 & 6.0 & 1,510 & \multirow{4}{*}{0.000} \\
\hline & $\begin{array}{l}\text { Primary } \\
\text { complete }\end{array}$ & 72.1 & 14.8 & 8.6 & 4.5 & 628 & \\
\hline & $\begin{array}{l}\text { Secondary } \\
\text { incomplete }\end{array}$ & 68.8 & 16.5 & 8.8 & 5.9 & 830 & \\
\hline & $\begin{array}{l}\text { SSC and } \\
\text { above }\end{array}$ & 69.8 & 12.8 & 8.2 & 9.2 & 609 & \\
\hline
\end{tabular}




\begin{tabular}{|c|c|c|c|c|c|c|c|}
\hline \multirow{4}{*}{$\begin{array}{l}\text { Self- } \\
\text { education }\end{array}$} & $\begin{array}{l}\text { Primary } \\
\text { incomplete }\end{array}$ & 64.7 & 18 & 10.8 & 6.5 & 743 & \multirow{4}{*}{0.030} \\
\hline & $\begin{array}{l}\text { Primary } \\
\text { complete }\end{array}$ & 64.4 & 15.4 & 12.9 & 7.2 & 402 & \\
\hline & $\begin{array}{l}\text { Secondary } \\
\text { incomplete }\end{array}$ & 71.1 & 12.8 & 10.2 & 5.9 & 1,750 & \\
\hline & $\begin{array}{l}\text { SSC and } \\
\text { above }\end{array}$ & 67.7 & 16 & 10.1 & 6.2 & 682 & \\
\hline \multirow[b]{2}{*}{ Religion } & Muslim & 68.1 & 14.9 & 10.7 & 6.3 & 3,419 & \multirow[b]{2}{*}{0.552} \\
\hline & $\begin{array}{l}\text { Other religion } \\
\text { (Hindu, } \\
\text { Christian, } \\
\text { Buddhist) }\end{array}$ & 73.4 & 13.3 & 8.2 & 5.1 & 158 & \\
\hline \multirow{3}{*}{$\begin{array}{l}\text { Number of } \\
\text { siblings }\end{array}$} & None & 71.9 & 15.1 & 8.1 & 4.9 & 185 & \multirow{3}{*}{0.080} \\
\hline & 1 to 2 & 69.2 & 14.8 & 9.6 & 6.4 & 2,187 & \\
\hline & 3 or more & 66.3 & 14.8 & 12.9 & 6.1 & 1,205 & \\
\hline
\end{tabular}

\begin{tabular}{|c|c|c|c|c|c|c|c|c|}
\hline Variables & \multicolumn{2}{|c|}{ Depression level } & $\begin{array}{l}\text { Minimal } \\
(0-13) \\
(\%)\end{array}$ & $\begin{array}{l}\text { Mild } \\
(14-19) \\
(\%)\end{array}$ & $\begin{array}{l}\text { Moderate } \\
(20-28) \\
(\%)\end{array}$ & $\begin{array}{l}\text { Severe } \\
(29-63) \\
(\%)\end{array}$ & $\mathrm{N}$ & $\begin{array}{l}\text { P-value } \\
\text { (chi- } \\
\text { square) }\end{array}$ \\
\hline \multicolumn{9}{|c|}{ Marital status and pregnancy } \\
\hline \multirow{2}{*}{$\begin{array}{l}\text { Ever been } \\
\text { pregnant }\end{array}$} & \multicolumn{2}{|l|}{ Yes } & 55.0 & 15.3 & 21.7 & 7.9 & 189 & \multirow{2}{*}{0.015} \\
\hline & \multicolumn{2}{|l|}{ No } & 64.5 & 18.6 & 9.8 & 7.1 & 183 & \\
\hline \multirow{2}{*}{$\begin{array}{l}\text { Number of } \\
\text { children alive }\end{array}$} & \multicolumn{2}{|c|}{ At least one child } & 54.2 & 14.8 & 23.2 & 7.7 & 142 & \multirow{2}{*}{0.841} \\
\hline & \multicolumn{2}{|l|}{ None } & 57.4 & 17.0 & 17.0 & 8.5 & 47 & \\
\hline \multirow{4}{*}{$\begin{array}{l}\text { Marital } \\
\text { status }\end{array}$} & \multirow{2}{*}{ Boys } & $\begin{array}{l}\text { Ever } \\
\text { married }\end{array}$ & 56.5 & 17.4 & 13 & 13 & 23 & \multirow{2}{*}{0.612} \\
\hline & & $\begin{array}{l}\text { Never } \\
\text { married }\end{array}$ & 66.6 & 16.6 & 9.9 & 6.9 & 1,754 & \\
\hline & \multirow{2}{*}{ Girls } & $\begin{array}{l}\text { Ever } \\
\text { married }\end{array}$ & 59.8 & 16.9 & 15.8 & 7.5 & 373 & \multirow{2}{*}{0.000} \\
\hline & & $\begin{array}{l}\text { Never } \\
\text { married }\end{array}$ & 73.0 & 11.9 & 10.1 & 5.0 & 1,427 & \\
\hline \multicolumn{9}{|c|}{ Harassment, bullying, and drugs } \\
\hline \multirow{2}{*}{$\begin{array}{l}\text { Harassment } \\
\text { at home }\end{array}$} & \multicolumn{2}{|l|}{ Yes } & 51.1 & 20.9 & 20.1 & 7.9 & 139 & \multirow{2}{*}{0.000} \\
\hline & No & & 69.1 & 14.5 & 10.2 & 6.2 & 3,438 & \\
\hline \multirow{2}{*}{$\begin{array}{l}\text { Harassment } \\
\text { outside }\end{array}$} & \multicolumn{2}{|l|}{ Yes } & 64.4 & 15.5 & 12.9 & 7.3 & 606 & \multirow{2}{*}{0.079} \\
\hline & \multicolumn{2}{|l|}{ No } & 69.2 & 14.6 & 10.1 & 6.0 & 2,971 & \\
\hline \multirow{2}{*}{$\begin{array}{l}\text { Harassment } \\
\text { at school }\end{array}$} & \multirow{2}{*}{\multicolumn{2}{|c|}{$\begin{array}{l}\text { Yes } \\
\text { No }\end{array}$}} & 61.0 & 10.2 & 17.8 & 11.0 & 118 & \multirow{2}{*}{0.003} \\
\hline & & & 68.8 & 15 & 10.2 & 6.0 & 3,326 & \\
\hline Faced any & \multicolumn{2}{|l|}{ Yes } & 65.4 & 13.1 & 11.2 & 10.3 & 107 & \multirow[b]{2}{*}{0.375} \\
\hline $\begin{array}{l}\text { other } \\
\text { students } \\
\text { inside school }\end{array}$ & \multicolumn{2}{|l|}{ No } & 68.3 & 14.8 & 10.7 & 6.2 & 3,358 & \\
\hline \multirow{2}{*}{$\begin{array}{l}\text { Have you } \\
\text { ever taken } \\
\text { drugs or } \\
\text { alcohol }\end{array}$} & \multicolumn{2}{|l|}{ Yes } & 58.3 & 16.5 & 20.5 & 4.7 & 127 & \multirow{2}{*}{0.002} \\
\hline & \multicolumn{2}{|l|}{ No } & 68.8 & 14.7 & 10.2 & 6.3 & 3,450 & \\
\hline
\end{tabular}




\begin{tabular}{|c|c|c|c|c|c|c|c|}
\hline \multicolumn{8}{|l|}{ Learning outcome } \\
\hline \multirow{2}{*}{$\begin{array}{l}\text { Have you ever } \\
\text { repeated a grade in } \\
\text { secondary school }\end{array}$} & Yes & 67.3 & 17 & 10.5 & 5.2 & 306 & \multirow{2}{*}{0.307} \\
\hline & No & 73.0 & 12.7 & 8.4 & 5.9 & 2,057 & \\
\hline \multirow{2}{*}{$\begin{array}{l}\text { Performance on } \\
\text { math }\end{array}$} & $\begin{array}{l}\text { Correctly } \\
\text { answered } 7 \text { or } \\
\text { more out of } 15 \\
\text { math questions }\end{array}$ & 71.9 & 13.7 & 8.8 & 5.6 & 2,591 & \multirow{2}{*}{0.000} \\
\hline & $\begin{array}{l}\text { Correctly } \\
\text { answered less } \\
\text { than } 7 \text { out of } 15 \\
\text { math questions }\end{array}$ & 59.9 & 17.5 & 14.8 & 7.8 & 873 & \\
\hline \multirow{2}{*}{$\begin{array}{l}\text { Performance on } \\
\text { analogy }\end{array}$} & $\begin{array}{l}\text { Correctly } \\
\text { answered all } 4 \\
\text { questions }\end{array}$ & 72.3 & 13.3 & 9.5 & 4.8 & 2,375 & \multirow[b]{2}{*}{0.000} \\
\hline & $\begin{array}{l}\text { Correctly } \\
\text { answered less } \\
\text { than } 4 \\
\text { questions } \\
\end{array}$ & 61.4 & 17.5 & 12.1 & 8.9 & 1,089 & \\
\hline \multicolumn{8}{|l|}{ Childhood trauma } \\
\hline \multirow{2}{*}{$\begin{array}{l}\text { Faced any } \\
\text { emergency or } \\
\text { disaster (man- } \\
\text { made/natural, for } \\
\text { example flood, } \\
\text { collapse) }\end{array}$} & Yes & 53.5 & 15.6 & 12 & 18.9 & 507 & \multirow[b]{2}{*}{0.000} \\
\hline & No & 71.0 & 14.6 & 10.4 & 4.1 & 3,024 & \\
\hline \multicolumn{8}{|l|}{ Asset list } \\
\hline \multirow{2}{*}{ Radio } & Yes & 56.1 & 14.2 & 8.9 & 20.8 & 394 & \multirow{2}{*}{0.000} \\
\hline & No & 69.9 & 14.9 & 10.8 & 4.4 & 3,173 & \\
\hline \multirow{2}{*}{ Television } & Yes & 68.9 & 14.6 & 10.1 & 6.4 & 3,115 & \multirow{2}{*}{0.212} \\
\hline & No & 64.8 & 16.2 & 13.8 & 5.2 & 458 & \\
\hline \multirow{2}{*}{ Sewing machine } & Yes & 72.6 & 11.2 & 7.9 & 8.2 & 680 & \multirow{2}{*}{0.000} \\
\hline & No & 67.3 & 15.7 & 11.3 & 5.8 & 2,880 & \\
\hline \multirow[b]{2}{*}{ Telephone/Mobile } & Yes & 68.7 & 14.6 & 10.7 & 6.1 & 3,445 & \multirow{2}{*}{0.253} \\
\hline & No & 60.7 & 19.7 & 9 & 10.7 & 122 & \\
\hline
\end{tabular}




\begin{tabular}{|c|c|c|c|c|c|c|c|}
\hline \multicolumn{8}{|l|}{ Media exposure } \\
\hline \multirow{2}{*}{$\begin{array}{l}\text { Listened to radio } \\
\text { last week }\end{array}$} & Yes & 66.8 & 12.3 & 11 & 9.9 & 1,008 & \multirow{2}{*}{0.000} \\
\hline & No & 69 & 15.8 & 10.4 & 4.8 & 2,569 & \\
\hline \multirow{2}{*}{$\begin{array}{l}\text { Watched television } \\
\text { last week }\end{array}$} & Yes & 68 & 14.9 & 10.8 & 6.3 & 3,373 & \multirow{2}{*}{0.276} \\
\hline & No & 74 & 13.7 & 7.8 & 4.4 & 204 & \\
\hline \multirow{3}{*}{ Saying prayer } & Daily & 70.7 & 15.9 & 9.1 & 4.3 & 552 & \multirow{3}{*}{0.000} \\
\hline & Sometimes & 67.6 & 14.1 & 10.3 & 8 & 2,218 & \\
\hline & Never & 68.9 & 16 & 12.4 & 2.7 & 807 & \\
\hline \multicolumn{8}{|l|}{ Treatment in school } \\
\hline \multirow{3}{*}{ Last attended school } & Government & 65.9 & 15.1 & 12.8 & 6.1 & 1,262 & \multirow{3}{*}{0.008} \\
\hline & Private and NGO & 70.9 & 14.3 & 8.8 & 6.1 & 2,080 & \\
\hline & Religious & 64.5 & 15.9 & 11.2 & 8.4 & 107 & \\
\hline \multirow{2}{*}{$\begin{array}{l}\text { Teacher teases or } \\
\text { mocks based on } \\
\text { intelligence }\end{array}$} & Yes & 65.2 & 14.5 & 11.5 & 8.8 & 330 & \multirow{2}{*}{0.006} \\
\hline & No & 73.4 & 13.1 & 8.2 & 5.3 & 2019 & \\
\hline \multirow{2}{*}{$\begin{array}{l}\text { Teacher teases or } \\
\text { mocks based on } \\
\text { general cleanliness }\end{array}$} & Yes & 66 & 16.2 & 9.2 & 8.6 & 791 & \multirow{2}{*}{0.000} \\
\hline & No & 75.4 & 11.8 & 8.3 & 4.4 & 1,558 & \\
\hline \multicolumn{8}{|c|}{ Marriage, dowry, and work status } \\
\hline \multirow{2}{*}{ Forced marriage } & Yes & 33.3 & 22.2 & 29.6 & 14.8 & 27 & \multirow{2}{*}{0.026} \\
\hline & No & 61.5 & 16.7 & 14.6 & 7.3 & 371 & \\
\hline \multirow{2}{*}{$\begin{array}{l}\text { Marriage with dowry } \\
\text { and demand }\end{array}$} & Yes & 47.4 & 18.9 & 20 & 13.7 & 95 & \multirow{2}{*}{0.006} \\
\hline & No & 64.2 & 16.4 & 14.3 & 5.1 & 293 & \\
\hline \multirow{2}{*}{ Currently working } & Yes & 51.3 & 16.3 & 18.8 & 13.8 & 80 & \multirow{2}{*}{0.093} \\
\hline & No & 61.6 & 17.3 & 14.8 & 6.3 & 318 & \\
\hline \multirow{2}{*}{ Ever been pregnant } & Yes & 55.2 & 16 & 21.1 & 7.7 & 194 & \multirow{2}{*}{0.001} \\
\hline & No & 64.6 & 18.2 & 9.4 & 7.8 & 192 & \\
\hline
\end{tabular}

Among individual factors associated with depression are marriage, childbearing, experience of harassment, drug use, performance in school, and experience of disasters/conflict during childhood. Adolescent girls who have never been pregnant were shown to experience lesser depression than women who have experienced it. Women who have experienced pregnancy are more likely to report signs of moderate or severe depression. Similarly, adolescents who had at least one child exhibit more signs of moderate or severe depression than those with no children. Never-married girls are less depressed than ever-married adolescent girls. Adolescents who reported experiences of harassment at home or school were found to be significantly more depressed than adolescents who did not report being harassed. Among adolescents who have experienced harassment at home and school, about $28.0 \%$ and $28.8 \%$ respectively, suffer from moderate and severe levels of depression compared with $16.4 \%$ and $16.2 \%$ of those who did not experience harassment, respectively. Mental health status was significantly associated with use of drugs or alcohol. About $69 \%$ of participants who have never taken drugs or alcohol were in the minimal depression level, whereas only $58.3 \%$ of adolescents who have taken drugs or alcohol were found in same category. Respondents who performed well in the math and analogy sections had a significantly lower percentage of depression symptoms compared with others. Respondents who have faced any emergency or disaster (manmade/ natural, for example flood, collapse) were found to be 14.8 percentage points higher in the severe level of depression compared to those who never faced any emergency/disaster.

Since the factors we are considering may be correlated with each other, we explored these associations in multivariate models to predict the likelihood of moderate to severe depression. Table 6.2 shows the odds of being moderately or severely depressed as obtained from a logistic regression model where the outcome is coded as 1 if the response falls in the moderate or severe depression category, and 0 otherwise.

Adolescents who are not orphans (either parent or both dead is the reference category) are less likely to be depressed, as are younger adolescents. Adolescents who report being harassed at home or in school are 
more likely to be depressed, but those who report being harassed in a public place or by their own classmates are not significantly different from those who did not experience such harassment. Two learning assessment indicators showed that those who had higher competence were less likely to be depressed. Adolescents who have children are more likely to be depressed as are adolescents who have experienced disasters. Adolescents who are depressed listen to the radio more often than adolescents who are not depressed, and similarly those who are depressed are more likely to pray.

Table 6.2: Results from logistic regression analysis of covariates of depression, BDI scale

\begin{tabular}{|c|c|c|c|c|c|}
\hline $\begin{array}{l}\text { Mental Health Composite Score }(0 \\
=\text { minimal and mild }(0-29) ; 1= \\
\text { moderate and severe }(30-63)\end{array}$ & $\begin{array}{l}\text { Adjusted } \\
\text { odds } \\
\text { ratio }\end{array}$ & $\begin{array}{l}\text { Standard } \\
\text { error }\end{array}$ & P-value & \multicolumn{2}{|c|}{$95 \%$ confidence interval } \\
\hline $\begin{array}{l}\text { Orphan (ref = either father or } \\
\text { mother not alive or both dead) }\end{array}$ & 0.75 & 0.12 & 0.069 & 0.54 & 1.02 \\
\hline \multicolumn{6}{|l|}{ Total number of siblings } \\
\hline 1 to 2 & 1.40 & 0.34 & 0.166 & 0.87 & 2.27 \\
\hline $3+$ & 1.44 & 0.36 & 0.149 & 0.88 & 2.35 \\
\hline Age (ref = 12-15) & 1.26 & 0.13 & 0.031 & 1.02 & 1.55 \\
\hline Ever taken drugs $($ ref $=$ No) & 1.26 & 0.29 & 0.314 & 0.80 & 2.00 \\
\hline Harassment at home $(r e f=$ no $)$ & 1.65 & 0.37 & 0.025 & 1.07 & 2.56 \\
\hline Harassment outside $(r e f=n o)$ & 1.02 & 0.14 & 0.864 & 0.78 & 1.34 \\
\hline Harassment at school (ref $=$ no) & 1.68 & 0.43 & 0.043 & 1.02 & 2.77 \\
\hline $\begin{array}{l}\text { Teased by own classmate }(\text { ref }= \\
\text { no) }\end{array}$ & 0.79 & 0.23 & 0.409 & 0.45 & 1.39 \\
\hline $\begin{array}{l}\text { Performance on math questions } \\
\text { (ref = answered less than } 7 \\
\text { questions correctly among 15) }\end{array}$ & 0.54 & 0.07 & 0.000 & 0.42 & 0.69 \\
\hline $\begin{array}{l}\text { Performance on analogy section } \\
\text { (ref = answered less than } 4 \\
\text { questions correctly among } 4 \text { ) }\end{array}$ & 0.70 & 0.08 & 0.001 & 0.57 & 0.87 \\
\hline $\begin{array}{l}\text { Faced any emergency or disaster } \\
(\text { ref }=\text { no) }\end{array}$ & 2.49 & 0.29 & 0.000 & 1.98 & 3.14 \\
\hline Listened to radio $(\mathrm{ref}=\mathrm{no})$ & 1.51 & 0.16 & 0.000 & 1.22 & 1.86 \\
\hline Saying prayer $($ ref $=$ never $)$ & 1.29 & 0.16 & 0.044 & 1.01 & 1.66 \\
\hline $\begin{array}{l}\text { Own education (ref = primary } \\
\text { complete) }\end{array}$ & 1.20 & 0.15 & 0.157 & 0.93 & 1.54 \\
\hline Sex (ref = boy) & 1.07 & 0.12 & 0.576 & 0.85 & 1.34 \\
\hline \multicolumn{6}{|l|}{$\begin{array}{l}\text { Marital and childbearing status } \\
\text { (ref = not married) }\end{array}$} \\
\hline Married but no child & 0.93 & 0.19 & 0.703 & 0.62 & 1.38 \\
\hline Married and at least one child & 1.83 & 0.41 & 0.007 & 1.00 & 2.84 \\
\hline $\mathbf{N}$ & 3,318 & & & & \\
\hline Log likelihood & $\begin{array}{l}- \\
1,412.06\end{array}$ & & & & \\
\hline
\end{tabular}

\section{COUNSELING SUPPORT}

Table 6.3 represents the distribution of the adolescents who are willing to talk to counselors by issues they want to discuss, age, sex, marital status, and areas. Adolescents want to discuss different issues such as sexual and reproductive health, relationships, career path, exams, and school stress if a counselor is available. Table 6.3 shows that considering age, sex, marital status, and areas of City Corporation, most of the adolescents talk to counselors about their career path and about exam and school stress. In addition, 
they want to discuss relationships and sexual and reproductive health issues with counselors. Less than 10 percent of adolescents report that they do not know about the service.

Data indicate that there is a need for counseling support/ service among adolescents where they can share their story and get guidance and support while maintaining confidentiality. In reality, many parents are unable to understand adolescents' emotional needs and as a result they do not take appropriate care. So counseling is a kind of service where adolescents can express themselves without fear or hesitation.

Counseling service should be adolescent-friendly and easily accessible.

Table 6.3: Percentage of adolescents willing to talk to counselors, by issues they want to discuss, age, sex, marital status, and area of residence

\begin{tabular}{|c|c|c|c|c|c|c|c|c|c|c|}
\hline \multirow[t]{2}{*}{ Variable } & \multicolumn{2}{|l|}{ Age } & \multicolumn{2}{|l|}{ Sex } & \multicolumn{2}{|c|}{ Marital status } & \multicolumn{4}{|c|}{ City Corporation } \\
\hline & $\begin{array}{l}12-15 \\
\text { years } \\
N=1,850\end{array}$ & $\begin{array}{l}16-19 \\
\text { years } \\
N=1,676\end{array}$ & $\begin{array}{l}\text { Boys } \\
N= \\
1,754\end{array}$ & $\begin{array}{l}\text { Girls } \\
N= \\
1,772\end{array}$ & $\begin{array}{l}\text { Ever } \\
\text { married } \\
\mathrm{N}=390\end{array}$ & $\begin{array}{l}\text { Never } \\
\text { married } \\
\mathrm{N}=3,136\end{array}$ & $\begin{array}{l}\text { Dhaka } \\
\text { North } \\
N= \\
1,176\end{array}$ & $\begin{array}{l}\text { Dhaka } \\
\text { South } \\
N= \\
1,171\end{array}$ & $\begin{array}{l}\text { Gazipur } \\
\mathrm{N}=1179\end{array}$ & $\begin{array}{l}\text { All } \\
\text { areas } \\
\mathrm{N}=3,526\end{array}$ \\
\hline $\begin{array}{l}\text { Sexual and } \\
\text { reproductive } \\
\text { health (\%) }\end{array}$ & 5.7 & 16.5 & 9.4 & 12.4 & 34.1 & 8.0 & 8.9 & 9.5 & 14.2 & 10.9 \\
\hline $\begin{array}{l}\text { Relationship } \\
\text { (\%) }\end{array}$ & 7.2 & 17.2 & 9.1 & 14.7 & 28.7 & 9.9 & 15.6 & 10.6 & 9.7 & 11.9 \\
\hline $\begin{array}{l}\text { Career path } \\
(\%)\end{array}$ & 25.0 & 41.7 & 38.2 & 27.8 & 25.9 & 33.3 & 33.2 & 33.7 & 31.9 & 33.0 \\
\hline $\begin{array}{l}\text { Exam and } \\
\text { school } \\
\text { stress (\%) }\end{array}$ & 53.1 & 18.6 & 37.3 & 36.8 & 2.6 & 41.0 & 37.2 & 37.1 & 35.9 & 36.7 \\
\hline Other (\%) & 0.3 & 0.4 & 0.3 & 0.4 & 0.8 & 0.3 & 0.7 & 0.3 & 0.1 & 0.3 \\
\hline $\begin{array}{l}\text { Don't know } \\
\text { (\%) }\end{array}$ & 8.6 & 5.6 & 5.8 & 8.6 & 7.9 & 7.1 & 4.3 & 8.9 & 8.3 & 7.2 \\
\hline
\end{tabular}

During the survey, adolescents were asked about mode of counseling support. Table 6.4 represents the distribution of the adolescents who are willing to talk to counselors by mode of support from counselors, age, sex, marital status, and areas. Results show that more than 90 percent of adolescents prefer face-to-face or one-to-one counseling.

Table 6.4: Percentage of adolescents who are willing to talk to counselors by mode of communication, age, sex, marital status, and areas of residence

\begin{tabular}{|c|c|c|c|c|c|c|c|c|c|c|}
\hline \multirow[t]{2}{*}{ Variable } & \multicolumn{2}{|l|}{ Age } & \multicolumn{2}{|l|}{ Sex } & \multicolumn{2}{|c|}{ Marital status } & \multicolumn{4}{|c|}{ City Corporation } \\
\hline & $\begin{array}{l}12-15 \\
\text { years } \\
N=1,837\end{array}$ & \begin{tabular}{|l|}
$16-$ \\
19 \\
years \\
$\mathrm{N}=$ \\
1,669 \\
\end{tabular} & $\begin{array}{l}\text { Boys } \\
N= \\
1,740\end{array}$ & $\begin{array}{l}\text { Girls } \\
N= \\
1,766\end{array}$ & $\begin{array}{l}\text { Ever } \\
\text { married } \\
\mathrm{N}=388\end{array}$ & $\begin{array}{l}\text { Never } \\
\text { married } \\
\mathrm{N}=3,118\end{array}$ & $\begin{array}{c}\text { Dhaka } \\
\text { North } \\
N= \\
1,166\end{array}$ & $\begin{array}{l}\text { Dhaka } \\
\text { South } \\
N= \\
1,168\end{array}$ & $\begin{array}{l}\text { Gazipur } \\
\mathrm{N}=1,172\end{array}$ & $\begin{array}{l}\text { All areas } \\
\mathrm{N}=3,506\end{array}$ \\
\hline $\begin{array}{l}\text { Face-to- } \\
\text { face (\%) }\end{array}$ & 91.7 & 89.9 & 89.8 & 91.8 & 94.6 & 90.3 & 92.0 & 87.2 & 93.2 & 90.8 \\
\hline Skype & 0.4 & 0.8 & 0.6 & 0.6 & 0.3 & 0.6 & 0.7 & 0.9 & 0.2 & 0.6 \\
\hline $\begin{array}{l}\text { Facebook } \\
(\%)\end{array}$ & 1.9 & 4.1 & 4.6 & 1.3 & 0.8 & 3.2 & 4.7 & 3.3 & 0.9 & 2.9 \\
\hline $\begin{array}{l}\text { E-mail } \\
(\%)\end{array}$ & 0.4 & 1.5 & 0.5 & 1.3 & 0.3 & 1.0 & 0.9 & 1.4 & 0.5 & 0.9 \\
\hline Other (\%) & 5.6 & 3.8 & 4.4 & 5.0 & 4.1 & 4.8 & 1.7 & 7.2 & 5.3 & 4.7 \\
\hline
\end{tabular}


Table 6.5 represents the distribution of using helpline counseling by age, sex, marital status, and areas. Results indicate that more than $57 \%$ of respondents want to use helpline counseling for sharing their problems and getting support and that there is a huge need for such support.

Table 6.5: Percentage distribution of adolescents surveyed using helpline counseling, by age, sex, marital status, and area of residence

\begin{tabular}{|c|l|l|l|l|l|l|r|r|r|r|}
\hline Variable & Age & \multicolumn{2}{l|}{ Sex } & \multicolumn{2}{l|}{ Marital status } & \multicolumn{3}{|c|}{ City corporation } \\
\hline & $\begin{array}{l}12-15 \\
\text { years } \\
\mathrm{N}=1,872\end{array}$ & $\begin{array}{l}16-19 \\
\text { years } \\
\mathrm{N}=1,697\end{array}$ & $\begin{array}{l}\text { Boys } \\
\mathrm{N}= \\
\mathbf{1 , 7 7 4}\end{array}$ & $\begin{array}{l}\text { Girls } \\
\mathrm{N}= \\
1,795\end{array}$ & $\begin{array}{l}\text { Ever } \\
\text { married } \\
\mathrm{N}=396\end{array}$ & $\begin{array}{l}\text { Never } \\
\text { married } \\
\mathrm{N}=3,173\end{array}$ & $\begin{array}{c}\text { Dhaka } \\
\text { North } \\
\mathrm{N}=1,196\end{array}$ & $\begin{array}{c}\text { Dhaka } \\
\text { South } \\
\mathrm{N}=1,184\end{array}$ & $\begin{array}{l}\text { Gazipur } \\
\mathrm{N}=1,189\end{array}$ & $\begin{array}{l}\text { All areas } \\
\mathrm{N}=3,569\end{array}$ \\
\hline Yes (\%) & 57.1 & 65.8 & 62.1 & 60.3 & 55.6 & 61.9 & 58.4 & 65.0 & 60.2 & 61.2 \\
\hline No (\%) & 36.2 & 29.8 & 31.5 & 34.1 & 38.1 & 32.5 & 38.0 & 27.9 & 33.6 & 33.1 \\
\hline $\begin{array}{c}\text { Maybe } \\
\text { (\%) }\end{array}$ & 2.5 & 3.2 & 3.1 & 2.6 & 4.8 & 2.6 & 1.8 & 3.6 & 3.1 & 2.8 \\
\hline $\begin{array}{c}\text { Don't } \\
\text { know } \\
\text { (\%) }\end{array}$ & 4.2 & 1.3 & 3.3 & 2.3 & 1.5 & 3.0 & 1.8 & 3.5 & 3.1 & 2.8 \\
\hline
\end{tabular}

\section{COPING STRATEGIES}

Table 6.6 represents the distribution of coping activities that adolescents partake in when they feel upset. Survey results represent that considering age, sex, marital status, and areas of Dhaka City Corporation, most of the adolescents prefer to be on their own when they get upset. They also prefer to listen to music, chat with friends, and sometimes stop talking to others (see Table 6.6).

Table 6.6: Percentage of adolescents surveyed by strategies of coping when they feel upset, age, sex, marital status, and area of residence

\begin{tabular}{|c|c|c|c|c|c|c|c|c|c|c|}
\hline \multirow[t]{2}{*}{ Variable } & \multicolumn{2}{|l|}{ Age } & \multicolumn{2}{|l|}{ Sex } & \multicolumn{2}{|c|}{ Marital status } & \multicolumn{4}{|c|}{ City Corporation } \\
\hline & $\begin{array}{l}12- \\
15 \\
\text { years } \\
\mathrm{N}= \\
1,864\end{array}$ & $\begin{array}{l}16- \\
19 \\
\text { years } \\
\mathrm{N}= \\
1,697\end{array}$ & $\begin{array}{l}\text { Boys } \\
\mathrm{N}= \\
1,770\end{array}$ & $\begin{array}{l}\text { Girls } \\
N= \\
1,791\end{array}$ & $\begin{array}{l}\text { Ever } \\
\text { married } \\
\mathrm{N}=394\end{array}$ & $\begin{array}{l}\text { Never } \\
\text { married } \\
\mathrm{N}=3,167\end{array}$ & $\begin{array}{c}\text { Dhaka } \\
\text { North } \\
N= \\
1,194\end{array}$ & $\begin{array}{l}\text { Dhaka } \\
\text { South } \\
\mathrm{N}= \\
1,180\end{array}$ & $\begin{array}{l}\text { Gazipur } \\
N=1,187\end{array}$ & $\begin{array}{l}\text { All areas } \\
\mathrm{N}=3,561\end{array}$ \\
\hline $\begin{array}{l}\text { Listen to } \\
\text { music (\%) }\end{array}$ & 20.6 & 31.8 & 28.9 & 23.0 & 16.0 & 27.2 & 29.6 & 32.7 & 15.5 & 25.9 \\
\hline $\begin{array}{l}\text { Chat with } \\
\text { friends (\%) }\end{array}$ & 10.0 & 10.7 & 14.0 & 6.6 & 6.6 & 10.8 & 9.2 & 9.8 & 11.9 & 10.3 \\
\hline $\begin{array}{l}\text { Write in a } \\
\text { diary (\%) }\end{array}$ & 0.7 & 1.5 & 1.2 & 0.9 & 0.3 & 1.2 & 1.8 & 0.9 & 0.5 & 1.1 \\
\hline $\begin{array}{l}\text { Be on my } \\
\text { own (\%) }\end{array}$ & 41.1 & 36.4 & 37.2 & 44.4 & 44.2 & 38.2 & 40.0 & 31.9 & 44.5 & 38.8 \\
\hline $\begin{array}{l}\text { Stop eating } \\
\text { (\%) }\end{array}$ & 5.4 & 3.1 & 2.5 & 6.0 & 4.8 & 4.2 & 1.7 & 4.7 & 6.6 & 4.3 \\
\hline $\begin{array}{l}\text { Stop talking } \\
\text { to others }(\%)\end{array}$ & 16.7 & 12.3 & 12.2 & 17.0 & 21.6 & 13.7 & 13.0 & 15.0 & 15.8 & 14.6 \\
\hline $\begin{array}{l}\text { Say prayers } \\
\text { (\%) }\end{array}$ & 0.6 & 0.9 & 0.7 & 0.8 & 0.5 & 0.8 & 0.8 & 0.8 & 0.7 & 0.8 \\
\hline Other (\%) & 4.9 & 3.4 & 3.2 & 5.1 & 6.1 & 3.9 & 3.9 & 4.1 & 4.5 & 4.2 \\
\hline
\end{tabular}


Though risky behavior and substance or drug abuse are social problems, it is an important measure of adolescents' well-being. There may be different reasons why adolescents and young people smoke, take

drugs, or live unhealthy lifestyles. Survey results indicate that most of the adolescents do not smoke (89.2\%) or take drugs (96.4\%)). Only 10.8 and 3.6 percent of adolescents have smoked and taken drugs or alcohol, respectively. Adolescents who smoke or take drugs report that they do it because of getting the experience, peer pressure, stress, and image.

\section{SUMMARY AND CONCLUSIONS}

Assessments of mental health suggest that depression is an important area of concern. Using the 21-point Beck Depression Inventory, the analysis finds higher levels of moderate to severe depression by orphanhood status, experience of violence, poor school performance, and traumatic experiences in childhood. Pregnancy and childbearing are also associated with higher levels of depression among girls. Higher levels of depression are associated with frequency of praying, listening to music, and drug use, suggesting these are coping strategies. Responses to a direct question on what counseling topics would be of most interest suggest that professional help to reduce career- and education-related stress is an important area for unmarried adolescents, while SRHR and relationship concerns are important for married adolescents. 


\title{
Chapter 7 Livelihoods
}

\author{
MD. ABUL KALAM
}

In Bangladesh, many adolescents become full-fledged economic actors during adolescence in ways that are reflected in their engagement in employment, savings habits and expenditure patterns, and asset accumulation. Healthy transitions to adulthood require striking the right balance between engaging in livelihood activities versus investing in education and skills that can allow individuals to become more productive in the future. In many situations, adolescents need to engage in livelihood activities to contribute to their family's income. Indeed, many adolescents spend their childhoods working rather than going to school where they are at risk of violence and exploitation. More than half of the adolescent boys (52.5\%) and $11.3 \%$ of the adolescent girls were reported to be employed in the BDHS survey in 2011 (NIPORT, Mitra and Associates, and ICF International 2013).

\section{WORK PROFILE}

Figure 7.1 presents the distribution of all the adolescents under study according to their schooling and work status and sex. Data revealed that $19.7 \%$ were engaged in only work, $60.2 \%$ were currently enrolled in school, $6.0 \%$ were currently enrolled in school as well as engaged in work, and $14.1 \%$ were doing nothing. More boys than girls were engaged in only work, were enrolled in school, and were enrolled in school as well as engaged in work, while more girls than boys were doing nothing.

Figure 7.1: Distribution of adolescents according to their schooling and work status and sex

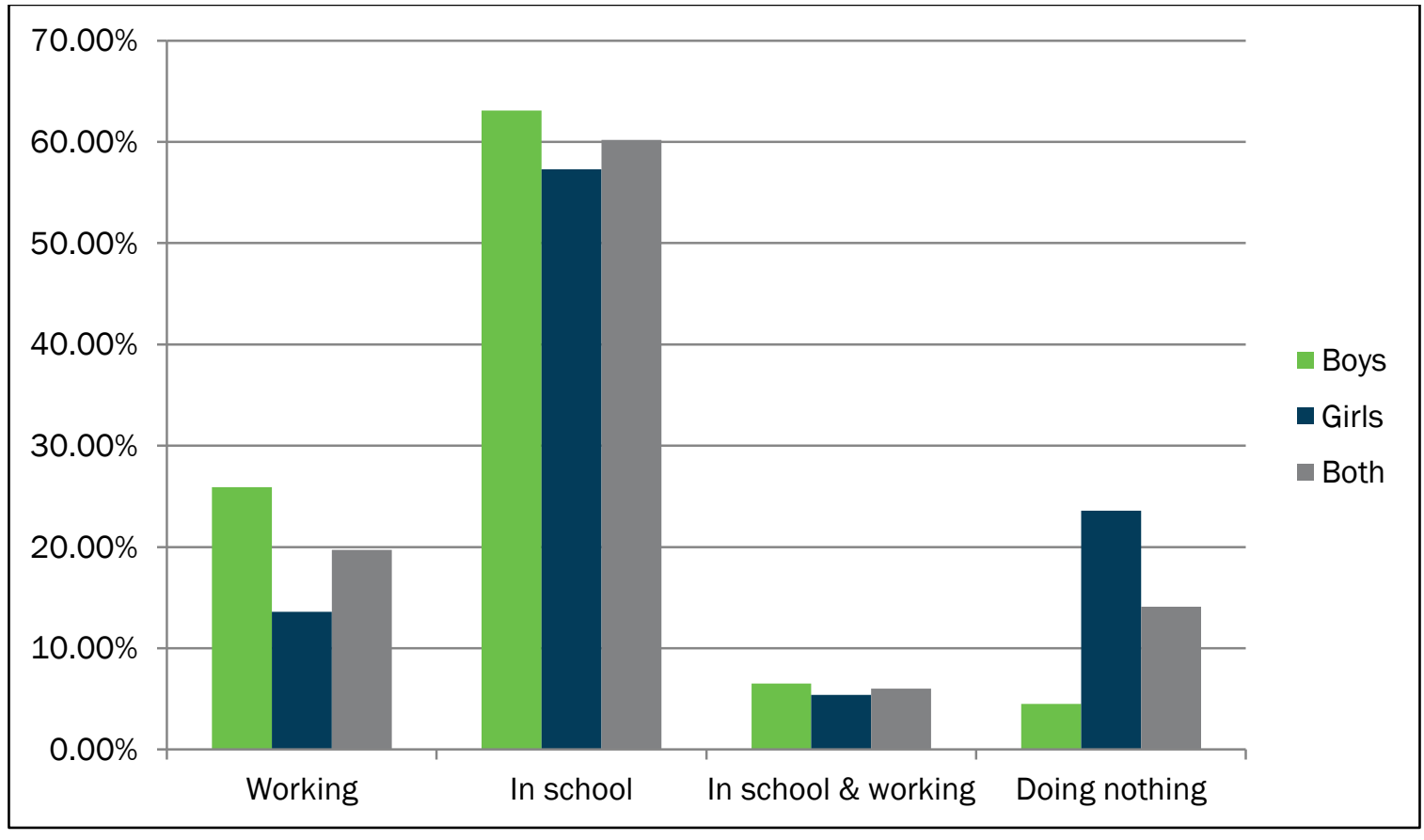


Table 7.1 presents the distribution of adolescents by their working status, occupation, average hours worked, other sources of income, and by sex, age group, and marital status. Data indicated that less than one-third of the 12-19-year-old urban adolescents ever worked for pay and slightly more than one-fourth were currently working. The rate the adolescents who ever worked and who currently worked for pay was comparatively higher among the boys (35.7\% and $32.4 \%$, respectively) than among the girls $(24.7 \%$ and $19.1 \%$, respectively). Among the currently working adolescents, most of the boys were engaged with salaried jobs (22.5\%) followed by business/shopkeeper (19.6\%), mechanics (14.4\%), garment worker (9.5\%), teacher/tutor (8.4\%), and day laborer (7.1\%), while most of the girls were engaged as garment workers (39.5\%) followed by teacher/tutor (27.0\%), house maid (12.8\%), salaried job (8.7\%), and tailoring (2.9\%). Boys had to work longer hours in a week than girls, and they also earned significantly more than girls in a given time. The proportion of adolescents who had sources of income other than their occupation was higher among the girls (71.9\%) than among the boys (67.7\%), but average monthly income from these sources was comparatively higher among the boys than the girls. The proportion of adolescents who have ever worked or are currently working was higher among the older age group of 16-19 years compared to the younger age group of 12-15 years. Average hours worked in a week was slightly higher among the younger age group 12-15, while the monthly income was higher for older groups than the younger group. Working status, occupation, working hours, sources of income other than occupation, and income varied according to the marital status of the adolescents. The proportion of adolescents who ever worked for pay was slightly higher among the ever-married adolescents, while the proportion of adolescents who were currently working was higher among the never-married adolescents (Table 7.1).

Table 7.1: Percentage of adolescents surveyed by their work profile, sex, age group, and marital status

\begin{tabular}{|l|c|c|c|c|c|c|c|}
\hline \multirow{2}{*}{ Work issues } & \multicolumn{2}{|c|}{ Sex (\%) } & \multicolumn{2}{c|}{ Age group (\%) } & \multicolumn{2}{c|}{ Marital status (\%) } & \multirow{2}{*}{ All } \\
\cline { 2 - 6 } & Boys & Girls & $\begin{array}{c}12-15 \\
\text { years }\end{array}$ & $\begin{array}{c}16-19 \\
\text { years }\end{array}$ & $\begin{array}{c}\text { Ever } \\
\text { married }\end{array}$ & $\begin{array}{c}\text { Never } \\
\text { married }\end{array}$ & \\
\hline Ever worked for pay & 35.7 & 24.7 & 17.5 & 44.2 & 31.2 & 30.1 & 30.2 \\
\hline Currently working & 32.4 & 19.1 & 15.0 & 37.5 & 20.1 & 26.4 & 25.7 \\
\hline $\mathrm{N}$ & 1,782 & 1,803 & 1,881 & 1,704 & 398 & 3,187 & 3,585 \\
\hline Occupation & & & & & & & \\
\hline Teacher/tutor & 8.4 & 27.0 & 5.3 & 19.6 & 12.5 & 15.5 & 15.2 \\
\hline Service/salary paid & 22.5 & 8.7 & 17.7 & 17.2 & 11.3 & 18.0 & 17.4 \\
\hline Business/shopkeeper & 19.6 & 0.3 & 11.3 & 13.0 & 2.5 & 13.4 & 12.5 \\
\hline Mechanics & 14.4 & 0.9 & 10.6 & 8.8 & 3.8 & 9.9 & 9.3 \\
\hline Garment worker & 9.5 & 39.5 & 20.1 & 21.0 & 40.0 & 18.9 & 20.7 \\
\hline House maid & 1.0 & 12.8 & 11.0 & 3.0 & 10.0 & 5.0 & 5.4 \\
\hline $\begin{array}{l}\text { Poultry/ag. work/labor/ } \\
\text { cottage industry }\end{array}$ & 1.4 & 2.0 & 0.7 & 2.0 & 7.5 & 1.1 & 1.6 \\
\hline Parlor worker & & & & & & & \\
\hline Tailor & 0.0 & 0.6 & 0.4 & 0.2 & 0.0 & 0.2 & 0.2 \\
\hline Day laborer & 0.3 & 2.9 & 1.1 & 1.4 & 2.5 & 1.2 & 1.3 \\
\hline Other & 7.1 & 0.6 & 7.1 & 3.6 & 1.3 & 5.0 & 4.7 \\
\hline $\mathrm{N}$ & 15.8 & 4.7 & 14.8 & 10.2 & 8.8 & 11.9 & 11.6 \\
\hline Average weekly working hours & 577 & 345 & 282 & 640 & 80 & 842 & 922 \\
\hline Average weekly income (BDT) & 50.29 & 40.18 & 47.36 & 46.15 & 46.20 & 46.42 & 46.37 \\
\hline Average hourly rate of income & $1,456.85$ & 992.81 & 996.31 & $1,411.01$ & $1,365.15$ & $1,275.98$ & $1,283.72$ \\
\hline Average monthly income (BDT) & 28.9 & 24.7 & 21.0 & 30.5 & 29.5 & 27.4 & 27.6 \\
\hline $\mathrm{N}$ & $5,841.56$ & $3,978.81$ & $4,002.40$ & $5,653.29$ & $5,448.13$ & $5,117.91$ & $5,146.56$ \\
\hline Have other source of income & 577 & 345 & 282 & 640 & 80 & 842 & 922 \\
\hline $\mathrm{N}$ & 67.7 & 71.9 & 74.5 & 64.7 & 73.6 & 69.4 & 69.8 \\
\hline Other sources of income* & 1,782 & 1,803 & 1,881 & 1,704 & 398 & 3,187 & 3,585 \\
\hline Family & & & & & & & \\
\hline Relatives & 95.9 & 92.8 & 94.7 & 93.7 & 88.4 & 95.1 & 94.3 \\
\hline Scholarship & 10.4 & 11.3 & 11.6 & 10.1 & 5.8 & 11.6 & 10.9 \\
\hline $\begin{array}{l}\text { Average monthly income from other } \\
\text { sources (BDT) }\end{array}$ & 0.7 & 0.7 & 0.9 & 0.5 & 0.3 & 0.7 & 0.7 \\
\hline
\end{tabular}

*Multiple responses. 
Currently working adolescents were found to be engaged in a variety of occupational activities. The highest (20.7\%) proportion of the adolescents were involved with working in garment factories, followed by salaried job (17.4\%), teacher/tutor-mainly private tuition (15.2\%), business/shopkeeper (12.5\%), mechanics (9.3\%), house maid (5.4\%), and day labor (4.7\%). The highest proportion of the adolescents in Dhaka North (18.4\%) were involved with teaching or tutoring followed by a salaried job (15.6\%), working in garment factories (15.2\%), business/shopkeeper and house maid (14.5\% each), and mechanics (5.9\%). In Dhaka South, most of the adolescents (21.9\%) were involved with a salaried job followed by teacher/tutor (18.3\%), mechanics (15.9\%), business/shopkeeper (14.4\%), garment worker (7.5\%), and day laborer (4.8\%). The highest (38.3\%) were involved with working in garment factories followed by salaried job (14.2\%), teacher/tutor (9.6\%), business/shopkeeper (9.0\%), day laborer (6.0\%), and mechanics (5.4\%). Currently working adolescents worked on average 46 hours 37 minutes a week, and it varied according to areas. On average, the adolescents earned Tk5,147 a month, which also varied according to area. More than two-thirds of the adolescents have sources of income other than their occupation, and the source most adolescents received income from was the family followed by relatives. The adolescents got on average Tk1,497 per month from sources other than their occupation (Table 7.1).

\section{ASSET OWNERSHIP}

Table 7.2 shows the distribution of adolescents by ownership of selected assets, sex, age group, and marital status. It was found that very few of the adolescents owned any productive asset except land, and about one-third had unproductive assets like gold and silver. More girls than boys owned assets. Most of the boys owned computers $(12.5 \%)$, followed by land $(10.2 \%)$, bicycle $(8.2 \%)$, and gold $(7.6 \%)$, while most girls owned gold (62.6\%), followed by silver (52.0\%), land (17.1\%), computers (7.4\%), and poultry (6.8\%). Higher proportions of the older age group owned all the assets, except a bicycle, compared with the younger age group. Among adolescents who were ever married, higher proportions owned all the assets, except computer and bicycle, compared with those never married (Table 7.2).

Table 7.2: Percentage of adolescents surveyed by their asset-ownership profile, sex, age group, and marital status

\begin{tabular}{|l|c|c|c|c|c|c|c|}
\hline \multirow{2}{*}{ Own assets* } & \multicolumn{2}{|c|}{ Sex (\%) } & \multicolumn{2}{c|}{ Age group (\%) } & \multicolumn{2}{c|}{ Marital status (\%) } & \multirow{2}{*}{ All (\%) } \\
\cline { 2 - 7 } & Boys & Girls & $\begin{array}{c}12-15 \\
\text { years }\end{array}$ & $\begin{array}{c}16-19 \\
\text { years }\end{array}$ & $\begin{array}{c}\text { Ever } \\
\text { married }\end{array}$ & $\begin{array}{c}\text { Never } \\
\text { married }\end{array}$ & \\
\hline Land & 10.2 & 17.1 & 13.3 & 14.0 & 19.3 & 12.9 & 13.6 \\
\hline Cow & 2.0 & 4.1 & 2.9 & 3.3 & 7.0 & 2.6 & 3.1 \\
\hline Sheep/goat & 1.5 & 3.1 & 2.3 & 2.2 & 4.8 & 1.9 & 2.3 \\
\hline Poultry & 4.5 & 6.8 & 5.3 & 6.0 & 10.1 & 5.1 & 5.7 \\
\hline Computer & 12.5 & 7.4 & 6.9 & 13.3 & 3.8 & 10.7 & 9.9 \\
\hline Bicycle & 8.2 & 3.7 & 6.3 & 5.5 & 3.5 & 6.2 & 5.9 \\
\hline Gold & 7.6 & 62.6 & 30.9 & 40.1 & 74.6 & 30.3 & 35.3 \\
\hline Silver & 4.8 & 52.0 & 25.7 & 31.6 & 57.5 & 24.9 & 28.5 \\
\hline $\mathrm{N}$ & 1,782 & 1,803 & 1,881 & 1,704 & 398 & 3,187 & 3,585 \\
\hline
\end{tabular}

*Multiple responses.

\section{EXPENDITURE PROFILE}

Table 7.3 shows the distribution of adolescents by their expenditure profile and by work and marital status. Respondents were asked to mention three things they spent the most money on in the last one month. Expenditure profiles varied among currently working and nonworking adolescents as well as according to their marital status. About three-fifths of the working adolescents spent money for contributions to the family, followed by own transport costs (38.2\%), mobile bill (35.4\%), clothes (34.9\%), food (30.5\%), and savings (21.0\%), while two-fifths of the nonworking adolescents spent money for food, followed by own transport costs (36.5\%), school fees (31.1\%), cosmetics (29.8\%), clothes (27.9\%), and books (19.6\%). Ever- 
married adolescents spent more on contributions to family, savings, medicine, clothes, and cosmetics, while never-married adolescents spent more on all the other expenses (Table 7.3).

Table 7.3: Percentage of adolescents surveyed by their expenditure profile, work status, and marital status

\begin{tabular}{|l|c|c|c|c|c|c|c|}
\hline \multirow{2}{*}{ Expenses* } & \multicolumn{3}{|c|}{ Working (\%) } & \multicolumn{3}{c|}{ Nonworking (\%) } & \multirow{2}{*}{ All (\%) } \\
\cline { 2 - 7 } & $\begin{array}{c}\text { Ever } \\
\text { married }\end{array}$ & $\begin{array}{c}\text { Never } \\
\text { married }\end{array}$ & All & $\begin{array}{c}\text { Ever } \\
\text { married }\end{array}$ & $\begin{array}{c}\text { Never } \\
\text { married }\end{array}$ & All & \\
\hline Contribution to family & 70.0 & 58.8 & 59.8 & 40.9 & 8.6 & 12.4 & 24.6 \\
\hline Savings & 33.8 & 19.8 & 21.0 & 35.2 & 17.0 & 19.2 & 19.6 \\
\hline Own transport costs & 26.3 & 39.3 & 38.2 & 10.7 & 40.0 & 36.5 & 36.9 \\
\hline School fees & 1.3 & 7.7 & 7.2 & 2.8 & 34.9 & 31.1 & 24.9 \\
\hline Books & 0.0 & 4.3 & 3.9 & 1.9 & 22.0 & 19.6 & 15.6 \\
\hline Medicine & 8.8 & 3.9 & 4.3 & 17.6 & 3.5 & 5.1 & 4.9 \\
\hline Mobile telephone bill & 22.5 & 36.6 & 35.4 & 20.1 & 15.5 & 16.1 & 21.0 \\
\hline Clothes & 48.8 & 33.6 & 34.9 & 45.6 & 25.5 & 27.9 & 29.7 \\
\hline Cosmetics & 33.8 & 17.5 & 18.9 & 51.3 & 26.9 & 29.8 & 27.0 \\
\hline Entertainment & 2.5 & 6.1 & 5.7 & 5.3 & 10.6 & 10.0 & 8.9 \\
\hline Travel/visiting places & 3.8 & 11.4 & 10.7 & 5.3 & 12.5 & 11.6 & 11.4 \\
\hline Repay loan & 2.5 & 4.0 & 3.9 & 3.1 & 0.8 & 1.1 & 1.8 \\
\hline Investment in business & 1.3 & 1.8 & 1.7 & 0.0 & 0.2 & 0.2 & 0.6 \\
\hline Food & 18.8 & 31.6 & 30.5 & 23.0 & 43.5 & 41.0 & 38.3 \\
\hline Other & 3.8 & 2.0 & 2.2 & 2.5 & 5.1 & 4.8 & 4.1 \\
\hline N & 80 & 842 & 922 & 318 & 2,345 & 2,663 & 3,585 \\
\hline
\end{tabular}

*Multiple responses.

Table A7.1 in the annex presents the distribution of adolescents by their expenditure profile, sex, and age group. More boys than girls spent on contributions to family, their own transport costs, school fees, books, mobile bill, entertainment, travel/visiting places, and food, while more girls than boys spent on all the other expenditures. In case of age groups, more adolescents from the younger group of 12-15-year-olds spent on savings, school fees, books, entertainment, travel/visiting places, and food, while more adolescents from the older group of 16-19-year-olds spent on all the other expenditures.

\section{SKILL TRAINING PROFILE}

Table 7.4 presents the distribution of adolescents by their skill training profile, sex, age group, and marital status. It was found from the data that a very negligible proportion had received any skill training. More boys than girls, more older adolescents than younger ones, and more never-married than ever-married adolescents received different skill training. More boys than girls received training on financial literacy, computer and mobile repairing, English language, web searching, resume development, job searching through the Internet, and seeking an outsourcing job, while more girls than boys received training on garment work, mathematics, and interview techniques. More adolescents from the older group of 16-19year-olds received training on all the skills. More never-married adolescents received training on all the skills except garment work (Table 7.4). 
Table 7.4: Percentage of adolescents surveyed by their skill-training profile, sex, age group, and marital status

\begin{tabular}{|l|c|c|c|c|c|c|c|}
\hline \multirow{2}{*}{ Type of skill training* } & \multicolumn{2}{|c|}{ Sex (\%) } & \multicolumn{2}{c|}{ Age group (\%) } & \multicolumn{2}{c|}{ Marital status (\%) } & \multirow{2}{*}{ All (\%) } \\
\cline { 2 - 7 } & Boys & Girls & $\begin{array}{c}12-15 \\
\text { years }\end{array}$ & $\begin{array}{c}16-19 \\
\text { years }\end{array}$ & $\begin{array}{c}\text { Ever } \\
\text { married }\end{array}$ & $\begin{array}{c}\text { Never } \\
\text { married }\end{array}$ & \\
\hline Financial literacy & 0.2 & 0.0 & 0.1 & 0.1 & 0.0 & 0.1 & 0.1 \\
\hline Computer and mobile repairing & 2.5 & 2.0 & 0.7 & 4.0 & 1.3 & 2.4 & 2.3 \\
\hline Garment work & 0.7 & 1.8 & 0.7 & 1.9 & 1.8 & 1.2 & 1.3 \\
\hline English language & 0.6 & 0.5 & 0.2 & 1.0 & 0.0 & 0.6 & 0.6 \\
\hline Mathematics & 0.0 & 0.2 & 0.1 & 0.1 & 0.0 & 0.1 & 0.1 \\
\hline Web searching & 0.8 & 0.1 & 0.0 & 0.9 & 0.0 & 0.5 & 0.4 \\
\hline Resume development & 0.7 & 0.4 & 0.2 & 0.9 & 0.0 & 0.6 & 0.5 \\
\hline Interview techniques & 0.0 & 0.1 & 0.1 & 0.0 & 0.0 & 0.1 & 0.1 \\
\hline Job searching through Internet & 0.5 & 0.1 & 0.0 & 0.6 & 0.0 & 0.3 & 0.3 \\
\hline Seeking outsourcing job & 0.4 & 0.0 & 0.1 & 0.4 & 0.0 & 0.3 & 0.3 \\
\hline $\mathrm{N}$ & 1,782 & 1,803 & 1,881 & 1,704 & 398 & 3,187 & 3,585 \\
\hline
\end{tabular}

*Multiple responses.

\section{SUMMARY AND CONCLUSIONS}

About one in every three adolescents work: over one-third of boys and just about one in four girls. Servicesector salaried jobs are the dominant occupation for boys, and the garment industry accounts for almost one-third of all working adolescent girls. Tutoring is much more common among girls than boys in this urban population. As was seen in the BALIKA survey, tutoring was a major sector of work for rural girls. Girls work an average of 40 hours and boys an average of 50 hours per week, but boys earn $50 \%$ more. Workforce participation is highest among adolescents who have never been to school. Expenditure patterns vary for boys and girls and by marital status. Boys report contribution to family support more often than girls. Adolescents in school report spending mostly on education and travel-related expenses. Descriptions of adolescents' assets show that girls primarily hold their assets in the form of gold or silver, and this is common in all three study areas. Asset holdings in gold rise with education and is highest in the area that is the most prosperous, i.e. Dhaka North. These data suggest that adolescents in Bangladesh remain fairly conservative and traditional in terms of their asset management. Holding assets in the form of gold is the traditional way in which women hold assets.

Tutoring is the primary means of earning for adolescents in school. For boys, working in stores and in mechanic shops is also common, although less so than tutoring. For girls, tutoring appears to be the only option. A small minority also report working in the garment sector, but barely anyone reports working as domestic help while going to school. Thus, other than tutoring, most sectors of work for girls are not compatible with school attendance. 
Annex A7.1: Percentage of adolescents surveyed by their expenditure profile, sex, and age group

\begin{tabular}{|c|c|c|c|c|}
\hline \multirow[t]{2}{*}{ Expenses* } & \multicolumn{2}{|c|}{ Sex (\%) } & \multicolumn{2}{|c|}{ Age group (\%) } \\
\hline & Boys & Girls & $\begin{array}{l}12-15 \\
\text { years }\end{array}$ & $\begin{array}{l}16-19 \\
\text { years }\end{array}$ \\
\hline Contribution to family & 26.3 & 22.9 & 16.8 & 33.2 \\
\hline Savings & 14.5 & 24.7 & 19.9 & 19.3 \\
\hline Own transport cost & 46.0 & 28.0 & 33.0 & 41.3 \\
\hline School fee & 27.3 & 22.6 & 31.3 & 18.0 \\
\hline Books & 16.2 & 15.0 & 19.8 & 10.9 \\
\hline Medicine & 3.0 & 6.9 & 3.4 & 6.6 \\
\hline Mobile bill & 29.5 & 12.65 & 9.3 & 34.0 \\
\hline Clothes & 19.8 & 39.4 & 26.5 & 33.2 \\
\hline Cosmetics & 8.8 & 45.8 & 25.3 & 28.9 \\
\hline Entertainment & 14.1 & 3.7 & 10.5 & 7.2 \\
\hline Travel/visiting places & 17.8 & 5.1 & 12.4 & 10.3 \\
\hline Repay loan & 1.8 & 1.8 & 1.5 & 2.1 \\
\hline Investment in business & 1.0 & 0.2 & 0.4 & 0.8 \\
\hline Food & 42.8 & 33.9 & 48.3 & 27.3 \\
\hline Other & 4.2 & 4.0 & 4.8 & 3.3 \\
\hline $\mathrm{N}$ & 1,782 & 1,803 & 1,881 & 1,704 \\
\hline \multirow[t]{2}{*}{ Work issues } & \multicolumn{3}{|c|}{ Schooling Status (\%) } & \multirow{2}{*}{ All } \\
\hline & $\begin{array}{c}\text { Never } \\
\text { enrolled }\end{array}$ & In school & $\begin{array}{l}\text { Out of } \\
\text { school }\end{array}$ & \\
\hline Ever worked for pay & 73.9 & 12.6 & 63.7 & 30.2 \\
\hline Currently working & 66.9 & 9.1 & 57.4 & 25.7 \\
\hline $\mathrm{N}$ & 115 & 2,372 & 1,098 & 3,585 \\
\hline \multicolumn{5}{|l|}{ Occupation } \\
\hline Teacher/tutor & 0.0 & 56.3 & 3.0 & 15.2 \\
\hline Service/salary paid & 19.5 & 9.8 & 19.7 & 17.4 \\
\hline Business/shopkeeper & 7.8 & 12.1 & 13.2 & 12.5 \\
\hline Mechanics & 10.4 & 3.7 & 11.1 & 9.3 \\
\hline Garments worker & 16.9 & 4.2 & 26.9 & 20.7 \\
\hline House maid & 24.7 & 0.5 & 4.8 & 5.4 \\
\hline Poultry/ag.work/labor/cottage industry & 2.6 & 1.9 & 1.4 & 1.6 \\
\hline Parlor worker & 0.0 & 0.0 & 0.3 & 0.2 \\
\hline Tailoring & 0.0 & 0.9 & 1.6 & 1.3 \\
\hline Day labor & 11.7 & 2.3 & 4.6 & 4.7 \\
\hline Other & 6.5 & 8.4 & 13.4 & 11.6 \\
\hline $\mathrm{N}$ & 77 & 215 & 639 & 921 \\
\hline Average weekly working hour & 51.48 & 23.49 & 53.49 & 46.37 \\
\hline Average weekly income (BDT) & $1,105.97$ & 868.42 & $1,447.17$ & $1,283.72$ \\
\hline Average monthly income (BDT) & $4,425.19$ & $3,484.47$ & $5,801.95$ & $5,146.56$ \\
\hline Have other source of income & 36.5 & 81.9 & 47.3 & 69.8 \\
\hline \multicolumn{5}{|l|}{ Other sources of income* } \\
\hline Family & 90.5 & 95.7 & 89.2 & 94.3 \\
\hline Relatives & 4.8 & 11.4 & 9.6 & 10.9 \\
\hline Scholarship & 0.0 & 0.8 & 0.0 & 0.7 \\
\hline $\mathbf{N}$ & 42 & 1,943 & 519 & 2,504 \\
\hline Average monthly income (BDT) from other sources & 697.55 & $1,596.75$ & $1,187.95$ & $1,496.94$ \\
\hline
\end{tabular}

*Multiple responses. BDT = Bangladeshi Taka. 


\section{Chapter 8 Conclusions}

\section{SAJEDA AMIN}

The Urban Adolescents Needs Assessment Survey was designed to provide general information on urban adolescents and specific recommendations for those designing programs and policies for adolescents living in urban areas. The survey was conducted in six thanas located in and near Dhaka city from April to May 2014. The sample includes adolescent girls and boys aged 12-19 sampled from, and interviewed in, their homes. The total sample size is 3,585 and includes married and unmarried adolescents.

This report presents data broken down by age, sex, marital status, and area of residence to note patterns of variation that can be taken into account in designing programs and policies for vulnerable groups. Although the data document that education levels are rising in urban Bangladesh, and relative to their parents adolescents are much more likely to be educated, lack of access to education remains an important deprivation to a significant minority of adolescents living in the city. Boys and girls who drop out are most likely to say that caring for siblings or others was the primary reason. This suggests that the provision of child-care support to households may reap important benefits for adolescent retention in school. A second important cause of dropout is early marriage for girls. The urban child marriage rates documented in this study are at the same level as rates of child marriage reported from three rural districts having the highest rates of child marriage in the country. Programs to address child marriage must target urban as well as rural areas. A high proportion of boys cite a lack of interest in studies as their reason for dropping out. Programs should explore ways of making education relevant and interesting. The study suggests that resources such as libraries and computer laboratories are underutilized. Utilizing these resources may be a way of making education interesting and relevant for adolescents.

Nearly one in three of the fathers and mothers have never attended school, however the percentage of adolescents who have never been to school in this sample is less than 4\%. Programs may want to consider that many adolescents attending school live in households with no literate adults. For adolescents to benefit from schooling, schools must ensure that adolescents have access to educated and trusted adults who can support them in their educational pursuits by designing mentoring programs that will serve these needs.

Although girls who are in school have slightly higher levels of achievement than boys, they tend to drop out after puberty and thus attain lower overall levels of schooling than boys, with marriage given as the reason for school dropout for more than one-third of girls who drop out. There are two predominant reasons given for marriage-by far the most common is that parents and guardians decided a proposal was too good to refuse. Programs to address school dropout must find ways of engaging parents of girls who are at risk to provide relevant information, including the risks associated with child marriage. About one in four adolescent girls report that they chose to marry of their own accord despite the fact that the overwhelming majority of adolescents thought it was ideal to marry at later ages. There is clear discordance between ideals and reality. Programs need to explore ways to change the way adolescents themselves view the option of marriage.

Very few urban adolescents report receiving stipend support for education, and this is because national stipend programs do not cover urban areas. While the lack of support has not precluded the majority of girls and boys from entering school, the proportion of urban adolescents who have never attended school is around 4\%, which is higher than the 1\% in rural areas (Amin et al. 2014). Furthermore, this number is an underestimate given that the sample of adolescents are living in households and the survey likely does not capture the children not living in households, such as street children or institutionalized children who are 
likely to be at greater risk of never going to school. The data on workforce participation suggests that those who have never attended school and those who are no longer in school work very long hours (over 50 hours on average). It is likely that these children can be catered to at their place of work. It is also likely that their need to earn is strong and any provision of education and literacy programs has to accommodate those needs.

Four out of five adolescents pay for private tutoring, mostly in English and mathematics. Assessments of learning suggest that the quality of schooling is poor, particularly for mathematics. Overall about $13 \%$ of adolescents have repeated a grade, with about $50 \%$ among them repeating because they have failed the final examination. Most adolescents are able to read well in Bangla, their native language. English language competency is better in urban than in rural areas. It is likely that programs for distance learning through television and mobile platforms can play a role given that most adolescents have access to television and mobile phones. The data on tutoring suggest that adolescents (and their families) are strongly motivated to succeed in school and to invest to ensure success. There is room for improvement in school quality. Uneducated mothers are least likely to appoint private tutoring for their children. These data suggest that investments should be made in providing educational support in out-of-school settings. Parents are willing to pay for such support and the objective is to boost success rates.

Assessments of learning competencies on a range of indicators suggest that sex differences and age-related differences are small. However, there are considerable differences by level of schooling completed and by whether adolescents are currently in or out of school, the latter suggesting that adolescents who are no longer in school may lose some of the competencies they attain.

Overall, about one-third of all adolescents work. Boys are more likely to work than girls. However, nearly one in four adolescent girls is engaged in income-earning activities, a ratio that is considerably higher than in rural areas where only 10\% have ever worked (Amin et al. 2014). Boys and girls work in different occupations-while the service sector is the dominant sector of employment for boys, garment factories are the dominant place of work for adolescent girls. Girls who are in school earn by tutoring children. Boys earn $50 \%$ more than girls. Although labor-force participation is highest among the least educated, returns to education are high and even adolescents with incomplete primary education earn more per hour than adolescents with no education.

Indicators related to sexual and reproductive health knowledge and practices suggest that although access to knowledge and services is high for married adolescents, it is nearly nonexistent for unmarried adolescents. There is considerable resistance in national policies to provide SRHR services to unmarried adolescents, a factor that puts these adolescents at considerable risk of childbearing. A little over half of all married girls have ever been pregnant, despite the fact that knowledge of modern contraception is high and most married adolescents have used contraception at some point in their lives. High rates of childbearing with high levels of contraceptive use suggest that there is ineffective use or discontinuation because of sideeffects.

The survey suggests several areas in which investments may be made to change normative attitudes and behaviors, particularly in the context of intimate relationships. Acceptance of violence norms is one such area and gender-role expectations is another. Responses to gender normative questions suggest there is a need to work on changing community norms both among boys and girls. While responses were reasonably gender equitable on the general notions of the right to equitable treatment, responses were more inequitable in terms of acceptance of norms of violence toward women, inequitable role expectations, and male dominance in matters of domestic decision-making.

In several dimensions, the survey failed to replicate results reported in other surveys. In particular, reported levels of experience of harassment and violence were much lower in this survey compared with past studies in urban Bangladesh. Reports of drug use and sexual activity outside marriage were also low, as was the percentage of marriage reported to involve dowry. It may be the case that the survey underreported all of these behaviors, suggesting that it is important to offer higher levels of privacy and anonymity than what the current survey was able to provide. There are other ways in which the survey did replicate results from other recently conducted studies. The results reported by the current study on measures of gender inequitable values and norms suggest that urban adolescents are similar to rural adolescents in their values. The 
majority held that girls should begin practicing purdah at a young age. Boys are somewhat more likely than girls to hold such values.

Finally, the survey identifies mental health as an important area of concern. An assessment using the Beck Depression Inventory identifies moderate to high levels of depression. Depression is associated with orphanhood, school performance, drug use, and the experience of violence, as well as to listening to the radio and praying. These may be either causes or consequences of depression and the data is not able to identify direction of causality. Nevertheless, these associations are important for strategies that target resources and for designing mental health interventions.

The survey-through its detailed exploration of schooling outcomes and work, and its questions on reproductive and sexual health knowledge and the social lives of adolescents-suggests several distinct and identifiable target groups: adolescents in school, adolescents at work, and married adolescents. Programs may want to consider these distinct groups and address their specific needs and vulnerabilities. In general, adolescent programs would do well to recognize the vast heterogeneity among adolescents and consider these three distinct groups and their specific needs. 


\section{REFERENCES}

Ahmed, Manzoor, Kazi Saleh Ahmed, Nurul Islam Khan, and Romij Ahmed. 2007. "Access to Education in Bangladesh: Country Analytic Review of Primary and Secondary Education," Institute of Educational Development. Dhaka: BRAC University.

Ali, Tariq Omar, Nuzhat Imam, Raihana Karim, and Nasheeba Selim. 2006. "Voices of the Youth: Findings from Youth Consultations in Bangladesh." Dhaka: BRAC Research and Evaluation Division.

Amin, Sajeda et al. 2013. "The Adolescent Girls Vulnerability Index: Guiding Strategic Investment in Uganda." New York: Population Council.

Amin, Sajeda et al. 2014. "The Lives of Rural Adolescent Girls in Southern Bangladesh. Results from the 2013 Baseline Survey for the BALIKA Project: From Evidence to Action." Dhaka: Population Council.

Amin, Sajeda and Lopita Huq. 2008. "Marriage Considerations in Sending Girls to School in Bangladesh: Some Qualitative Evidence," Poverty, Gender, and Youth Working Paper No. 12. New York: Population Council.

Amin, Sajeda, Laila Rahman, and Irfan Hossain. 2012. "Baseline Survey Report on Sexual and Reproductive Health and Rights and Violence Against Women and Girls in Dhaka Slums: Marriage and Dowry," Working Paper No. 176. Dhaka: icddr,b.

BBS and UNICEF. 2010. "Multiple Indicator Cluster Survey 2009. "Monitoring the Situation of Children and Women, Progotir Pathey 2009," Vol. 1: Technical Report. Dhaka: Bangladesh Bureau of Statistics and UNICEF.

Beck, A.T., R.A. Steer, G.K. Brown. 1996. "Manual for the Beck Depression Inventory-II." San Antonio, TX: Psychological Corporation.

BIED, BRAC U. 2012. “Adolescents' Life in Dhaka: Needs Assessment of Adolescent Girls and Boys in Bangladesh," Dhaka: BRAC Institute of Educational Development, BRAC University.

Camellia, Suborna, N.N. Khan, and Ruchira T. Naved. 2012. "Baseline Survey Report on Sexual and Reproductive Health and Rights and Violence Against Women and Girls in Dhaka Slums: Violence Against Unmarried Adolescent Girls," Working Paper No. 176. Dhaka: icddr,b.

Cameron, S. 2011. “Education Decisions in Slums of Dhaka in Education," in Ahmed, M. (ed.) 2011.

Overgrowing Hurdles to Equity with Quality. Dhaka: Institute of Educational Development, BRAC University.

Cochran, W.G. 1977. Sampling Techniques, Singapore: John Wiley and Sons.

Deb, S., E Strodi, and J. Sun. 2015. "Academic Stress, Parental Pressure, Anxiety and Mental Health among Indian High School Students," International Journal of Psychology and Behavioral Sciences, 5(1): 26-34.

Dube, S. and K. Sharma. 2012. "Knowledge, Attitude and Practice Regarding Reproductive Health among Urban and Rural Girls: A Comparative Study," Ethno Med, 6(2): 85-86.

Forero, R., L. McLellan, C. Rissel, and A. Bauman. 1999. "Bullying Behavior and Psychosocial Health among School Students in New South Wales, Australia: Cross Sectional Study," British Medical Journal, 319: 344347.

Humemsky, J., S.A. Kuwabara, J. Fogel, C. Wells, B. Goodwill, and B.W.V. Voorhees. 2010. "Adolescents with Depressive Symptoms and Their Challenges with Learning in School," The Journal of School Nursing, 26(5): 377-392.

Kaltiala-Heino, R., M. Rimpelä, M. Marttunen, A. Rimpelä, P. Rantanen. 1999. “Bullying, Depression and Suicidal Ideation in Finnish Adolescents: School Survey," British Medical Journal, 319: 348-351.

Kalton, G. 1983. "Introduction to Survey Sampling," Sage University Paper series on Quantitative Applications in Social Sciences, 07-035. Newbury, CA: Sage.

Kumar, P., D.K. Nehra, and S. Dahiya. 2013. "Women Empowerment and Mental Health: A Psychological Aspect," Delhi Psychiatry Journal, 16(1): 57-65. 
Lloyd, C. and J. Young. 2009. New Lessons: The Power of Educating Adolescent Girls. New York: Population Council.

Mahmud, Simeen and Sajeda Amin. 2006. "Girls' schooling and marriage in rural Bangladesh," in Emily Hannum, Bruce Fuller (eds.), Research in the Sociology of Education: Children's Lives and Schooling across Societies, Volume 15: pp.71-99.

Ministry of Health and Children Affairs (2009). Teenage Mental Health: What Helps and What Hurts? ISBN: 978-1-4064-2284-9. Olivia McEvoy. Dublin, Ireland.

http://www.dcya.gov.ie/documents/publications/MentalHealthWhatHelpsAndWhatHurts.pdf.

Nasreen, H., Z. Kabir, and M. Edhborg. 2013. "Prevalence and Associated Factors of Depressive Symptoms among Disadvantaged Adolescents in Bangladesh." Dhaka: BRAC-RED and Institute of Education, BRAC University, and Karolinska Institute Sweden.

National Education Policy. 2010. Ministry of Education, Government of the People's Republic of Bangladesh.

National Plan of Action. 2013. "Adolescent Sexual and Reproductive Health." Dhaka: Directorate General of Family planning, Government of the People's Republic of Bangladesh.

NIPORT, Mitra and Associates, and ICF International. 2013. Bangladesh Demographic and Health Survey 2011. Dhaka, Bangladesh and Calverton, Maryland, USA: NIPORT, Mitra and Associates, and ICF International.

Population Census 2011. Bangladesh Bureau of Statistics.

http://www.bbs.gov.bd/PageWebMenuContent.aspx?MenuKey=333.

Rahman, L., Irfan Hossain, and Sajeda Amin. 2012. "Baseline Report on Sexual and Reproductive Health and Rights and Violence Against Women and Girls in Dhaka Slums: Knowledge, Attitude and Practices Associated with Sexual and Reproductive Health and Rights," Working Paper No. 176. Dhaka: icddr,b.

Rashid, S.F. 2011. "Human Rights and Reproductive Health: Political Realities and Pragmatic Choices for Married Adolescent Women Living in Urban Slums, Bangladesh," BMC International Health and Human Rights, 11(Suppl. 3): S3. http://www.biomedcentral.com/1472-698X/11/S3/S3. Accessed May 2014.

Rose, L., J. Alhusen, S. Bhandari, K. Soeken, K. Marcantonio, L. Bullock, and P. Sharps. 2010. "Impact of Intimate Partner Violence on Pregnant Women's Mental Health: Mental Distress and Mental Strength," Issues in Mental Health Nursing, 31(2): 103-111.

Singh, S. and R. Samara. 1996. "Early Marriage among Women in Developing Countries," International Family Planning Perspectives, 22 (4): 148-175.

UNDP. 2014. "Human Development Report 2014. "Sustaining Human Progress: Reducing Vulnerabilities and Building Resilience," New York: UNDP.

UNICEF. 2010. "Understanding Urban Inequalities in Bangladesh: A prerequisite for achieving Vision 2021. A study based on the results of the 2009 Multiple Indicator Cluster Survey," Bangladesh: UNICEF.

UNICEF. 2011. “The State of the World's Children 2011. Adolescence: An Age of Opportunity," New York: UNICEF.

UNICEF. 2012. “The State of the World's Children 2012. Children in an Urban World," New York: UNICEF.

World Health Organization (WHO). 2014. "Health for the World's Adolescents: A Second Chance in the Second Decade." http://apps.who.int/adolescent/second-decade/section1. 
